Historic, archived document

Do not assume content reflects current scientific knowledge, policies, or practices. 



$$
82-224-041
$$

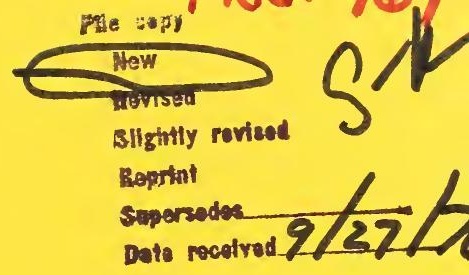

\section{Release and Recovery of \\ Introduced Parasites of the Alfalfa Weevil in Eastern North America}

Production Research Report No. 167

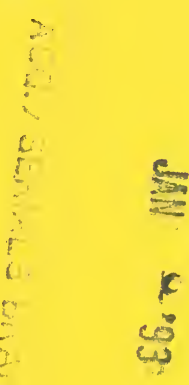

Agricultural Research Service

UNITED STATES DEPARTMENT OF AGRICULTURE 



\section{ACKNOWLEDGMENT}

A large program such as this could not have been accomplished without the assistance of many entomologists. Acknowledgment is made particularly to the staff of the USDA European Parasite Laboratory at Sèvres, France, for providing nearly all the introduced parasites.

A number of staff members of the USDA Beneficial Insects Research Laboratory at Newark, Del., and at its former location in Moorestown, N.J., participated in the work reported here; M. H. Brunson, L. W. Coles, D. W. Jones (deceased), and L. B. Parker furnished the leadership, which resulted in the continuity of the program; E. L. Plasket maintained our extensive record files while at Moorestown. In addition, the technical assistance of S. E. Barth, R. J. Berardy, R. G. Bingham, C. W. Collins, J. R. Coulson, J. J. Drea, R. W. Fuester, T. B. Keepfer, C. Kiem (deceased), B. Puttler, F. A. Streams, J. A. Stewart, and B. R. Witmer is especially appreciated. The two authors have been involved in this program since 1965; R. J. Dysart in Europe during 196571 and since then at Moorestown, N.J., and Newark, Del., and W. H. Day at Moorestown and Newark.

We are particularly indebted to the following State and Federal cooperators for making parasite releases and recoveries and for providing information, not otherwise available to us, about biocontrol work performed in their respective areas: ALABAMA, M. H. Bass; ARKANSAS, F. D. Miner; CONNECTICUT, J. F. Anderson; DELAWARE, P. P. Burbutis; GEORGIA, R. A. White; ILLINOIS, E. J. Armbrust, C. E. White; INDIANA, M. C. Wilson; IOWA, J. R. DeWitt; KANSAS, E. L. Eshbaugh; KENTUCKY, B. C. Pass; MAINE, G. W. Simpson; MARYLAND, C. C. Blickenstaff, J. L. Huggans, J. W. Neal, R. F. W. Schroder, A. L. Steinhauer; MASSACHUSETTS, G. L. Jensen, M. C. Miller; MICHIGAN, T. L. Burger, F. W. Stehr; MINNESOTA, H. C. Chiang; MISSISSIPPI, H. N. Pitre; MISSOURI, B. Puttler; NEBRASKA, G. R. Manglitz; NEW HAMPSHIRE, A. H. Mason, D. W. Sutherland; NEW JERSEY, W. Metterhouse; NEW YORK, G. G. Gyrisco, D. J. Horn, R. L. Richardson, R. Van Driesche; NORTH CAROLINA, W. V. Campbell; OHIO, J. K. Flessel, H. D. Niemezyk; OKLAHOMA, R. C. Berberet; PENNSYLVANIA, A. A. Hower, Z. Smilowitz; SOUTH CAROLINA, C. A. Thomas; SOUTH DAKOTA, R. Rezek, R. J. Walstrom; TENNESSEE, S. E. Bennett (deceased), N. L. Woodiel; TEXAS, L. R. Green, G. Latham, J. G. Thomas; VERMONT, G. B. MacCollom; VIRGINIA, R. D. Hendrick, D. P. Innes, R. L. Pienkowski; WEST VIRGINIA, J. D. Hacker, J. E. Weaver; WISCONSIN, J. W. Apple, M. S. Conrad; CANADA (ONTARIO), J. Abu, C. R. Ellis, J. C. Guppy, J. S. Kelleher, C. C. Loan; (QUEBEC), G. Mailloux, J. G. Pilon. 


\section{CONTENTS}

Purpose and scope

Descriptions of parasites

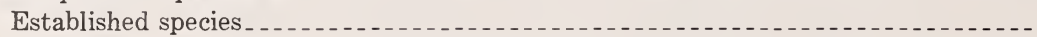

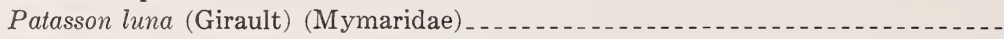

Bathyplectes anurus (Thomson) (Ichneumonidae) .

Bathyplectes curculionis (Thomson) (Ichneumonidae)

Bathyplectes stenostigma (Thomson) (Ichneumonidae) ....................

Tetrastichus incertus (Ratzeburg) (Eulophidae)

Microctonus colesi Drea (Braconidae)

Microctonus aethiopoides Loan (Braconidae)

Species released but not recovered

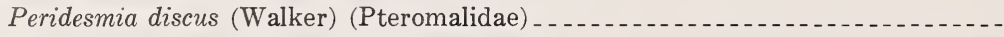

Trichomalus inops (Walker) (Pteromalidae)

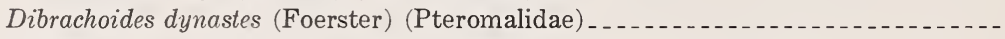

Necremnus leucarthros (Nees) (Eulophidae) .................................

Campogaster exigua (Meigen) (Tachinidae) . . . . . .

Microctonus stelleri Loan (Braconidae)

Other parasitic organisms.

Primary parasites.

Secondary parasites

Methods for release and recovery

Making parasite releases

Sampling for recovery

Timing of collections . .

Rearing cages

A record of parasite liberations and recoveries.

Table 1.-Species released and recovered in Eastern North America, 1957-75 . . . -

Table 2.--Species released in Eastern North America but not recovered, 1957-75_.-Appendix

Table 3.-Partial list of species released in the Western States and their origin, 1957-75_._.

Maps 


\title{
Release and Recovery of Introduced Parasites of the Alfalfa Weevil in Eastern North America
}

\author{
By Richard J. Dysart and William H. Day, research entomologists, Beneficial Insects Research Laboratory, \\ Northeastern Region, Agricultural Research Service
}

The alfalfa weevil (Hypera postica (Gyllenhal)), an introduced pest of European or Eurasian origin, was first detected in Utah in 1904. In 1951, a new invasion of this insect was discovered in Maryland, and this eastern population, hereinafter called "the eastern strain," has gradually moved into all alfalfa-growing areas of Eastern North America. As a result of both infestations, the alfalfa weevil is now in all the 48 contiguous States and in 4 Canadian Provinces. It is considered to be the most important single pest of alfalfa in North America.

\section{PURPOSE AND SCOPE}

In 1957, personnel of the Beneficial Insects Research Laboratory at Moorestown, N.J. (now at Newark, Del.) began inoculative releases of imported parasites against the eastern strain of the alfalfa weevil. The objective of this biological control work is to distribute and establish the exotic natural enemies throughout the range of the eastern strain and thus reduce the weevil population to the approximate level that occurs in Europe. In cooperation with research workers in many States, thousands of releases and recoveries have been made of 13 parasite species in this massive and continuing program.

This publication has three sections. In the first is a brief account of each parasite or predator of the alfalfa weevil that has been established, liberated, or is known to occur in Eastern North America. These descriptions are arranged according to the host stage attacked. In the second are suggested methods for parasite releases and recovery attempts. In the third are listed all releases and recoveries ${ }^{1}$ of introduced parasites on the

'In this report, "recovery" of a parasite species means that it has been collected in the field or reared or dissected from host material obtained from the release site or elsewhere at least 1 year after the release. Survival in the field for this length of time usually indicates that the species has become permanently established in a given area. eastern strain of the alfalfa weevil from 1957 through 1975. In that respect this report is a revision of and a supplement to a previous publication. ${ }^{2}$

This report provides a detailed record of liberations and recoveries so that biocontrol workers will be able to relate colonization efforts in their particular States with those in the surrounding areas. We hope that the release data summarized here will encourage entomologists to search for parasite species that may be successfully established in their areas but that have not yet been recovered.

The geographical region of North America covered in this publication is east of longitude $100^{\circ} \mathrm{W}$. The 100 th meridian was selected because it approximates the point where the eastern and western strains of the weevil converged in 1971. Although the colonization of parasites on the western strain of the alfalfa weevil is beyond the scope of this report, we have listed in the appendix all western releases since 1957 where the parasites were supplied by the U.S. Department of Agriculture.

${ }^{2}$ Brunson, M. H., and Coles, L. W. The introducTION, RELEASE, AND RECOVERY OF PARASITES OF THE ALFAlFA WeEvil IN EAstern United states. U.S. Dept. Agr. Prod. Res. Rpt. 101, 12 pp. 1968. 


\section{DESCRIPTIONS OF PARASITES}

\section{Established Species}

All seven of the introduced and established natural enemies of the alfalfa weevil in Eastern North America are internal hymenopterous parasites of the egg, larva, or adult stage of the weevil. A brief account is given of the colonization, recovery, biology, and habits of each species. Unless otherwise noted, life-cycle data refer to the Middle Atlantic States. Parasitism figures cited are yearly averages for several locations and fields and are percentages of the total, not the peak, host population.

\section{Patasson luna (Girault) (Mymaridae)}

This species previously was placed in the genera Mymar and Anaphoidea and occasionally has been confused with Anaphes pratensis Foerster. P. luna was imported from Italy and released in Utah in 1911-13 and 1925-28. Material from France was also released in California in 1933-34. In all these introductions, $P$. lun $a$ apparently was mixed with $A$. pratensis. The latter was first recovered in 1926 in Utah, but $P$. luna was never recovered in the Western States until recently. ${ }^{3}$

In $1928, A$. pratensis was shipped from Utah to Indiana for release against Hypera nigrirostris (F.), and P. luna might have been included in that material. Although there is no record of a release of P. luna in Eastern North America, in 1958 it was reared from alfalfa weevil eggs collected in Dutchess County, N.Y., by G. O. Poinar of Cornell University. Since then P. luna has been found at about 50 localities in the East (map 1) and is certainly more widely established than is now known.

The adult $P$. luna wasp is $1 \mathrm{~mm}$ long. The female deposits one to two eggs inside a weevil egg and may attack several eggs in a cluster within an alfalfa stem. There are several generations each year, and the parasite passes the winter inside the host egg. P. luna may have other hosts besides the alfalfa weevil. The data available suggest that parasitism by this species averages from 0 to 10 percent in overwintering eggs of the alfalfa weevil.

${ }^{3} P$. luna was reared from alfalfa weevil eggs collected in Cache County, Utah, in 1973 (D. W. Davis, Utah State University, pers. commun.).

\section{Bathyplectes anurus (Thomson) (Ichneumonidae)}

This species has also been referred to as $B$. anura and $B$. corvina. Specimens from Europe were released beginning in 1960, and the species was first recovered in New Jersey and Pennsylvania in 1964. The bulk of the introduced B. anurus was of French origin, although small numbers came from Sicily and the U.S.S.R. By 1966, field populations of $B$. anurus had increased sufficiently at certain release sites in New Jersey and Pennsylvania to permit collections for recolonization in other States. This work is continuing because the natural dispersion of $B$. anurus is slow. It is now well established in 17 Eastern States and in Ontario. Releases and recoveries of $B$. anurus are shown in maps 2 and 3.

The adult wasp is $3 \mathrm{~mm}$ long and has a black, robust body. There is one generation each year. The peak of parasitism occurs about a week before the peak in weevil larvae. The female parasite deposits an egg in the host larva; early instars are preferred. The egg hatches and the parasite larva feeds on the host, killing it after the weevil completes its cocoon. The parasite then spins a hard, brown, football-shaped cocoon, $2 \mathrm{~mm}$ in diameter by $3.5 \mathrm{~mm}$ long, which bears a raised, white, equatorial band. After formation of the cocoon, the parasite larva enters diapause.

The $B$. anurus larva has the unusual ability of causing its cocoon to "jump" several centimeters upward, a trait shared by few other ichneumonid parasites. This mobility increases the survival of $B$. anurus by enabling many cocoons to escape hyperparasites and unfavorable field conditions. The jumping cocoons can be found in plant debris in alfalfa fields.

In the fall the parasite larva pupates, becomes an adult, and diapauses within the cocoon until early the following spring.

In recent years from 6 to 37 percent of weevil larvae have been parasitized by this species in southeastern Pennsylvania and in central and northern New Jersey.

\section{Bathyplectes curculionis (Thomson) (Ichneumonidae)}

This parasite was successfully introduced from 
Italy into Utah in 1911-13 and is now widely distributed in the Western States. In the Eastern United States, releases of $B$. curculionis from Utah were first made in $1953-55$, but these efforts were not successful. In 1959, parasite material obtained from southern California was liberated in Delaware, New Jersey, and Virginia, and in 1960 the species was found to be established in these areas. Although the parental stock of the eastern B. curculionis population is predominantly of Italian origin via California, additional introductions have been made from France, Sweden, and the U.S.S.R. Since its establishment in the East, $B$. curculionis has been widely recolonized by biocontrol workers (map 4), but it has also spread naturally at a phenomenal rate.

It seems certain that this parasite accompanied the alfalfa weevil as it spread from the eastern seaboard into the Midwest and into Canada. B. curculionis has been recorded from more than 750 counties in the East (map 5), and it is probably in every area infested by the eastern strain of the weevil.

$B$. curculionis adults closely resemble those of $B$. anurus, but the female of $B$. curculionis has a longer ovipositor. There is one full generation in the spring, with a peak 1-2 weeks before the host peak, followed by a partial second generation 1-3 weeks after the host peak. Parasite adults are often collected in the summer and fall, especially in the Midwestern States, and these may be the result of a delayed second generation or a partial third or fourth generation.

The female parasite deposits an egg inside the weevil larva, preferring the early instars. The egg may be encapsulated by the host larva's defense reaction, but parasitism is often successful if superparasitism occurs or if the host larva is small when parasitized. Encapsulation of $B$. curculionis eggs by the host often seriously reduces the effectiveness of this parasite. None of the other established parasites are significantly affected. The surviving parasite egg hatches, the larva develops, and it eventually kills the host. The parasite larva then constructs its cocoon inside the weevil's cocoon like $B$. anurus. The cocoons of $B$. curculionis and B. anurus are similar in size and shape, but the white equatorial band of the former is not raised, and the cocoon may be either light brown and flexible (nondiapausing) or dark brown and hard (diapausing). The para- site larva overwinters in the cocoon in the surface litter of alfalfa fields. In the past few years from 5 to 25 percent of weevil larvae have been successfully parasitized by $B$. curculionis in the Middle Atlantic States.

\section{Bathyplectes stenostigma (Thomson) (Ichneumonidae)}

This species has been referred to as Bathyplectes sp. "bagged," because the cocoon resembles a brown paper bag. It has also been referred to as $B$. contracta. Almost all the B. stenostigma released in North America were of Swedish origin; a few lots were from France. Liberations began in 1964, and large numbers were released at many localities in 1968 and 1969 (map 6). The species was first recovered in 1970, but it has been difficult to establish and has dispersed little. To date it has been recovered at only seven release sites in the East (map 7).

The adult parasite resembles the two previous species of Bathyplectes, except it is predominantly dark brown and the body is less robust. There is one generation per year, with the peak of parasitism occurring 1-2 weeks after the host larval peak. The female parasite lays an egg in a weevil larva. After hatching, the parasite larva develops, eventually killing the host before the latter spins a cocoon. Thus, the $B$. stenostigma cocoon, which is $3.8 \mathrm{~mm}$ long with no external white band, is constructed in the soil litter, where the parasite larva spends the winter in diapause. In a field near Hadley, Mass., during 1974 and 6 years after release, $B$. stenostigma parasitized over 7 percent of the total population of weevil larvae.

\section{Tetrastichus incertus (Ratzeburg) (Eulophidae)}

A few authors have called this species T. erdoesi. Releases of T. incertus began in 1960, and in 1962 it was found to be established in parts of Delaware, Maryland, New Jersey, and Pennsylvania. By 1964, field populations of $T$. incertus were being used as sources of recolonization in other States. Releases of this species are shown in map 8 .

The established parasites were from a single locality in southern France; however, from 1967 to 1973 , additional small introductions were made from Sweden, Romania, and Yugoslavia to enlarge the gene pool. The parasite dispersed very rapidly during the 1960 's, but its movement has 
greatly decreased in recent years. It is now present in 16 Eastern States and in Ontario and Quebec (map 9).

The adult is $1-1.5 \mathrm{~mm}$ long, black, compact rather than narrow and wasplike. There are three to four generations per year, with the largest populations in July-September. The female oviposits while astride a weevil larva, laying several eggs inside. From four to seven of the resulting parasite larvae complete development, killing the weevil larva after it has spun its cocoon. The parasites pupate within the empty skin of the host, which turns a mahogany brown and becomes brittle after the death of the host larva. Winter is spent in the prepupal stage within the host "mummy."

During July, August, and September of 1965-69, T. incertus parasitized from 50 to 80 percent of weevil larvae in New Jersey and the surrounding States, but in recent years the species has been much less abundant. This is a direct result of the much lower levels of alfalfa weevil larvae, especially during the summer and fall. This in turn is a result of the pressure exerted by this and the other parasite species that are abundant in the Middle Atlantic region.

\section{Microctonus colesi Drea (Braconidae)}

Before it was named in 1968, this species was ?ferred to as Microctonus sp. "black" or "domestic clack." It was first found in 1962 in southeastern Pennsylvania, although it had never been released. Since there is no evidence to suggest that $M$. colesi is native or had gained entrance prior to the alfalfa weevil, it is treated here as an introduced parasite. Probably it entered this country within the weevil. Because $M$. colesi is parthenogenic, establishment could have resulted from a small number of individuals. $M$. colesi is now known to be present in 13 Eastern States and appears to be moving slowly westward, considerably behind the weevil. Releases and recoveries of $M$. colesi are shown in maps 10 and 11.

The adult $M$. colesi is wasplike, $3 \mathrm{~mm}$ long, and entirely black. All individuals are female, and there is one generation per year. The period of oviposition roughly coincides with the larval peak of the alfalfa weevil. The egg is laid inside the weevil larva; the larger instars are preferred. After hatching, the first-instar larva enters dia- pause and remains so while the host pupates and becomes an adult. The parasite larva overwinters within the adult weevil. During the following spring the parasite larva matures, kills the weevil, and spins a white cocoon in the soil litter. Since the fertility of weevils containing $M$. colesi larvae is much reduced in male weevils or eliminated in females, this effect is in addition to the ultimate mortality. From 1969 to $1973, M$. colesi parasitized from 1 to 18 percent of the "new" (newly emerged, sexually immature) weevils in the Middle Atlantic region.

\section{Microctonus aethiopoides Loan (Braconidae)}

For many years this parasite has been referred to as $M$. aethiops; in fact, this name has been used in practically all the North American literature. Recently, however, Loan decided that the name $M$. aethiops had been misapplied, and he described the parasite discussed here as $M$. aethiopoides. ${ }^{4}$

This species was first released against the alfalfa weevil in 1957 and was found to be established in 1961 in New Jersey. All introduced parasites were from France. In 1963, field collections were begun in New Jersey for shipment to and release in other States. This recolonization has continued through 13 seasons. As a result of both recolonization and natural dispersal, $M$. aethiopoides is now present in 14 Eastern States and in Ontario (maps 12 and 13).

The adults are wasplike and $3 \mathrm{~mm}$ long; females are red brown and males are black. There are two generations per year. In the spring, about the time of the host larval peak, the female lays a single egg inside many of the "old," overwintered sexually mature weevils. After hatching, the $M$. aethiopoides larva matures, issues from the dying host, and forms a white, silky cocoon, $4 \mathrm{~mm}$ long, in the soil litter. After pupation for 2-3 weeks, the adult parasite emerges from the cocoon. The female parasite oviposits in a "new" sexually immature adult weevil, and the resulting parasite larva diapauses and overwinters in the first instar within the weevil adult. Early the next spring the larvae of $M$. aethiopoides complete their development, spin cocoons, and transform to adults.

$M$. aethiopoides kills from 70 to 90 percent of the overwintered weevils in the Middle Atlantic

${ }^{4}$ LOAN, C. C. A REVIEW OF HALIDAY SPECIES OF MICROCTONUS (HYM.: BRACONIDAE, EUPHORINAE). Entomophaga 20:31-41. 1975. 
States, and the second generation parasitizes an average of 7 to 39 percent of the new weevils. Even though the parasitized new weevils are not killed until the following spring, all the females and many of the males are rendered sterile, so the control impact is even more significant. Many biocontrol workers in the East consider $M$. aethiopoides the most important single species in the weevil parasite complex.

\section{Species Released but not Recovered}

Five of the species discussed here are small Hymenoptera and one is a tachinid fly. These insects were released in Eastern North America during 1957-72 but were never recovered. Possibly a few species are established in certain areas, because many releases have not been followed by surveys adequate for detection. It is hoped that the information provided here, plus the tables and maps, will encourage further searching for these species.

\section{Peridesmia discus (Walker) (Pteromalidae)}

This species, previously called $P$. phytonomi, was obtained in southern France and was released from 1959 through 1972. More than 45,000 adults were liberated in the East, mainly in the Southern States (map 14).

The adult is a black, compact wasp, $2 \mathrm{~mm}$ long. The female punctures the alfalfa stem with her ovipositor and lays an egg on the weevil egg mass. The larva feeds externally as a predator on the host eggs. Pupation occurs within the stem cavity. There are several generations per year, but because few weevil eggs are present in the summer and early fall, it is likely that $P$. discus passes this period in diapause or on an alternate host. The adults can live for many months and are very hardy. In southern France the adults oviposit in the field from November through January. Extensive surveys in France indicated that this predator was present in 6 percent of the overwintering egg masses.

\section{Trichomalus inops (Walker) (Pteromalidae)}

Ten releases were made of this species in the East from 1959 to 1970 (map 15). It was collected in France along with $P$. discus, but it was much less abundant. Both species are similar in size, appearance, and life cycle as far as is known. In Europe T. inops is also thought to attack the eggs of Apion sp.

\section{Dibrachoides dynastes (Foerster) (Pteromalidae)}

This species has also been referred to as $D$. druso. From 1959 to 1964 , over 13,000 D. dynastes adults of French origin were released at 28 localities in the Eastern States (map 16). The buik of the released material was reared in the Moorestown laboratory. Although it has never been recovered in the East, in 1967 it was established in San Diego County, Calif., by entomologists of that State.

$D$. dynastes is a parasite of prepupae and pupae of the alfalfa weevil. The adult parasites are 2-3 mm long, with a metallic-green head and thorax. There are two generations per year in southern France, and the parasite apparently overwinters as an adult. Several eggs are laid on the host prepupa or pupa within its cocoon. After hatching, the parasite larvae feed externally on the body of the host. Usually three to five parasites reach maturity. In Europe this species also attacks other species of Hypera.

\section{Necremnus leucarthros (Nees) (Eulophidae)}

This species was released in 1965 at only two localities in New Jersey (map 17). About 300 adults of Italian origin were liberated at each site.

Like the preceding species, $N$. leucarthros is a gregarious ectoparasite of weevil prepupae. The adult parasites are 1.5-2.3 $\mathrm{mm}$ long and metallic green. The males possess branched antennae. In Europe $N$. leucarthros is widely distributed and attacks several species of Coleoptera, including other Hypera.

\section{Campogaster exigua (Meigen) (Tachinidae)}

During 1957, three small releases of this fly were made in Delaware and New Jersey (map 18). A total of 168 adults from France were liberated.

The adults are about $2.5 \mathrm{~mm}$ long and dark gray. The female does not lay eggs but deposits a first-instar larva on the thorax of the adult weevil. After penetrating the host, the parasite larva develops and finally forms a brownish puparium within the body of the weevil. The number of generations per year is not known; however, in the laboratory one complete generation requires 
from 48 to 70 days. In Europe C. exigua also attacks several species of Sitona.

\section{Microctonus stelleri Loan (Braconidae)}

Before it was named in 1972, this species was referred to as Microctonus sp. "European black." From 1968 to 1970 , over 4,100 adults obtained in France were released at 23 localities in the Eastern States (map 19).

The parasite has one generation per year, and its only known host is the alfalfa weevil. The females of $M$. stelleri and $M$. colesi are very similar in size and appearance. However, $M$. colesi is unisexual (all individuals are female), whereas $M$. stelleri has both sexes in about equal proportion. In the spring the mature parasite larva issues from the overwintered adult weevil and forms a white cocoon about $4 \mathrm{~mm}$ long in the ground litter. In about 2 weeks the adult parasite emerges, mates, and oviposits in larvae of the alfalfa weevil. It prefers larger instars. The parasite egg hatches, the first-instar larva enters diapause, and it remains so while the host pupates and becomes an adult. The $M$. stelleri larva overwinters within the adult weevil. Extensive collections in northern France during 1966-70 indicated that about 5.6 percent of the overwintering weevils were parasitized by $M$. stelleri.

\section{Other Parasitic Organisms}

\section{Primary Parasites}

Included here are various natural enemies that have been recorded from the eastern strain of the alfalfa weevil. These species are native to North America, and most of them attack a variety of other hosts. On the alfalfa weevil their control impact is almost always of minor significance. No doubt additional adventitious parasite species will be discovered.

Fidiobia rugosifrons Crawford (Platygasteridae).-In 1972, adults of this species were reared from overwintering weevil eggs in Ontario. Curiously the parasite has not been recorded from weevil eggs at any other eastern site, although its type locality is in Pennsylvania.

Hexamermis arvalis Poinar and Gyrisco (Mermithidae).-This nematode is most often found in fourth-instar weevil larvae, but pupae and adults are also parasitized. A single weevil may contain from one to three nematodes. When mature, these nematodes are often more than 9 $\mathrm{cm}$ long. The weevil larvae die soon after issuance of the nematodes. This species has been reported from several other insect families.

Several adventitious parasites have been reared from weevil pupae at a few localities in the East: Eriplanus micator (Gravenhorst) (Ichneumonidae), Helicobia rapax (Walker) (Sarcophagidae), Itoplectis conquisitor (Say) (Ichneumonidae), Pediobius sp. (Eulophidae), and Spilochalcis albifrons (Walsh) (Chalcididae). The last species is usually a hyperparasite, attacking Bathyplectes cocoons. See discussion of secondary parasites.

Hyalomyodes triangulifer (Loew) (Tachinidae).-This fly is $3.5 \mathrm{~mm}$ long and has been reared from adult weevils collected in the field during the fall, winter, and spring. It is widely distributed in the East and parasitizes many species of adult Coleoptera. It has been recorded from the alfalfa weevil from New York to Georgia. After it issues from the dead host, the fly larva forms a small, brown puparium on the soil. The life cycle is probably similar to that of Microctonus aethiopoides. In certain eastern localities $H$. triangulifer has occasionally been found in as many as 5 percent of the weevils.

Leucostoma simplex (Fallén) (Tachinidae).This fly was reared from an adult weevil collected in Dutchess County, N.Y. L. simplex is apparently Holarctic in distribution.

In addition, several diseases attack the alfalfa weevil. Microsporidian diseases, caused by species of Nosema and Perezia, are common in laboratory cultures, but they are rarely found in the field. Fungus diseases are also known. Those caused by species of Beauveria and Entomophthora are most frequently observed in nature. Epizootics caused by $E$. phytonomi Arthur have been reported in Ontario during the past few years.

\section{Secondary Parasites}

Members of this group, commonly known as hyperparasites, are not parasitic on the alfalfa weevil, but they attack the natural enemies of the weevil instead. They are discussed here only because they will be encountered in parasite impact studies and may be confused with the pri- 
mary parasites. Competent identification is, therefore, necessary in such investigations.

Because Bathyplectes spp. spend many months in cocoons exposed on the soil, they are especially vulnerable to attack by secondary parasites. The following nine hymenopterous species have been reared from cocoons of Bathyplectes spp. in Eastern North America. This list does not include a few species that have been reared infrequently from Bathyplectes, and certainly additional hyperparasites will be recorded if there are more intensive field investigations.

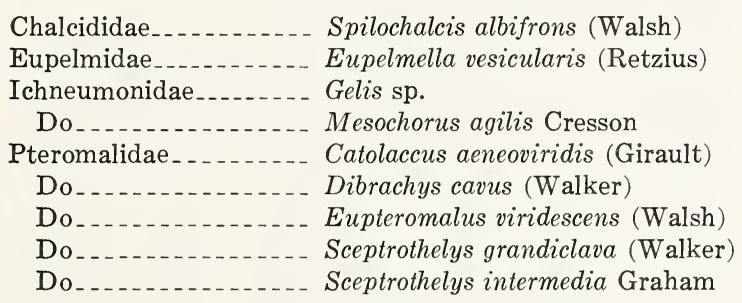

All these species, except $M$. agilis, lay their eggs inside the Bathyplectes cocoon; $M$. agilis oviposits in weevil larvae previously parasitized by Bathyplectes. S. albifrons, E. vesicularis, Gelis sp., $M$. agilis, and $C$. aeneoviridis are solitary parasites, i.e., only one adult is produced per Bathyplectes cocoon. D. cavus, E. viridescens, $S$. grandiclava, and $S$. intermedia are normally gregarious. Some unusual morphological features should be noted. Adults of Gelis sp. are always female and wingless, and females of $E$. vesicularis have greatly abbreviated wings. Adults of S. albifrons have conspicuously enlarged hind femora.

The mummies of Tetrastichus incertus remain on the soil for many months and, like cocoons of Bathyplectes, are particularly exposed to attack by hyperparasites. However, no secondaries are known to have been recorded from $T$. incertus mummies in this country. Similarly no hyperparasites have been recorded from cocoons of Microctonus, perhaps because they are in the soil litter for only a few weeks. However, the absence of hyperparasite records for these mummies and cocoons may only reflect the limited sampling efforts. On the other hand, we seriously doubt that hyperparasites will be found on the larval stages of Microctonus and Tetrastichus within their hosts, since none have ever been detected in extensive dissections and rearings over a 10 -year period at this laboratory.

\section{METHODS FOR RELEASE AND RECOVERY}

\section{Making Parasite Releases}

Several requisites are critical for the successful establishment of parasites. The alfalfa field selected should have at least a moderate population of alfalfa weevils; the stage of the host should be appropriate (e.g., larvae for T. incertus); and insecticides should not be applied for at least 4 weeks or 1 year or more when possible. Previously mated females or mixtures of male and female parasites are suitable for release. The carton containing the parasites should be placed at the base of the alfalfa plants near the center of the field and opened slightly. If foliage is then arranged over the opening, the parasites will be less likely to disperse widely. After about 5 minutes the container can be examined, and the number and sex of the parasites that died in transit can be determined. It is imperative that parasites be released in the field as soon as possible after receipt.

After a parasite has become well established at a release site, workers in some States have made recolonization releases within their States to accelerate parasite dispersal. Either parasitized hosts are collected and released directly in a different county, or the adult parasites are first obtained through rearing and then released. In certain States parasite recolonization efforts have been very successful.

\section{Sampling for Recovery}

We have found that the number of parasite species attacking the alfalfa weevil in a given area is frequently much greater than had been suspected. Careful surveys are required to determine whether a species has become established at a release site or whether parasites have dispersed from another area. Such surveys are based on (1) field collection of adult parasites, (2) dissection of field-collected hosts, or (3) rearing of parasites from field-collected hosts. Although the first two 
methods are extremely useful, they require considerable experience on the part of the collector; they will not be discussed here.

The rearing method begins by collecting the appropriate host stage in the field at the right time. These hosts are placed in the proper type of cage in the laboratory and are provided with adequate food. This should result in parasite adults, cocoons, or mummies, which can then be identified.

\section{Timing of Collections}

Egg parasites.-All parasite species that feed internally in the egg or externally on the egg mass can be recovered whenever weevil eggs are present in the field, but the most profitable period is probably during the winter. Alfalfa stems containing weevil eggs should be cut in the field and taken to the laboratory for examination.

Larval parasites. - To provide estimates on timing that will be usable in different climatic regions, it is necessary to relate these estimates to a common biological reference point. The time of the host larval peak or maximum population density in the spring is used here for this purpose. In order to recover the following parasites, host larvae should be collected throughout the periods indicated: Bathyplectes anurus, 14 days prior to the host larval peak; $B$. curculionis, 14 days prior to and 14 days following the larval peak; $B$. stenostigma, from the larval peak to 21 days following the peak; Tetrastichus incertus, from the larval peak through the summer and fall if larvae are present.

Pupal parasites.-All species that attack the pupal stage of the alfalfa weevil can be recovered by collecting host cocoons whenever they are most abundant in the field. Depending on locality, this should be about 1-3 weeks after the host larval peak.

Adult parasites.-To recover any of the three species of Microctonus, host adults can be collected during midwinter or when they first appear in the spring. Probably the most profitable time to recover $M$. aethiopoides from overwintered host adults is from the host larval peak to 21 days thereafter. Hyalomyodes triangulifer can be recovered at this time and also later in the season. In addition, certain workers have successfully used topical applications of synthetic hormones, such as epoxyfarnesenic acid compounds, on new weevil adults to force emergence of parasites.

\section{Rearing Cages}

Egg parasites.-Alfalfa stems can be split to locate weevil egg masses. Eggs can be either left in place in short sections of stem or removed and incubated in small vials, capsules, or petri dishes. Moist filter paper or plaster-of-paris will maintain humidity. Recoveries also can be made by incubating bulk collections of alfalfa stems in darkened emergence chambers and collecting all adult insects attracted to a light source.

Larval parasites.-When attempting recovery of parasites, it is best to collect fourth-instar weevil larvae from the field. Such larvae will have been exposed to parasite attack for the longest time and will require a shorter rearing period in the laboratory. They can be reared in any plastic, wood, or cardboard cage if it (1) is ventilated with two screened side openings, (2) is constructed to prevent escape of the hosts and any parasites that emerge, and (3) contains fresh alfalfa bouquets as food. Another useful technique is to place larvae in large paper bags (up to 2,500 larvae per bag) with a quantity of alfalfa foliage. The bags are cut to a height of $25 \mathrm{~cm}$ and the tops left open for ventilation. Weevil larvae remain below with the foliage and do not escape from the bag. Small amounts of fresh alfalfa are added twice each day until the weevil larvae begin to spin cocoons. Then the tops of the bags are closed securely, and the bags are stored in a dry, well-ventilated area for several weeks, after which the parasite cocoons can be removed and counted.

Pupal parasites.--Species that emerge from the pupal stage can be recovered by collecting intact weevil cocoons from ground litter and the lower foliage in alfalfa fields. The host cocoons should be placed individually in small vials or gelatin capsules. By collecting and isolating weevil cocoons in this manner, investigators will obtain not only pupal parasites but many primary larval parasites and their secondaries as well. However, Bathyplectes stenostigma cannot be recovered by this method because it normally kills the host larva before the latter spins a cocoon.

Adult parasites.-To rear parasites from the adult weevil, best results are obtained when weevils are fed alfalfa bouquets in a small, venti- 
lated cage with a false screen bottom of about 16 mesh per inch. The parasite larvae will issue from the weevils, pass through the screen, and pupate on the cage bottom under felt strips placed on absorbent paper. Parasite cocoons or puparia should be removed weekly without tearing the fragile cocoons and held in vials for emergence of adults. Since the larva of Campogaster exigua forms its puparium within the body of the adult weevil, examination of the dead weevils in the cage would be necessary to detect it.

Parasites can be identified by sending the adults to the Systematic Entomology Laboratory, ARS, USDA, ARC-West, Beltsville, Md. 20705.

\section{A RECORD OF PARASITE LIBERATIONS AND RECOVERIES}

The seven parasite species presently established in Eastern North America are listed in table 1. Parasite release and recovery information is tabulated alphabetically by species, State, and county, and the locality or the name of the nearest town is given. The year of first recovery in a county is shown in the last column. Many of the releases in table 1 are recolonization releases made by various State workers. Where a parasite has been recovered in a particular State, release and recovery data are presented only on a county basis for that State. It is assumed that biocontrol workers will be able to find specific parasite populations within these counties for purposes of recolonization.

Many individual species have been recovered in counties where the parasite was never released. These records are, of course, the result of natural dispersion. Recoveries in a given field during the same season of release are not included here unless the recovery was made prior to the release. Therefore, the recovery records indicate that a species has survived at least one winter in the field.
The six species released in Eastern North America but not recovered are listed in table 2 . As is often the case, the reasons for the failure of these parasites to become established are not known. Unfortunately, attempts to recover introduced species have varied greatly. In a few instances it is still too early to determine whether a species is successfully established or not.

The information on parasite liberations and recoveries has been collected from several sources, including release records on file at the Beneficial Insects Research Laboratory, release and recovery work by our laboratory staff, publications and proceedings of meetings and conferences, and inquiries to individual Federal and State workers. (See cooperators listed under Acknowledgment.)

Certain release information in tables 1 and 2 differs from that in Production Research Report 101, and the present data should be used.

A partial list of parasite releases in the Western States is in table 3 (Appendix).

TABLE 1.-Species released and recovered in Eastern North America,,$^{1} 1957-75$

\begin{tabular}{|c|c|c|c|c|}
\hline $\begin{array}{l}\text { Species released } \\
\text { and State }\end{array}$ & County & Locality & $\begin{array}{l}\text { Year of } \\
\text { release } \\
(19-)\end{array}$ & $\begin{array}{l}\text { Year of } \\
\text { first } \\
\text { recovery } \\
(19-)\end{array}$ \\
\hline
\end{tabular}

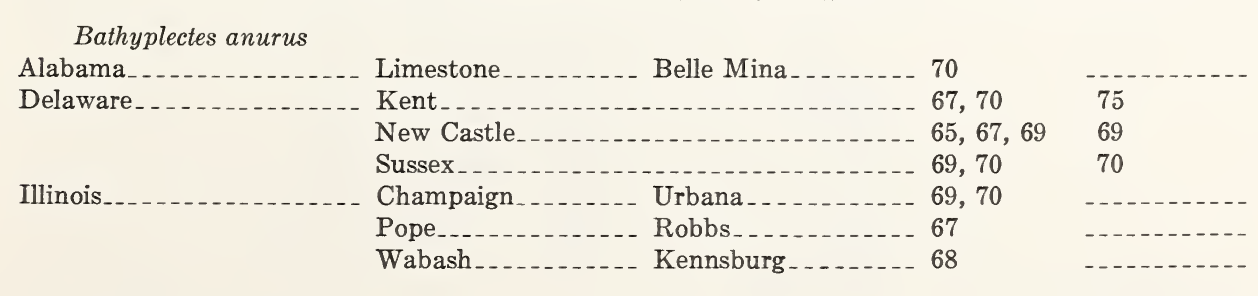


TABLE 1.-Species released and recovered in Eastern North America, ${ }^{1}$ 1957-75-Con.

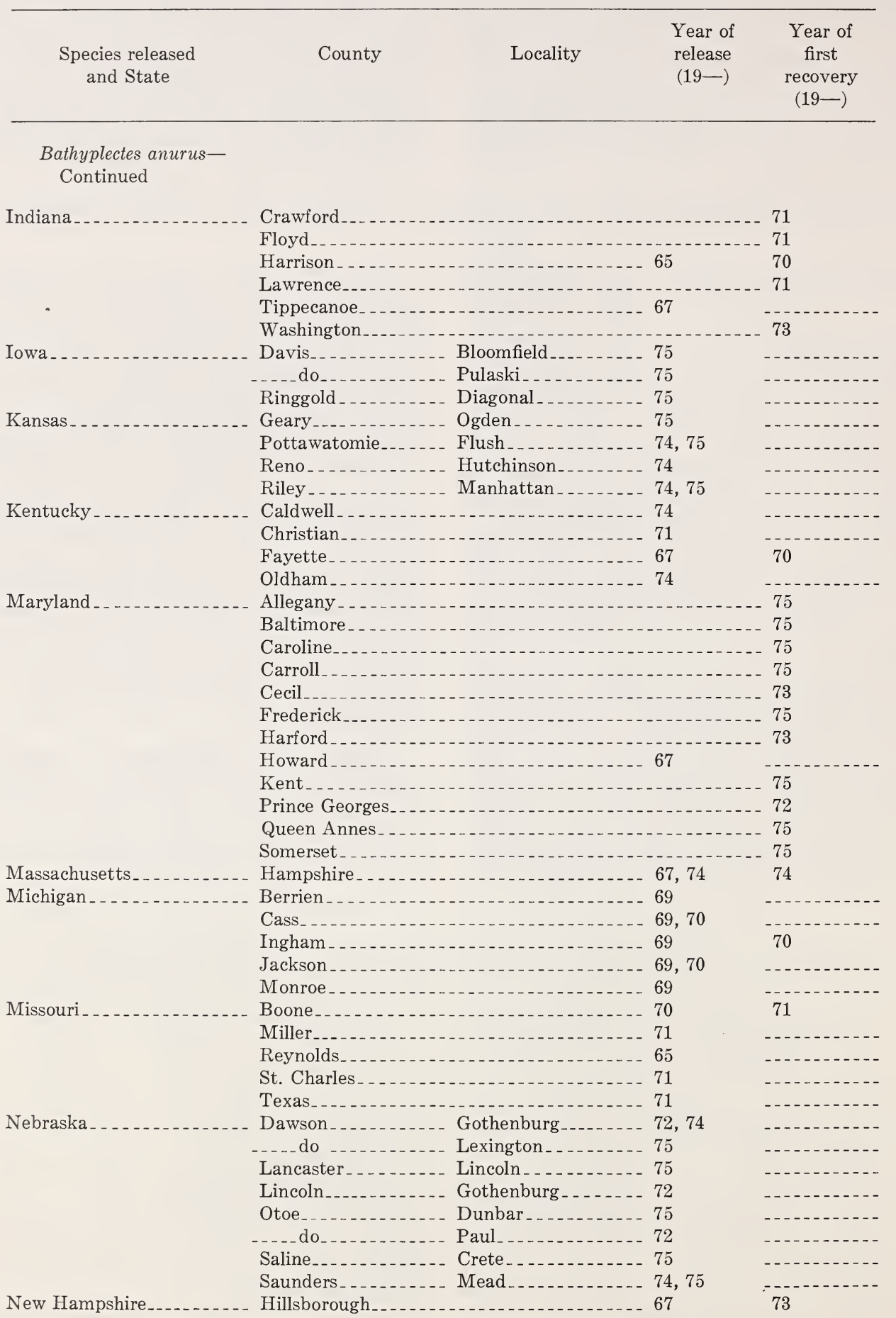


TABLE 1.-Species released and recovered in Eastern North America, ${ }^{1}$ 1957-75-Con.

\begin{tabular}{|c|c|c|c|c|}
\hline $\begin{array}{l}\text { Species released } \\
\text { and State }\end{array}$ & County & Locality & $\begin{array}{l}\text { Year of } \\
\text { release } \\
(19-)\end{array}$ & $\begin{array}{l}\text { Year of } \\
\text { first } \\
\text { recovery } \\
(19-)\end{array}$ \\
\hline
\end{tabular}

New Jersey

Burlington

$60,63,66 \quad 64$

Camden

Cumberland . . . . 66

66

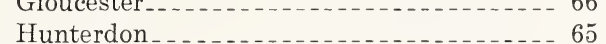

Mercer

Middlesex

Monmouth . . . . . .

-

75

Ocean

Salem

Somerset.

Sussex

New York _...

Dutchess

Franklin ...

Herkimer.... $71 \quad 72$

Orange

Tomkins _.

North Carolina

Wayne

Ashe

Rowan

Wake

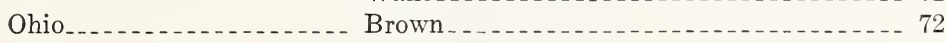

Clark

Clinton.

Erie

Franklin . . .

Henry _. . . . . . . . . . . . . . . . . 75

Mahoning _.

Pickaway_.._.

Putnam

Warren

Wayne_...

Wood

Oklahoma

Grady . . . . .

Kiowa . . . . . . . . . 75

Payne

Stephens_...

Washita_...

Pennsylvania _. . . . . . Berks

Carbon

Chester. . . .

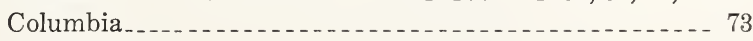

Cumberland . . .

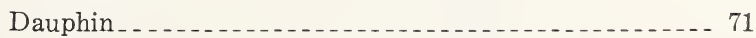

Delaware

Franklin - . . .

Fulton.

See footnotes at end of table. 
TABLE 1.-Species released and recovered in Eastern North America, ${ }^{1}{ }^{1957-75-C o n}$.

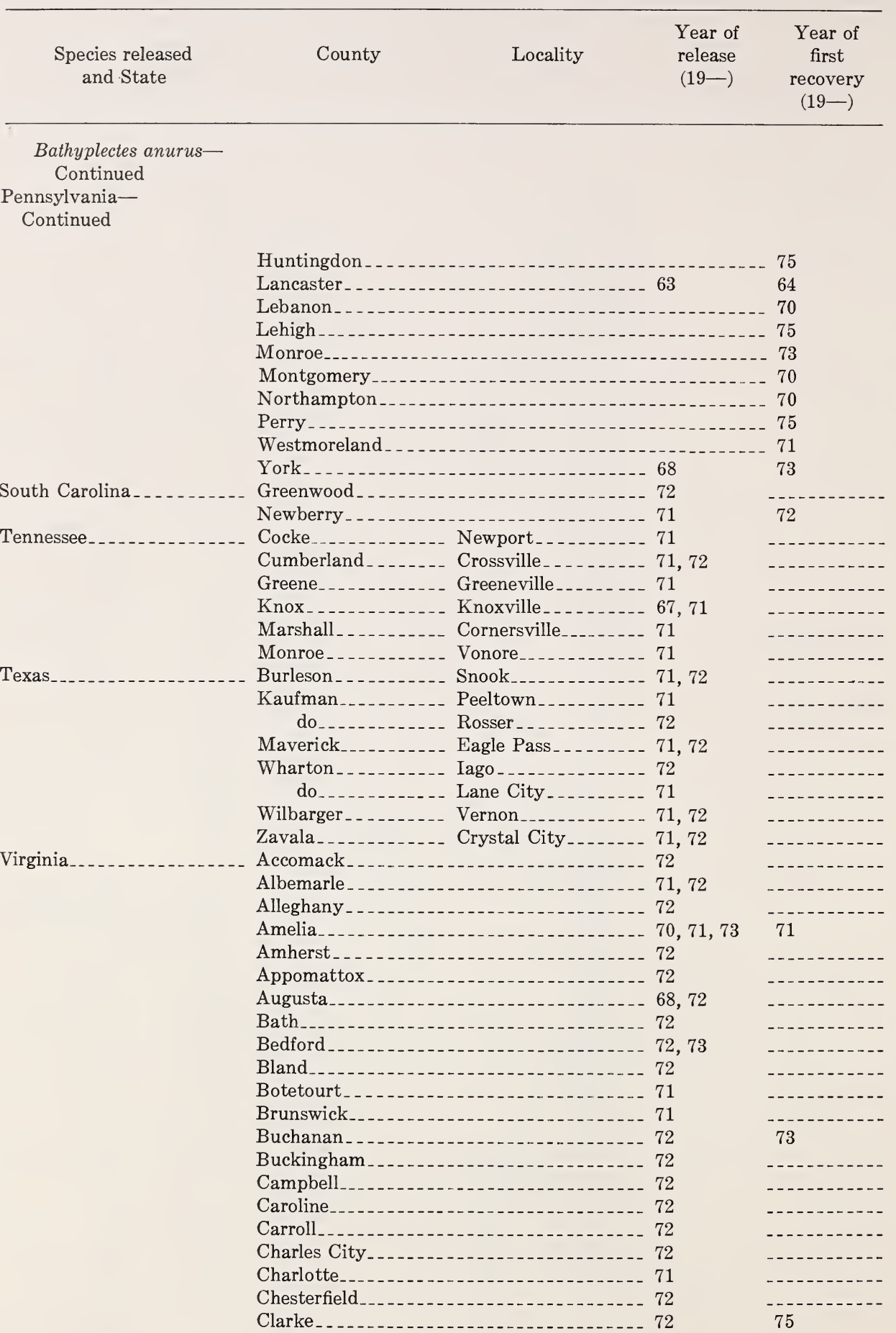


TABLE 1.-Species released and recovered in Eastern North America, ${ }^{1} 1957-75-C o n$.

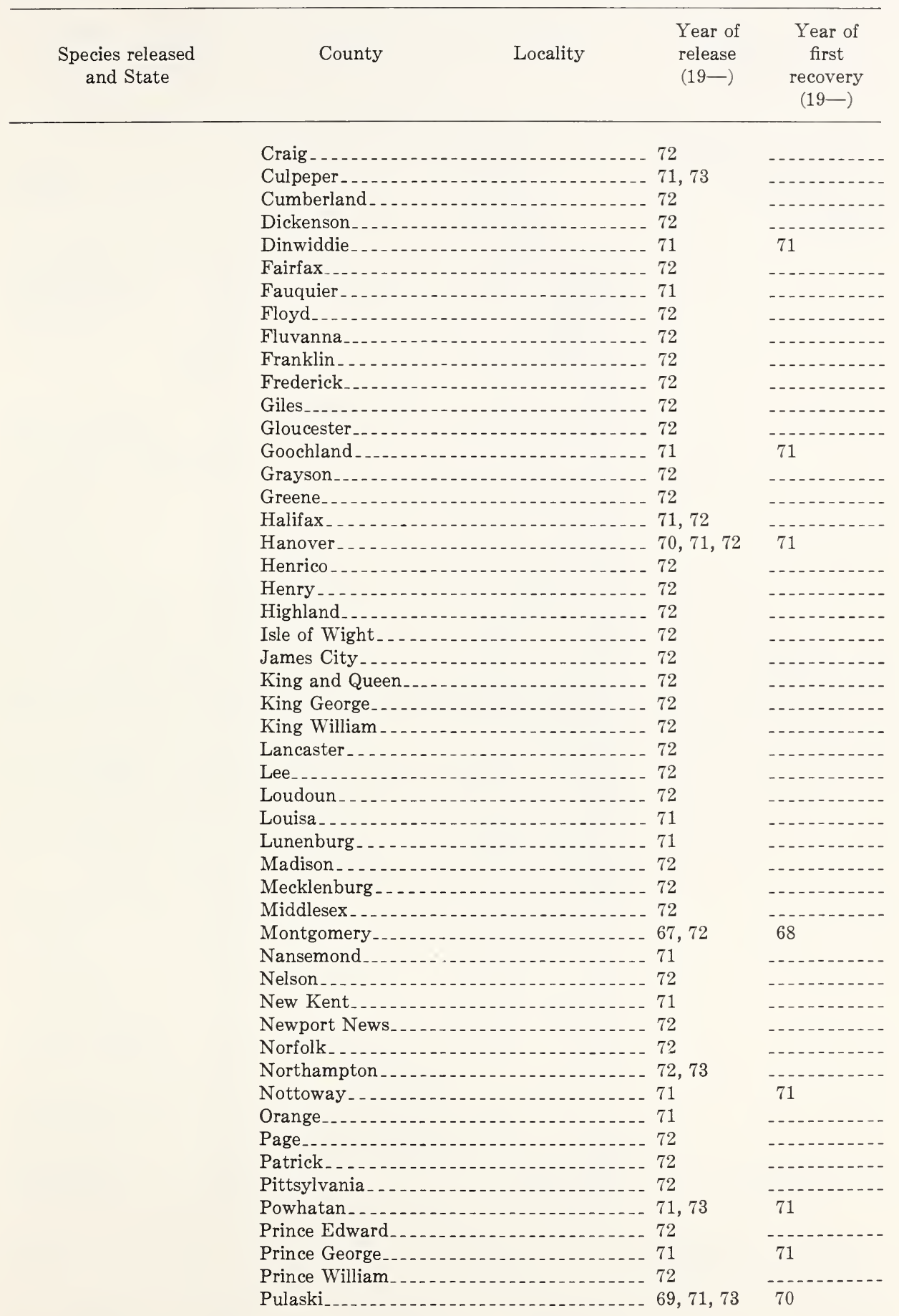


TABLE 1.-Species released and recovered in Eastern North America, ${ }^{1}{ }^{1957-75-C o n}$.

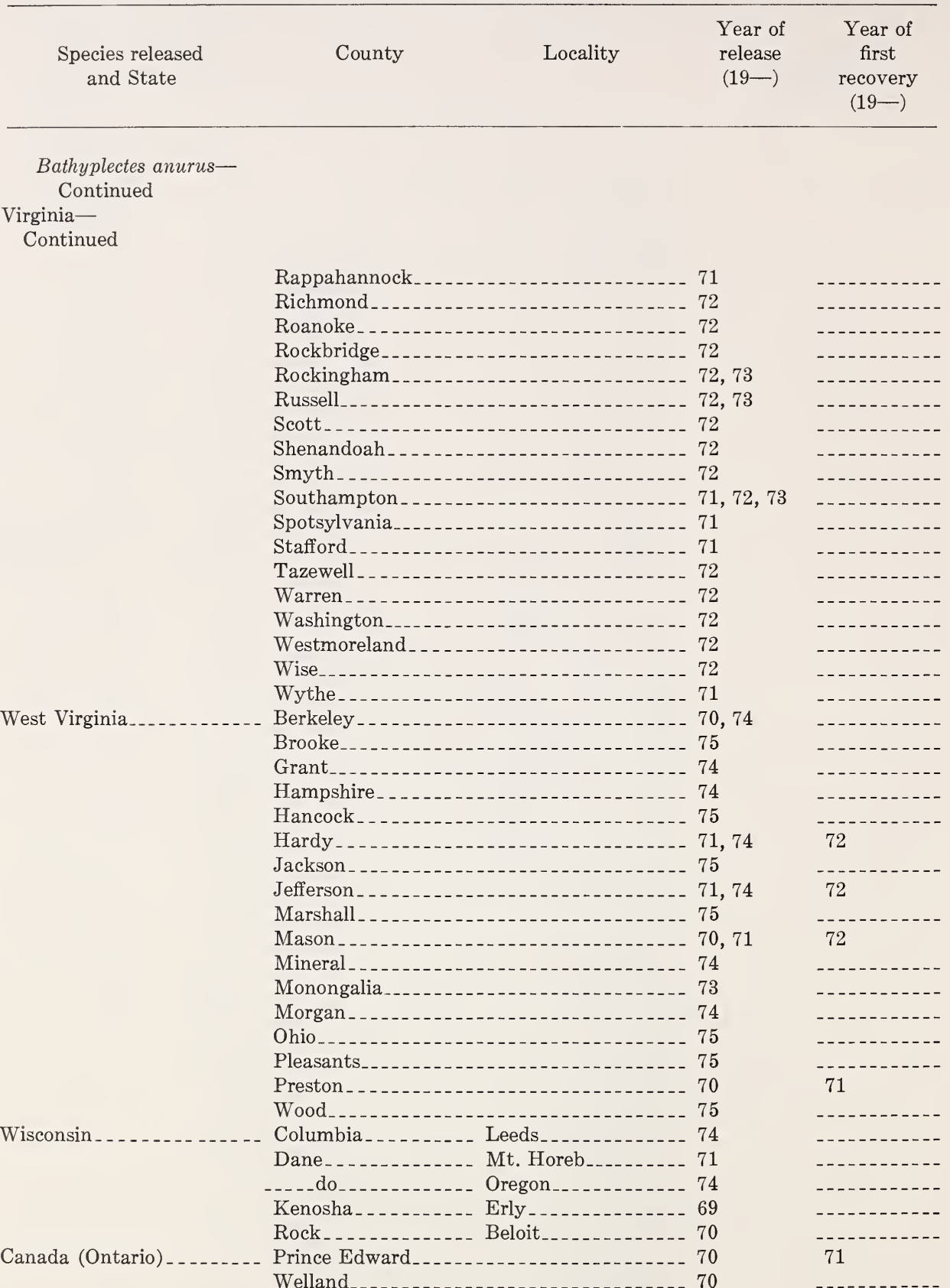

Bathyplectes curculionis ${ }^{2}$

Bathyplectes stenostigma ${ }^{3}$ Delaware. 
TABLE 1.-Species released and recovered in Eastern North America, ${ }^{1} 1957-75$-Con.

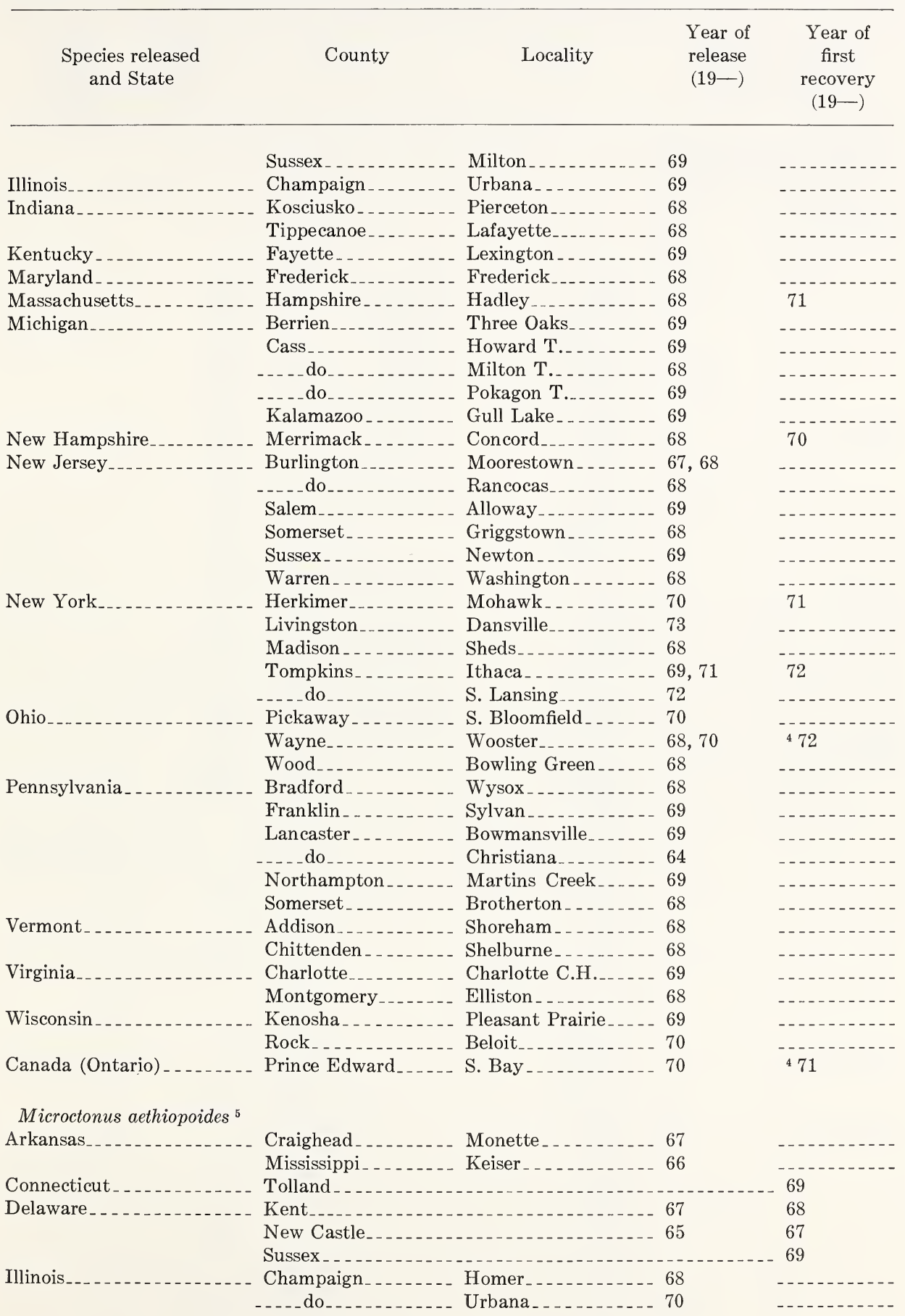


TABLE 1.-Species released and recovered in Eastern North America, ${ }^{1} 1957-75-C o n$.

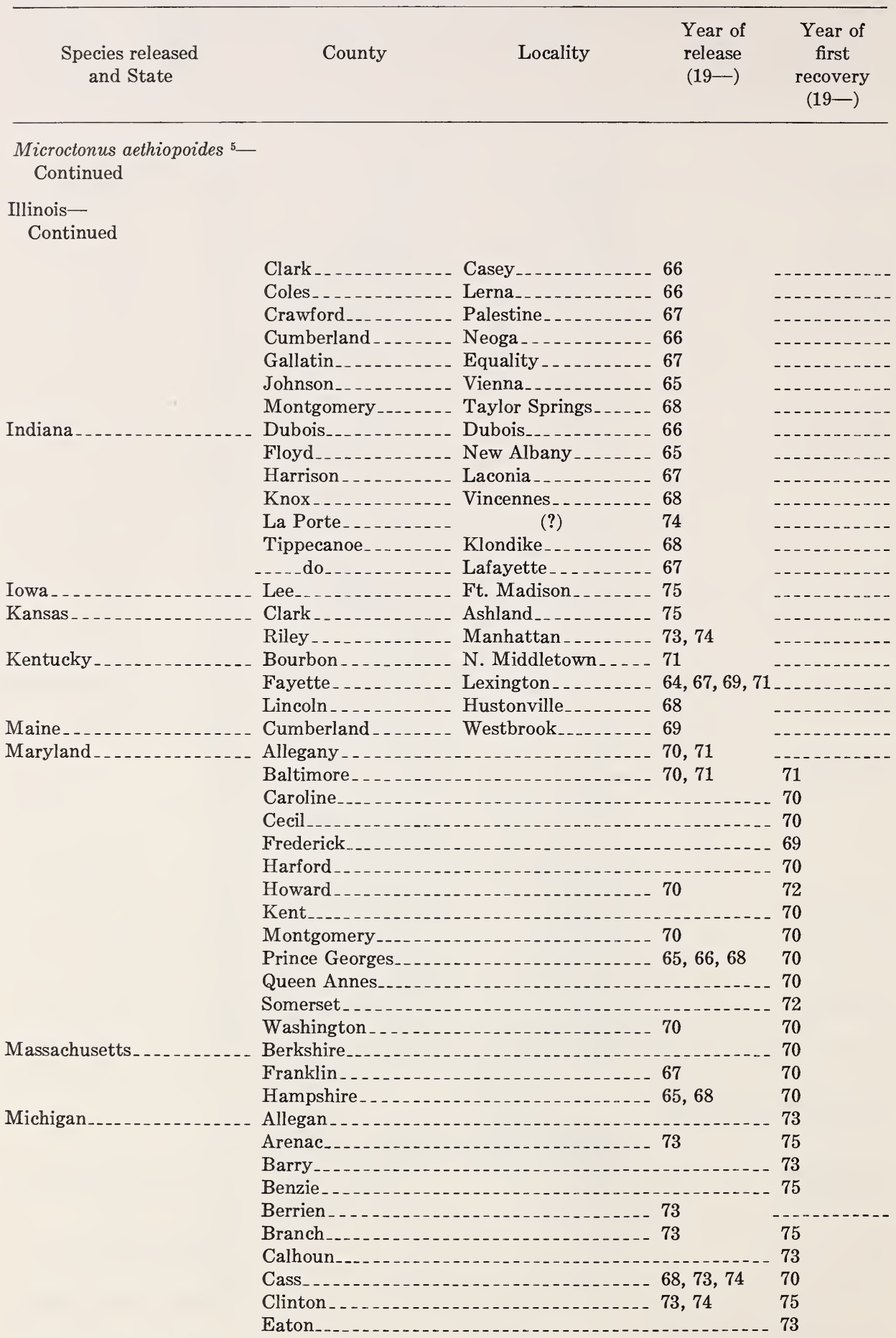


TABLE 1.-Species released and recovered in Eastern North America, ${ }^{1} 1957-75-C o n$.

\begin{tabular}{|c|c|c|c|}
\hline $\begin{array}{l}\text { Species released } \\
\text { and State }\end{array}$ & Locality & $\begin{array}{l}\text { Year of } \\
\text { release } \\
(19-)\end{array}$ & $\begin{array}{l}\text { Year of } \\
\text { first } \\
\text { recovery } \\
(19-)\end{array}$ \\
\hline & \multicolumn{3}{|c|}{ Hillsdale $\ldots$} \\
\hline & \multicolumn{2}{|c|}{ Ingham . } & 72 \\
\hline & \multicolumn{2}{|c|}{ Ionia } & 75 \\
\hline & \multicolumn{2}{|c|}{ Isabella } & 75 \\
\hline & \multicolumn{2}{|c|}{ Jackson } & 70 \\
\hline & \multicolumn{2}{|c|}{ Kalamazoo } & 70 \\
\hline & \multicolumn{2}{|c|}{ Kent } & $-\ldots$ \\
\hline & \multicolumn{2}{|c|}{ Lake } & 75 \\
\hline & \multicolumn{2}{|c|}{ Lapeer.1. } & 75 \\
\hline & \multicolumn{2}{|c|}{ Lenawee. } & 75 \\
\hline & \multicolumn{2}{|c|}{ Livingston } & 75 \\
\hline & \multicolumn{3}{|c|}{ Manistee } \\
\hline & \multicolumn{3}{|c|}{ Mason } \\
\hline & \multicolumn{3}{|c|}{ Mecosta_-2 } \\
\hline & \multicolumn{2}{|c|}{$\begin{array}{l}\text { Mecosta } \\
\text { Missaukee }\end{array}$} & 75 \\
\hline & \multicolumn{2}{|c|}{ Monroe_. } & 75 \\
\hline & \multicolumn{2}{|c|}{ Montcalm } & 75 \\
\hline & \multicolumn{2}{|c|}{ Muskegon } & --- \\
\hline & \multicolumn{2}{|c|}{ Newaygo } & 75 \\
\hline & \multicolumn{2}{|c|}{ Oceana_- } & 75 \\
\hline & \multicolumn{2}{|c|}{ Osceola } & 75 \\
\hline & \multicolumn{3}{|c|}{ Oscoda } \\
\hline & Ottawa & & \\
\hline & Saginaw & & 75 \\
\hline & St. Clair & & --- \\
\hline & Sanilac $_{-1-}$ & 73,74 & 75 \\
\hline & Shiawassee & 73,74 & 75 \\
\hline & Tuscola & & 72 \\
\hline & Washtenaw & 73,74 & 75 \\
\hline Minnesota... & Houston_-_._._. Freeburg & & 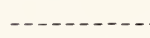 \\
\hline Mississippi _ - & Oktibbeha & & -...- - - \\
\hline Missouri_.. & Boone_..._._._. Columbia & 70,73 & -...- - - \\
\hline & Cape Girardeau _..._. Gordonville_-_. & & -...- - - \\
\hline & Grundy & 71 & -...- - - \\
\hline Nebraska_._._. & Dawson _.......... Gothenburg & $72,73,74$ & $---1-1-$ \\
\hline & 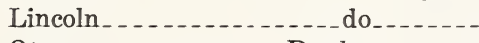 & & -------1 \\
\hline & Otoe & & -........ \\
\hline & Saline___._._._._. Milford _...... & & 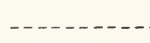 \\
\hline & Saunders_._._. & & $-\ldots-\ldots-$ \\
\hline New Hampshire... & Cheshire & $---1---1$ & -73 \\
\hline & Grafton & & $\ldots-\ldots$ \\
\hline & Hillsborough_._. & & 73 \\
\hline & Merrimack_... & & $---1--1$ \\
\hline & Strafford & & 68 \\
\hline New Jersey & Bergen_... & - - - - & 71 \\
\hline & Burlington & $\begin{array}{l}57,58,59 \\
\quad 60,65\end{array}$ & 61 \\
\hline & Camden, & .......... & 69 \\
\hline & Cumberland & - & 66 \\
\hline & Gloucester. & & 65 \\
\hline & Hunterdon & 60,65 & 61 \\
\hline
\end{tabular}


TABLE 1.-Species released and recovered in Eastern North America, ${ }^{1} 1957-75$-Con.

\begin{tabular}{|c|c|c|c|c|}
\hline $\begin{array}{c}\text { Species released } \\
\text { and State }\end{array}$ & County & Locality & $\begin{array}{l}\text { Year of } \\
\text { release } \\
(19-)\end{array}$ & $\begin{array}{c}\text { Year of } \\
\text { first } \\
\text { recovery } \\
(19-)\end{array}$ \\
\hline
\end{tabular}

Microctonus aethiopoides ${ }^{5}$

Continued

New Jersey-

Continued

New York

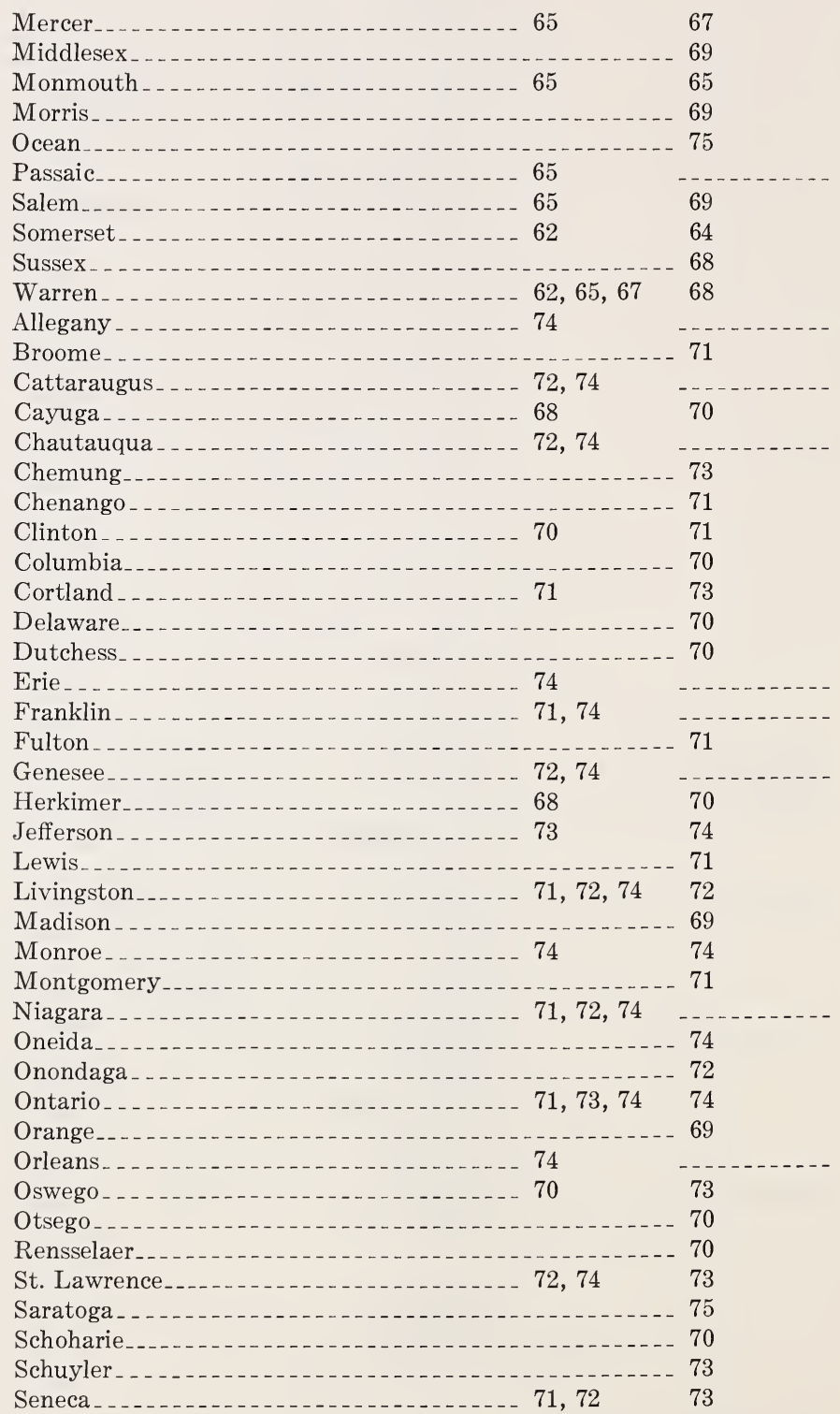


TABLE 1.--Species released and recovered in Eastern North America, ${ }^{1}{ }^{1957-75}$-Con.

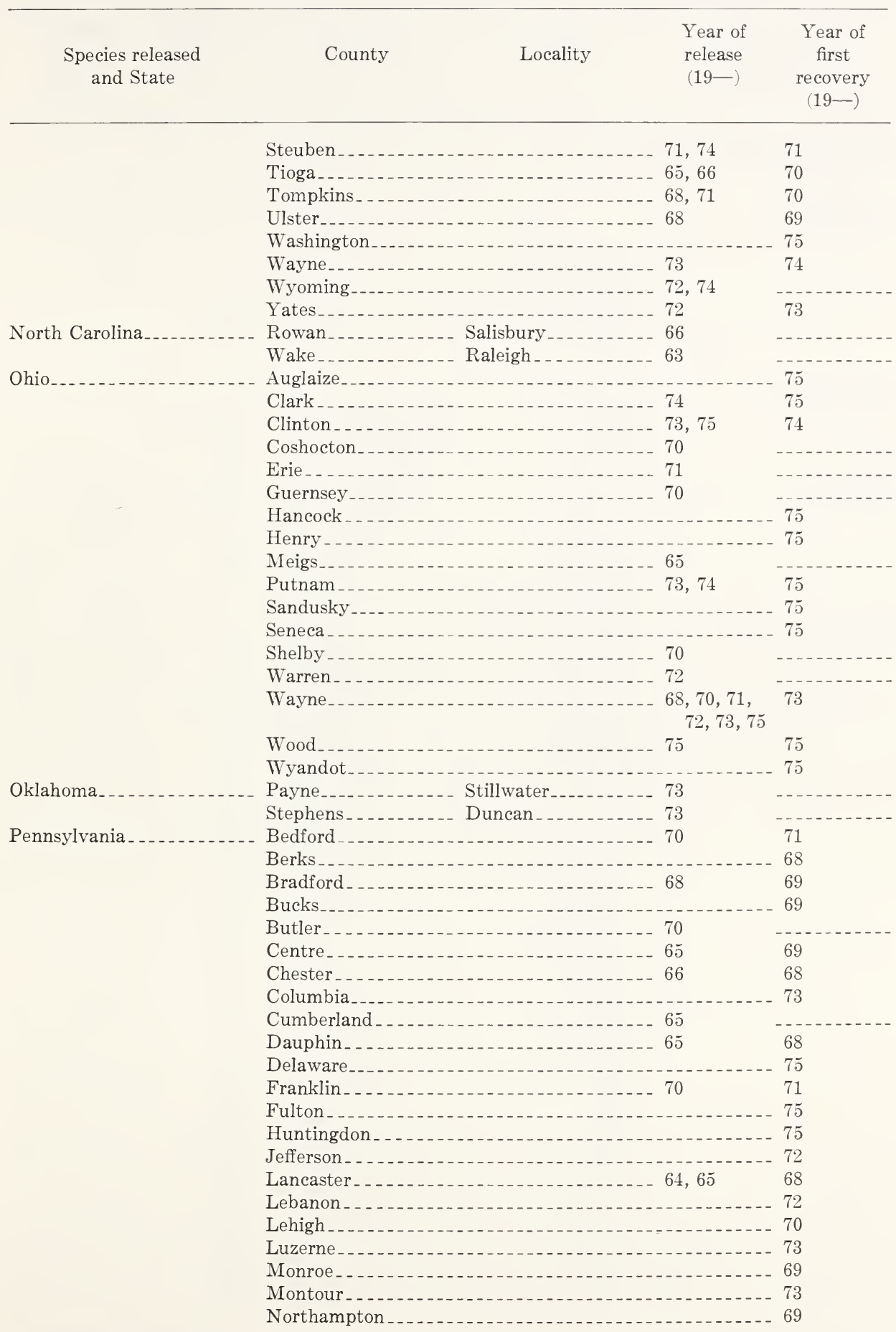

See footnotes at end of table. 
TABLE 1.-Species released and recovered in Eastern North America, ${ }^{1} 1957-75-$ Con.

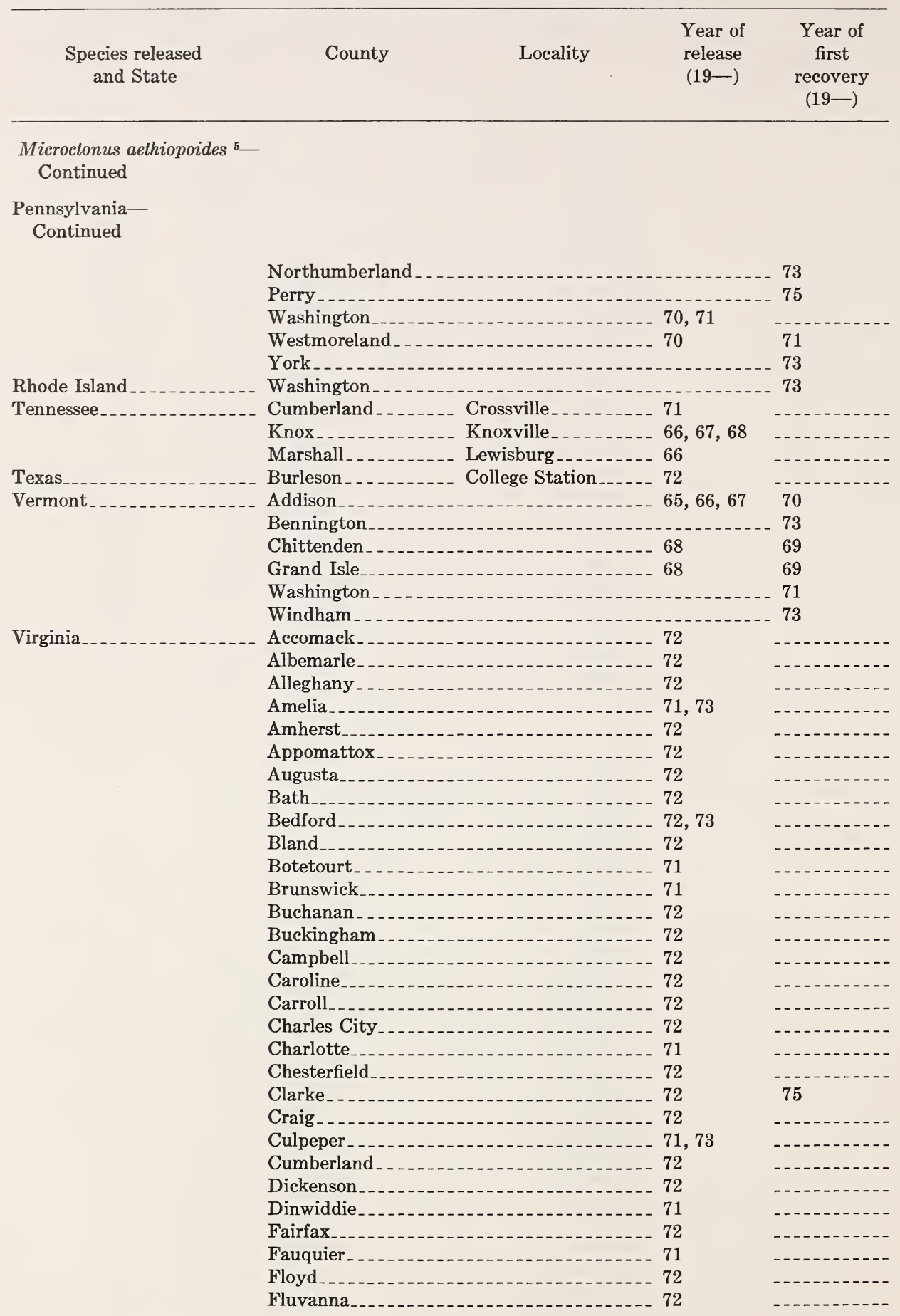


TABLE 1.-Species released and recovered in Eastern North America, ${ }^{1} 1957-75$-Con.

\begin{tabular}{|c|c|c|c|c|}
\hline $\begin{array}{c}\text { Species released } \\
\text { and State }\end{array}$ & County & Locality & $\begin{array}{l}\text { Year of } \\
\text { release } \\
(19-)\end{array}$ & $\begin{array}{l}\text { Year of } \\
\text { first } \\
\text { recovery } \\
(19-)\end{array}$ \\
\hline
\end{tabular}

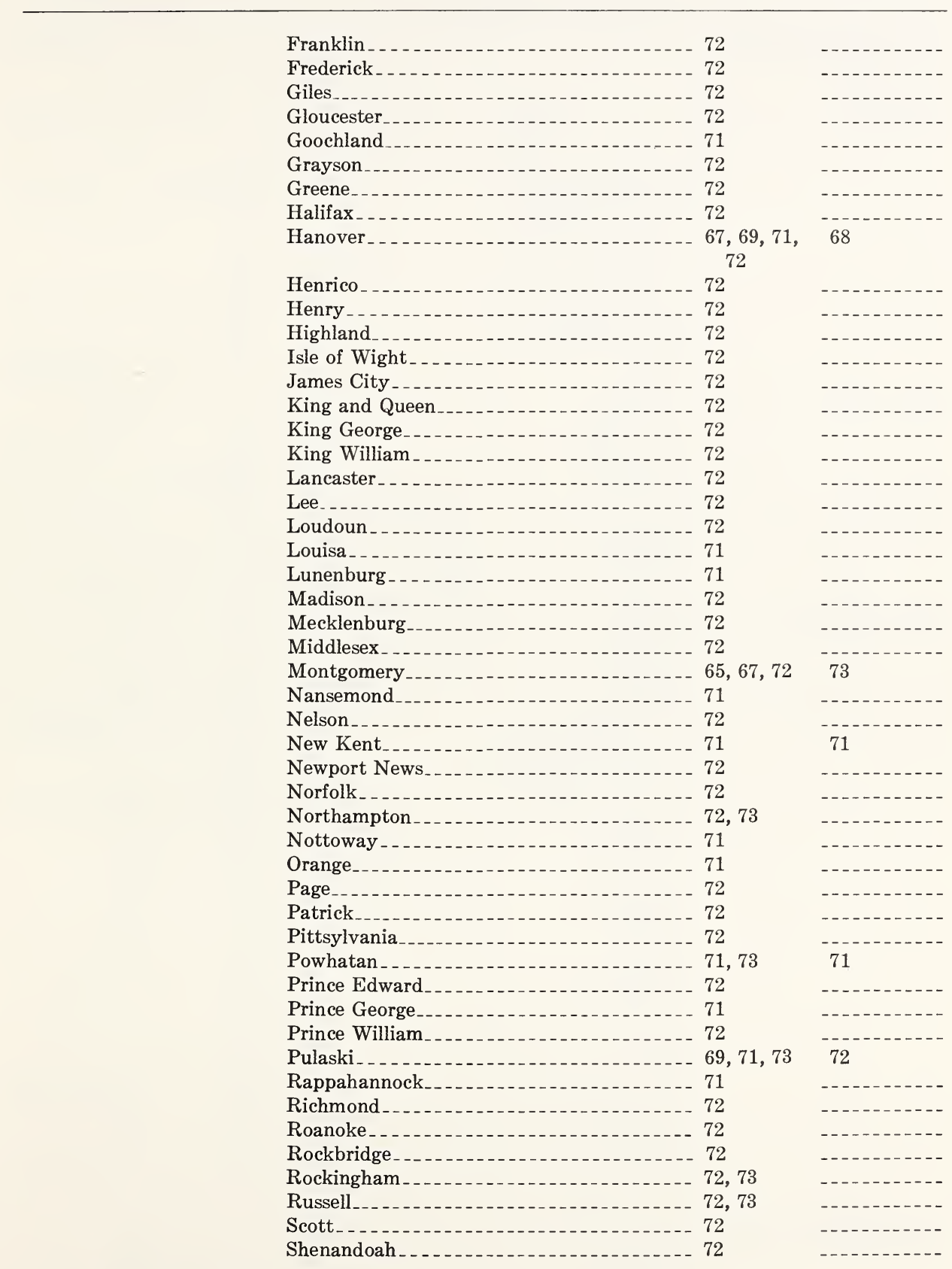


TABLE 1.-Species released and recovered in Eastern North America, ${ }^{1}$ 1957-75-Con.

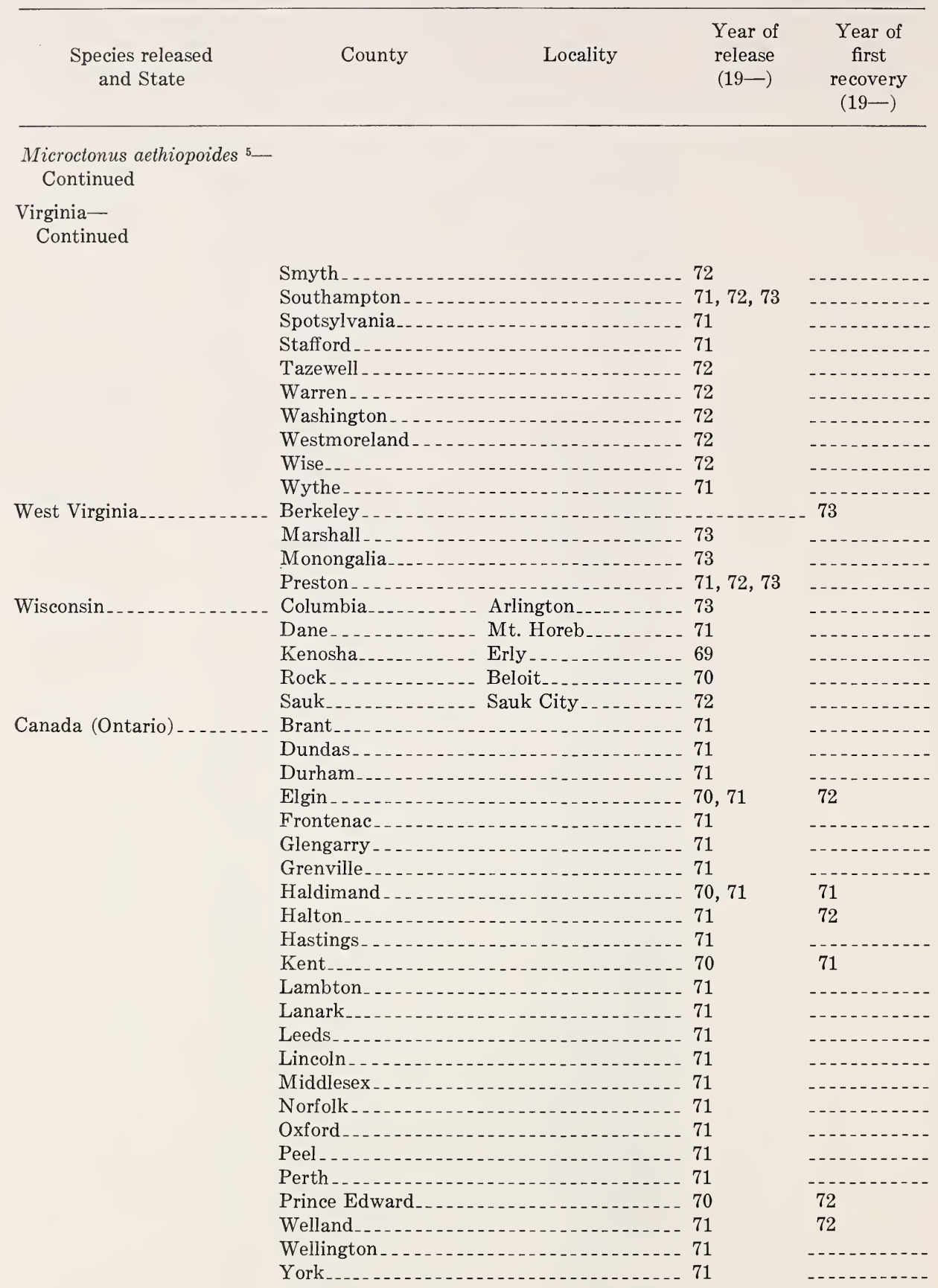

Microctonus colesi ${ }^{6}$

Connecticut
Tolland

Windham 
TABLE 1.-Species released and recovered in Eastern North America, ${ }^{1} 1957-75-C o n$.

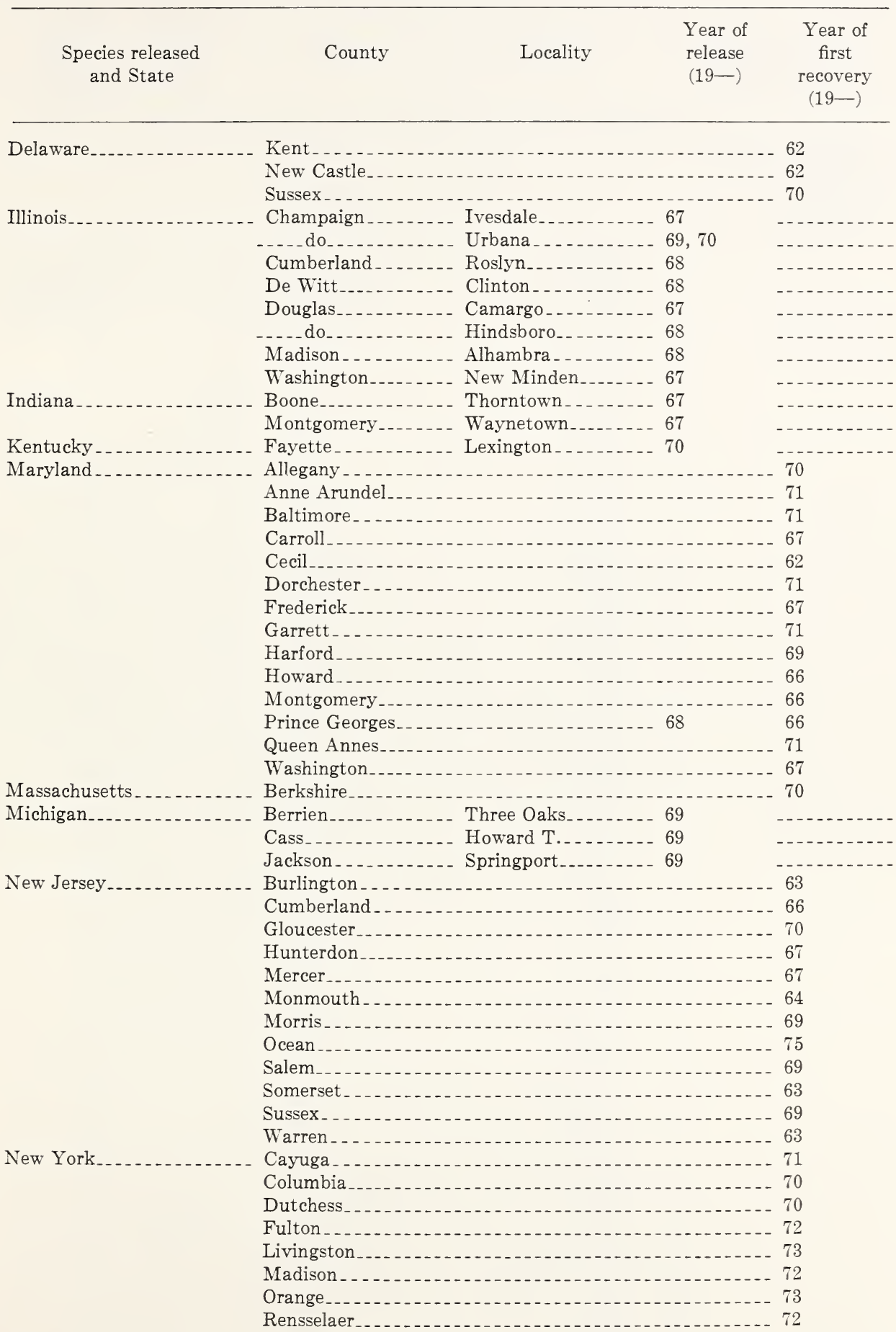


TABLE 1.-Species released and recovered in Eastern North America, ${ }^{1} 1957-75-C o n$.

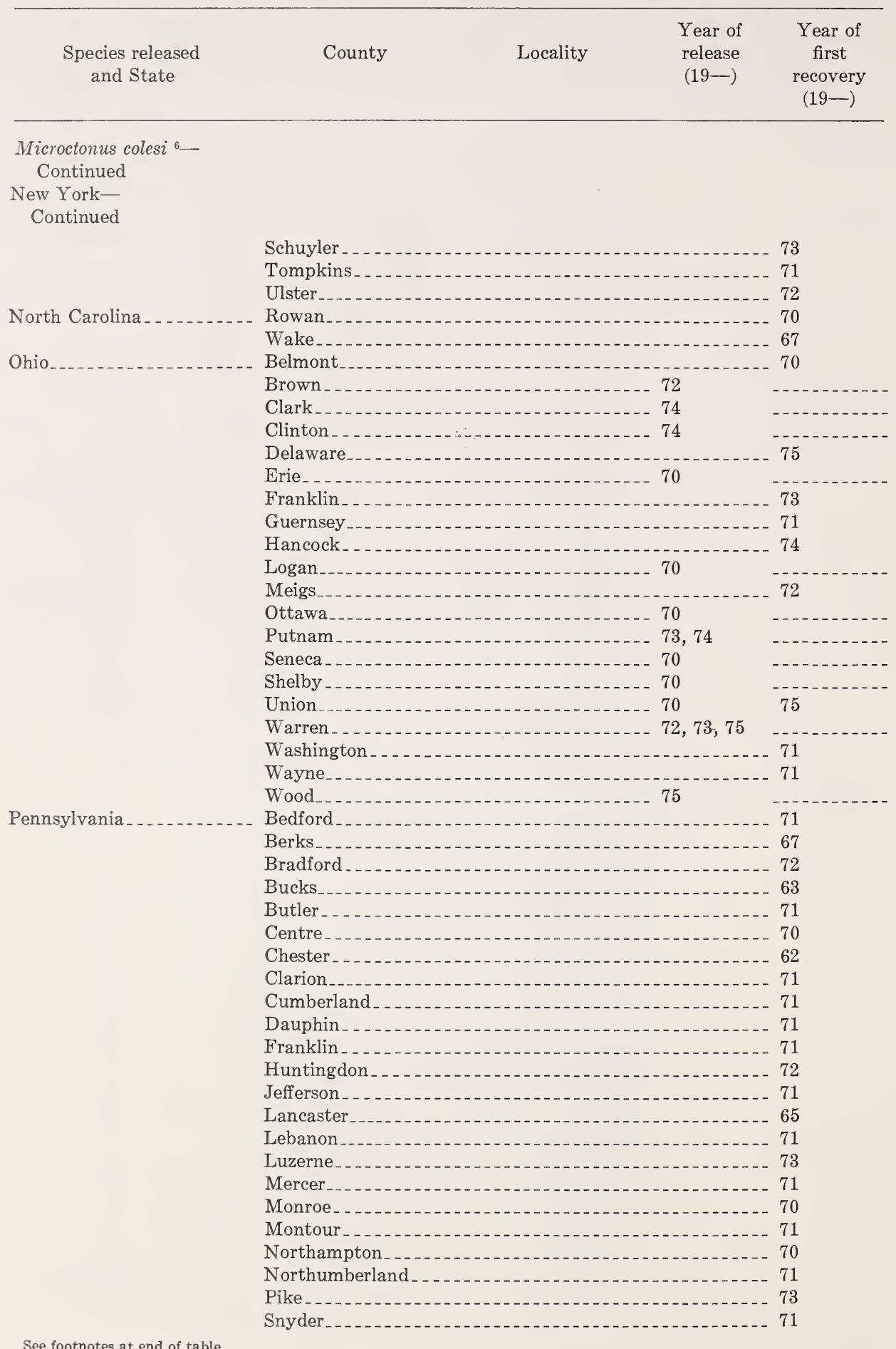


TABLE 1.-Species released and recovered in Eastern North America, ${ }^{1} 1957-75-C o n$.

\begin{tabular}{|c|c|c|c|c|}
\hline \multirow[t]{7}{*}{$\begin{array}{l}\text { Species released } \\
\text { and State }\end{array}$} & County & Locality & $\begin{array}{l}\text { Year of } \\
\text { release } \\
(19-)\end{array}$ & $\begin{array}{l}\text { Year of } \\
\text { first } \\
\text { recovery } \\
(19-)\end{array}$ \\
\hline & \multicolumn{4}{|c|}{ Somerset } \\
\hline & \multicolumn{4}{|c|}{ Union } \\
\hline & \multicolumn{4}{|c|}{ Washington } \\
\hline & \multicolumn{4}{|c|}{ Westmoreland } \\
\hline & \multicolumn{4}{|c|}{ York } \\
\hline & \multicolumn{4}{|c|}{ Washington } \\
\hline Vermont...... & \multicolumn{4}{|c|}{ Bennington } \\
\hline Virginia............. & \multicolumn{4}{|c|}{ Accomack } \\
\hline & \multicolumn{4}{|c|}{ Albemarle....... 72} \\
\hline & \multicolumn{4}{|c|}{ Alleghany } \\
\hline & \multicolumn{4}{|c|}{ Amelia } \\
\hline & \multicolumn{4}{|c|}{ Amherst } \\
\hline & \multicolumn{4}{|c|}{ Appomattox $\ldots \ldots \ldots$} \\
\hline & \multicolumn{4}{|c|}{$\begin{array}{l}\text { Appomattox } \\
\text { Augusta. }\end{array}$} \\
\hline & \multicolumn{4}{|c|}{ Bath } \\
\hline & \multicolumn{4}{|c|}{ Bedford } \\
\hline & \multicolumn{4}{|c|}{ Bland } \\
\hline & \multicolumn{4}{|c|}{ Buchanan } \\
\hline & \multicolumn{4}{|c|}{ Buckingham _........... 72} \\
\hline & Campbell_... _. & ........ & & - \\
\hline & Caroline ........ & $-1-1-1$ & & $-1-1-1-1$ \\
\hline & Carroll_........ & 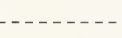 & & - \\
\hline & Charles City_- & ......... & & - - - - - - - \\
\hline & Charlotte & $-1-1-1-10$ & 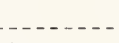 & 73 \\
\hline & Chesterfield _... & -........ & & 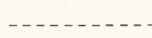 \\
\hline & Clarke ....... & $\ldots$ & & 70 \\
\hline & Craig . . . . . & $\ldots$ & & $\ldots-\ldots-n$ \\
\hline & Culpeper $\ldots . .$. & $\ldots$ & & $-\ldots-1-1-$ \\
\hline & Cumberland _. & $\ldots$ & & 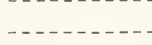 \\
\hline & Dickenson & $\ldots$ & & 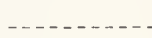 \\
\hline & Dinwiddie $\ldots . .$. & - n- & & 71 \\
\hline & Fairfax & $\ldots$ & & - \\
\hline & Floyd $\ldots \ldots$ & $\ldots$ & & $--\ldots-\ldots--$ \\
\hline & Fluvanna..... & $-\ldots$ & & $-\ldots-\ldots-\ldots$ \\
\hline & Franklin $\ldots$ & 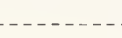 & & $-\ldots-\ldots \ldots-$ \\
\hline & Frederick & $-\ldots$ & & 70 \\
\hline & Giles.......... & 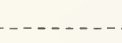 & & 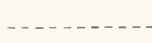 \\
\hline & Gloucester & $\ldots$ & & $--\ldots-\ldots$ \\
\hline & Grayson & - & & 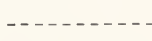 \\
\hline & 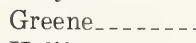 & $-\ldots-\ldots$ & & $-\ldots-\ldots-n$ \\
\hline & Halifax & . & & $-\ldots-\ldots-n$ \\
\hline & Hanover & $-\ldots$ & 71,72 & 71 \\
\hline & Henrico & $\ldots-\ldots$ & & $-\ldots-\ldots-1$ \\
\hline & Henry & $-\ldots$ & & $-\ldots-n-\ldots$ \\
\hline & Highland & - & & - \\
\hline & Isle of Wight & $-\ldots$ & & 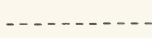 \\
\hline & James City & $---\ldots$ & & $\ldots$ \\
\hline & King and Quee & $\ldots-\ldots$ & & $-\ldots-\ldots-$ \\
\hline & King George... & 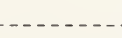 & & $-\ldots-\ldots-1$ \\
\hline & King William & - - - n & & 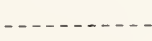 \\
\hline & Lancaster $\ldots$ & - & & $--\ldots-\ldots .$. \\
\hline & Lee $\ldots \ldots . . . .$. & $\ldots$ & 72 & $---n-1-n$ \\
\hline
\end{tabular}


TABLE 1.-Species released and recovered in Eastern North America, ${ }^{1} 1957-75-C o n$.

\begin{tabular}{|c|c|c|c|c|}
\hline $\begin{array}{c}\text { Species released } \\
\text { and State }\end{array}$ & County & Locality & $\begin{array}{l}\text { Year of } \\
\text { release } \\
(19-)\end{array}$ & $\begin{array}{l}\text { Year of } \\
\text { first } \\
\text { recovery } \\
(19-)\end{array}$ \\
\hline
\end{tabular}

Microctonus colesi ${ }^{6}$

Continued

Virginia-

Continued

\begin{tabular}{|c|c|c|}
\hline & Loudoun & \\
\hline & Madison & $-\ldots-1-1-1$ \\
\hline & Mecklenburg & 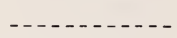 \\
\hline & Middlesex & $-\ldots-\ldots-1-1$ \\
\hline & Montgomery & 68 \\
\hline & Nelson & $--1-1-1-1$ \\
\hline & Newport News & $-\ldots \ldots$ \\
\hline & Norfolk & $-\ldots$ \\
\hline & Northampton & $---1-1-1$ \\
\hline & Nottoway & -70 \\
\hline & Page & $--1-1-1-$ \\
\hline & Patrick & - \\
\hline & Pittsylvania_. & $-1-1-1-1$ \\
\hline & Powhatan & 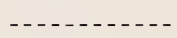 \\
\hline & Prince Edward & $-1-1-1-1$ \\
\hline & Prince William & $-1-1-1-1$ \\
\hline & Pulaski__. & $--1-1-1-1$ \\
\hline & Richmond & $-\ldots-1-1-1$ \\
\hline & Roanoke.... & $-\ldots-1-1-1$ \\
\hline & Rockbridge & 73 \\
\hline & Rockingham & 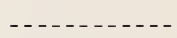 \\
\hline & Russell & $-1-1-1-1-1$ \\
\hline & Scott $_{\ldots}$ & $-1--1-1-$ \\
\hline & Shenandoah & $-\ldots-1 .-1$ \\
\hline & Smyth $\ldots \ldots \ldots$ & $-1-1-1-1$ \\
\hline & Southampton $\ldots \ldots$ & $-1-1-1-1$ \\
\hline & Tazewell $\ldots \ldots \ldots$ & $-\ldots-1-1$ \\
\hline & Warren & $-1-1-1-1$ \\
\hline & Washington & $-1-1-1-1$ \\
\hline & Westmoreland & $-\ldots$ \\
\hline & Wise-1. & $-1-1-1-1$ \\
\hline West Virginia.- & Berkeley & -73 \\
\hline & Greenbrier & -72 \\
\hline & Hardy & -72 \\
\hline & Jefferson & -70 \\
\hline & Mason & -72 \\
\hline & Monongalia. & -72 \\
\hline & Preston & -70 \\
\hline & Putnam & -72 \\
\hline Wisconsin ... & 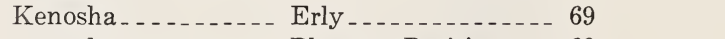 & $-1-1-1-1$ \\
\hline & _... do__. & $-1-1-1-1$ \\
\hline Canada (Ontario) & Prince Edward___-_- South Bay__-_-__-_- 70 & $-\ldots-1-1-1$ \\
\hline Patasson luna & & \\
\hline Delaware & Kent & 73 \\
\hline & New Castle & -60 \\
\hline Illinois_.. & Crawford & -67 \\
\hline & Hardin & -70 \\
\hline
\end{tabular}


TABLE 1.-Species released and recovered in Eastern North America, ${ }^{1}{ }^{1957-75-C o n .}$

\begin{tabular}{|c|c|c|c|c|}
\hline $\begin{array}{l}\text { Species released } \\
\text { and State }\end{array}$ & County & Locality & $\begin{array}{l}\text { Year of } \\
\text { release } \\
(19-)\end{array}$ & $\begin{array}{l}\text { Year of } \\
\text { first } \\
\text { recovery } \\
(19-)\end{array}$ \\
\hline
\end{tabular}

Indiana

Maryland .

Cecil

Howard

Prince Georges.

Massachusetts _......... Berkshire_._.

Hampshire

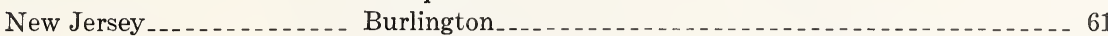

Warren

New York

Dutchess

Livingston

Tompkins

Ohio

Columbiana

Erie

Franklin

Lawrence

Mahoning -

Meigs

Wayne

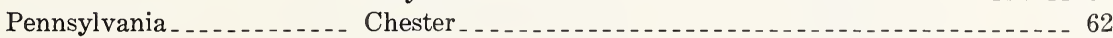

Fulton

Lancaster . . .

Philadelphia

Virginia

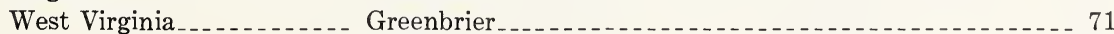

Hardy . . . . . . . 71

Mason

Preston

Canada (Ontario) _..... Carleton

Elgin

Essex

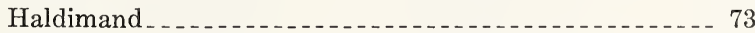

Halton - .

Kent

Lambton . . .

Lincoln _. . . . . . . . . 73

Middlesex _...

Oxford

Perth

Prince Edward . . .

Waterloo

Welland

Wellington $\ldots$

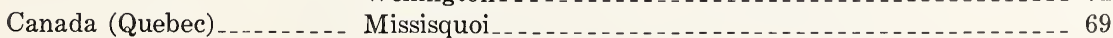

Tetrastichus incertus

Connecticut.

Delaware

Tolland

Kent

New Castle............ 62

Sussex . _ . _ .

See footnotes at end of table. 
TABLE 1.-Species released and recovered in Eastern North America, ${ }^{1}$ 1957-75-Con.

\begin{tabular}{|c|c|c|c|c|}
\hline $\begin{array}{l}\text { Species released } \\
\text { and State }\end{array}$ & County & Locality & $\begin{array}{l}\text { Year of } \\
\text { release } \\
(19-)\end{array}$ & $\begin{array}{l}\text { Year of } \\
\text { first } \\
\text { recovery } \\
(19-)\end{array}$ \\
\hline
\end{tabular}

Tetrastichus incertus-

Continued

Illinois

Bond . . . . . . . . . Donnellson _...... 66

Champaign _........ St. Joseph _........ 67

_..._do_._._._._.

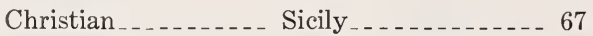

Coles.

De Witt_.......... Kenney ......... 68

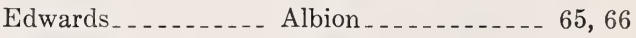

Effingham _....... Watson_......... 65

Fayette _......... Vandalia _._._._. 66

Fulton_........... Duncan Mills_._._._ 67

Gallatin _.......... Equality _......... 66

Hardin ........... Cave in Rock...... 64

Jackson _......... Carbondale....... 64

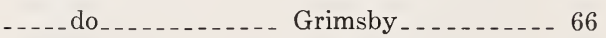

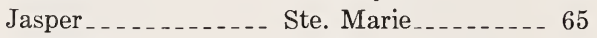

Jefferson_. _......... Texico__..._._._._. 65

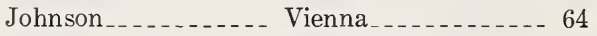

Logan_... _...... Mt. Pulaski _._._. 67

McLean_........ Le Roy_......... 67

Macon_........... Boody_........... 67

Madison_._._._. Alhambra _........ 66

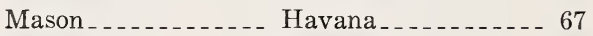

Massac____._._._. Mermet_..._._._._. 64

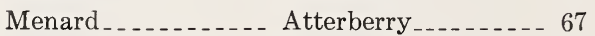

Piatt_._._._._._. Lodge_._._._._._. 67

Pike_..._._._._. . . New Hartford__._. . 67

Pope _._._._._._. Eddyville__._._._._. 64

Pulaski__._._._._. Mounds _._._._._. 64

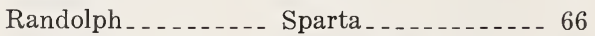

St. Clair_______ Fayetteville______ 66

Saline_._._._._._. Galatia

Sangamon . . . . . Mechanicsburg _._. 67

Scott_............. Winchester........ 67

Vermilion _. . . . _._. East Lynn_._._._._. 67

White_._._._._. Brownsville___._._. 66

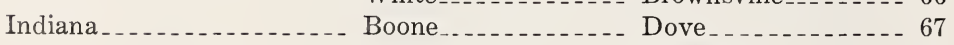

Boone

Harrison $\ldots . . .65,66$

Jackson _. . . . . . Brownstown _...... 66

Johnson_........... Samaria__._._._._. 66

La Porte........... Wanatah......... 68

Montgomery _..... Shannondale....... 67

_._._do_._._.

Ripley _.......... Ballstown_....... 66

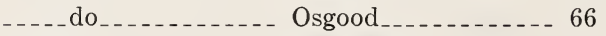

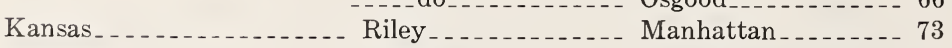

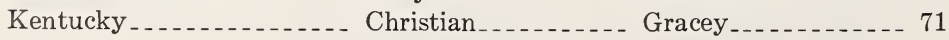

Fayette........... Lexington_........ 71

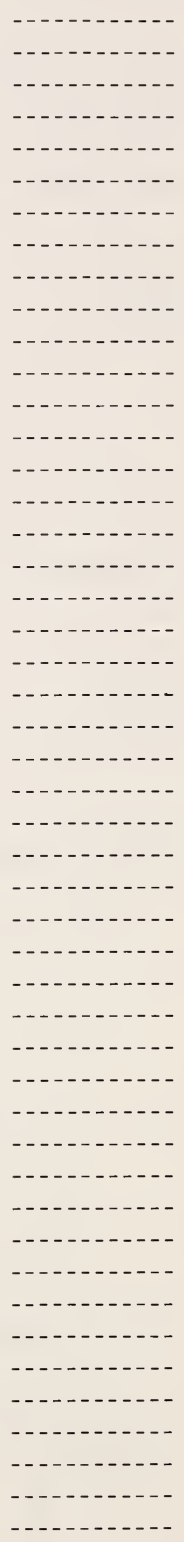


TABLE 1.-Species released and recovered in Eastern North America, ${ }^{1}{ }^{1957-75}$-Con.

\begin{tabular}{|c|c|c|c|}
\hline \multirow[t]{5}{*}{$\begin{array}{l}\text { Species released } \\
\text { and State }\end{array}$} & Locality & $\begin{array}{l}\text { Year of } \\
\text { release } \\
(19-)\end{array}$ & $\begin{array}{l}\text { Year of } \\
\text { first } \\
\text { recovery } \\
(19-)\end{array}$ \\
\hline & Lincoln $\ldots$ & 64 & \\
\hline & Montgomery & $\ldots$ & $-{ }^{4} 65$ \\
\hline & Pulaski & 64 & $-\ldots$ \\
\hline & Todd $\ldots \ldots$ & 64 & $-\ldots$ \\
\hline Maine _..... & Cumberland & 69 & 73 \\
\hline \multirow{14}{*}{ Maryland _.............. } & Allegany & - - n- & -74 \\
\hline & Anne Arundel & 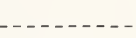 & -64 \\
\hline & Baltimore & $-\ldots$ & 64 \\
\hline & Carroll & $\ldots$ & 64 \\
\hline & Cecil__- & & 62 \\
\hline & Frederick. & $\ldots$ & 65 \\
\hline & Garrett & 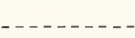 & -74 \\
\hline & Harford & 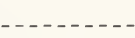 & 63 \\
\hline & Howard & $-\ldots-1 .-1$ & 64 \\
\hline & Kent & $-\ldots-n$ & -65 \\
\hline & Montgomery & 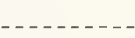 & -64 \\
\hline & Prince Georges & 65 & 65 \\
\hline & Queen Annes & $\ldots$ & -65 \\
\hline & Washington & $\ldots \ldots$ & -65 \\
\hline \multirow[t]{10}{*}{ Massachusetts _.......... } & Berkshire & 67 & 65 \\
\hline & Bristol & 64 & 66 \\
\hline & Essex & 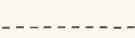 & - 66 \\
\hline & Franklin & 62 & 65 \\
\hline & Hampden & $\ldots \ldots$ & -65 \\
\hline & Hampshire & 62,67 & 65 \\
\hline & Middlesex & $-\ldots-\ldots-1$ & 67 \\
\hline & Norfolk & 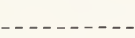 & 66 \\
\hline & Plymouth & $\ldots$ & 66 \\
\hline & Worcester & $\ldots$ & -65 \\
\hline \multirow{13}{*}{ Michigan } & Branch & 68 & --- \\
\hline & Calhoun & 68 & $-\ldots-\ldots$ \\
\hline & Cass $_{-}$ & 68,69 & $-\ldots-n$ \\
\hline & Eaton & 68 & 72 \\
\hline & Hillsdale & & $-\ldots$ \\
\hline & Ingham & 69 & 70 \\
\hline & Jackson & 68,69 & - \\
\hline & Kalamazoo_. & & 72 \\
\hline & Lenawee & & $-\ldots-n-1$ \\
\hline & Monroe & 68,69 & $-\ldots-1-1$ \\
\hline & St. Joseph & & 73 \\
\hline & Van Buren $\ldots$ & 68 & 73 \\
\hline & Washtenaw & 68 & $--1-1-$ \\
\hline \multirow[t]{9}{*}{ Missouri } & Cape Girardeau_.... Gordonville _. & 65 & $-\cdots-1-1$ \\
\hline & Carter _._. _._. & 65 & $\ldots \ldots$ \\
\hline & New Madrid_._._._. Sikeston & & $-\ldots \ldots$ \\
\hline & Pemiscot___._. _._. Steele & 65 & $-\ldots-n$ \\
\hline & Reynolds__._._._._. Garwood _.... & 65 & - n \\
\hline & - do & 64 & $\ldots \ldots$ \\
\hline & Stoddard & 64 & $-\ldots-\ldots$ \\
\hline & 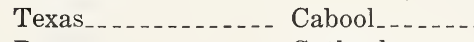 & 71 & 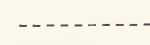 \\
\hline & Dawson _.......... Gothenburg & 73 & $-1-1-1$ \\
\hline
\end{tabular}


TABLE 1.-Species released and recovered in Eastern North America, ${ }^{1} 1957-75-C o n$.

\begin{tabular}{|c|c|c|c|c|}
\hline $\begin{array}{c}\text { Species released } \\
\text { and State }\end{array}$ & County & Locality & $\begin{array}{c}\text { Year of } \\
\text { release } \\
(19-)\end{array}$ & $\begin{array}{c}\text { Year of } \\
\text { first } \\
\text { recovery } \\
(19-)\end{array}$ \\
\hline
\end{tabular}

Tetrastichus incertusContinued

New Hampshire.

New Jersey

New York

See footnotes at end of table.

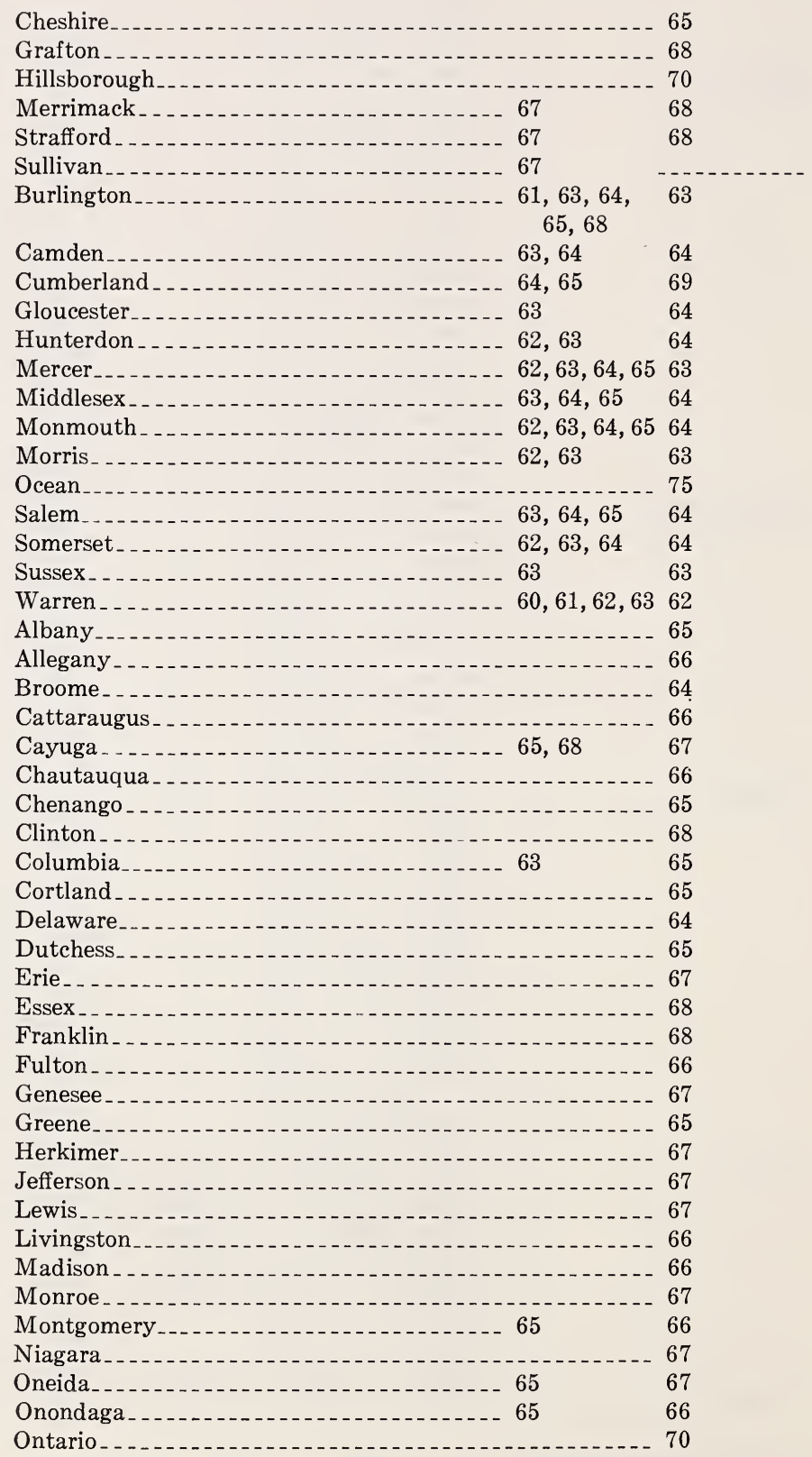

Grafton

Hillsborough _...

Sullivan

65,68

Camden

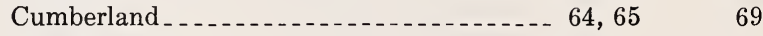

Gloucester.

Hunterdon . . . .

Mercer._._.

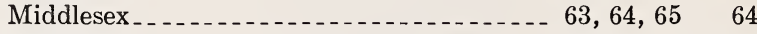

Monmouth . . . .

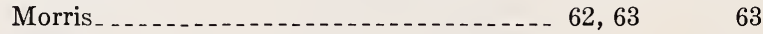

Ocean

Salem $\ldots \ldots \ldots 4,64,65 \quad 64$

Somerset_._.

Sussex _. _.

Warren $\ldots \ldots$ 6 $61,62,6362$

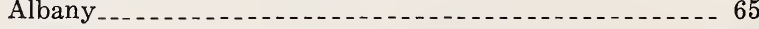

Allegany _.

Cayuga . . _ .

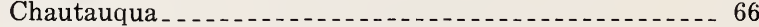

Chenango _.

Columbia

Cortland _.

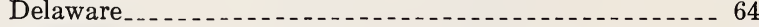

Dutchess..........

Erie _.

Essex

Franklin . . .

Fulton _...

Genesee

Herkimer._.

Jefferson _. - _

Lewis_...

Livingston

Madison _.

Monroe_.

Montgomery

Niagara_._.

Onondaga

Ontario . 
TABLE 1.-Species released and recovered in Eastern North America, ${ }^{1} 1957-75$-Con.

\begin{tabular}{|c|c|c|c|c|}
\hline $\begin{array}{c}\text { Species released } \\
\text { and State }\end{array}$ & County & Locality & $\begin{array}{l}\text { Year of } \\
\text { release } \\
(19-)\end{array}$ & $\begin{array}{l}\text { Year of } \\
\text { first } \\
\text { recovery } \\
(19-)\end{array}$ \\
\hline
\end{tabular}

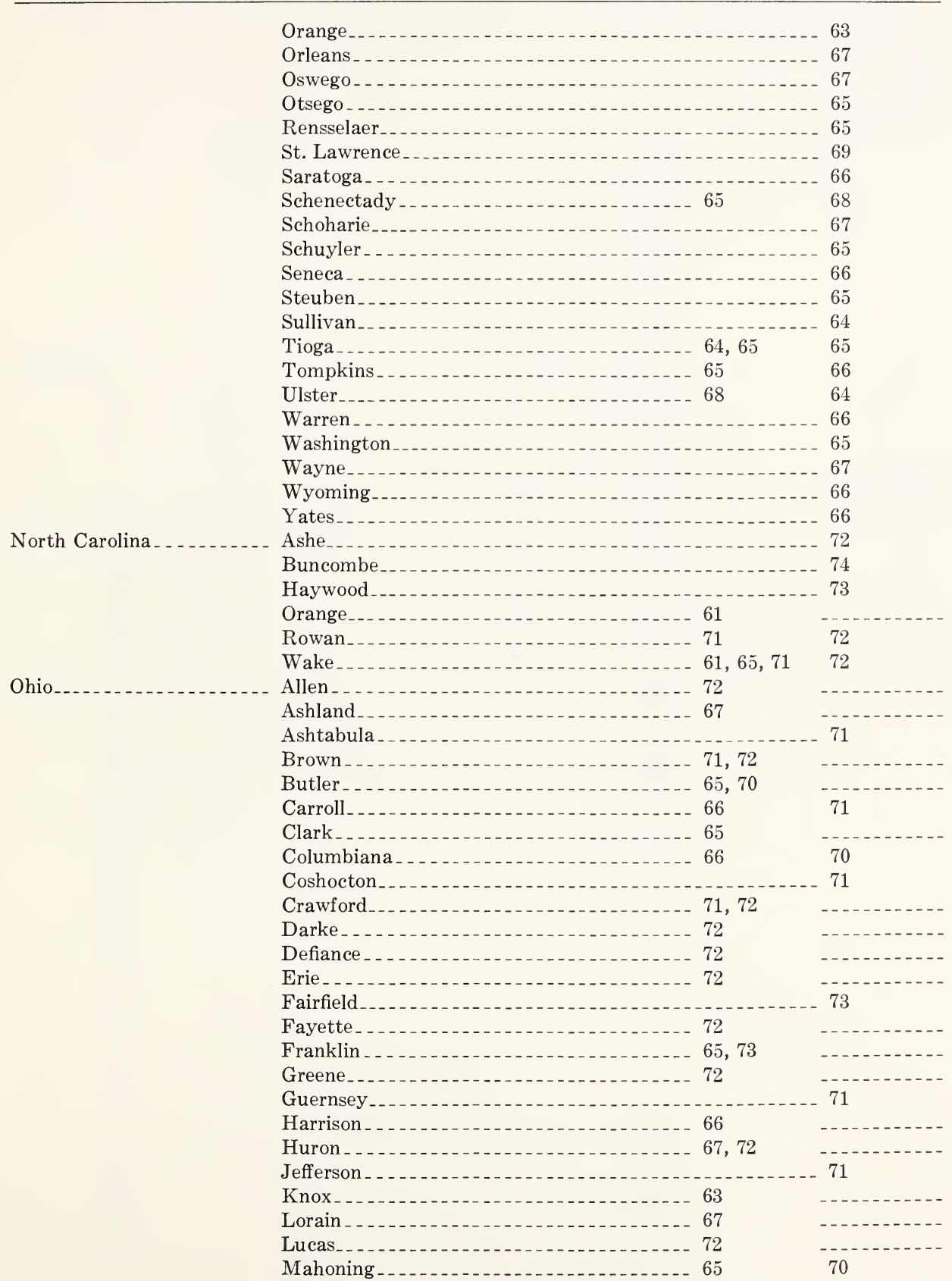


TABLE 1.-Species released and recovered in Eastern North America, ${ }^{1}$ 1957-75-Con.

\begin{tabular}{|c|c|c|c|c|}
\hline $\begin{array}{l}\text { Species released } \\
\text { and State }\end{array}$ & County & Locality & $\begin{array}{l}\text { Year of } \\
\text { release } \\
(19-)\end{array}$ & $\begin{array}{l}\text { Year of } \\
\text { first } \\
\text { recovery } \\
(19-)\end{array}$ \\
\hline
\end{tabular}

Tetrastichus incertus-
Continued
Ohio-
Continued

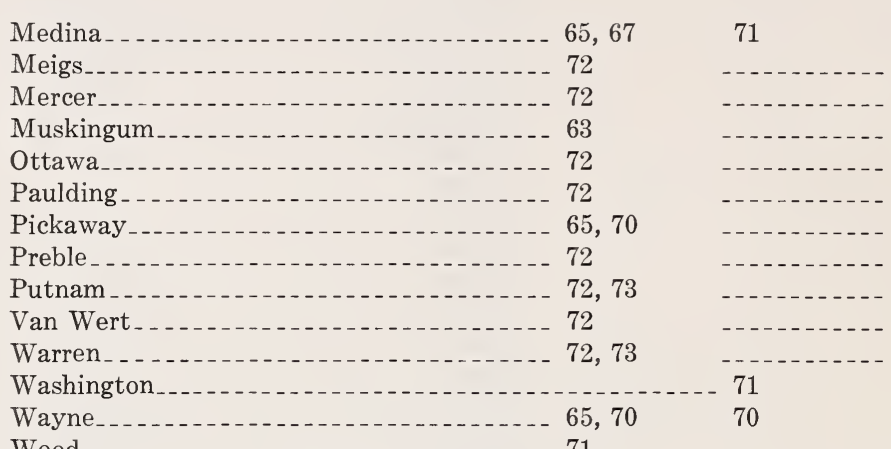

Oklahoma

Wood

Pennsylvania

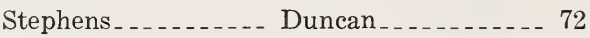

Adams_...

Bedford

Berks

Blair-a.t. 65

Bradford

Bucks

Butler.............. 70

Cambria

Centre

Chester.1.1. 62

Clarion_._.

Clearfield _...

Clinton - .

Crawford

Cumberland . _._._._. 70

Dauphin _. .

Delaware_............... 64

Erie

Franklin - .

Fulton

Huntingdon . . . . . . . . . . . . . . 64

Jefferson

Lancaster . . . . . 62

Lebanon

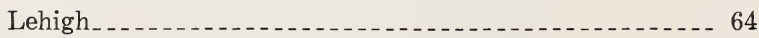

Lycoming . . . . . 65

Mercer_...

Mifflin........... 64

Monroe

Montgomery

Montour . . 69

Northampton

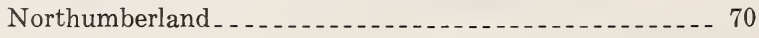


TABLE 1.-Species released and recovered in Eastern North America, ${ }^{1}{ }^{1957-75-C o n}$.

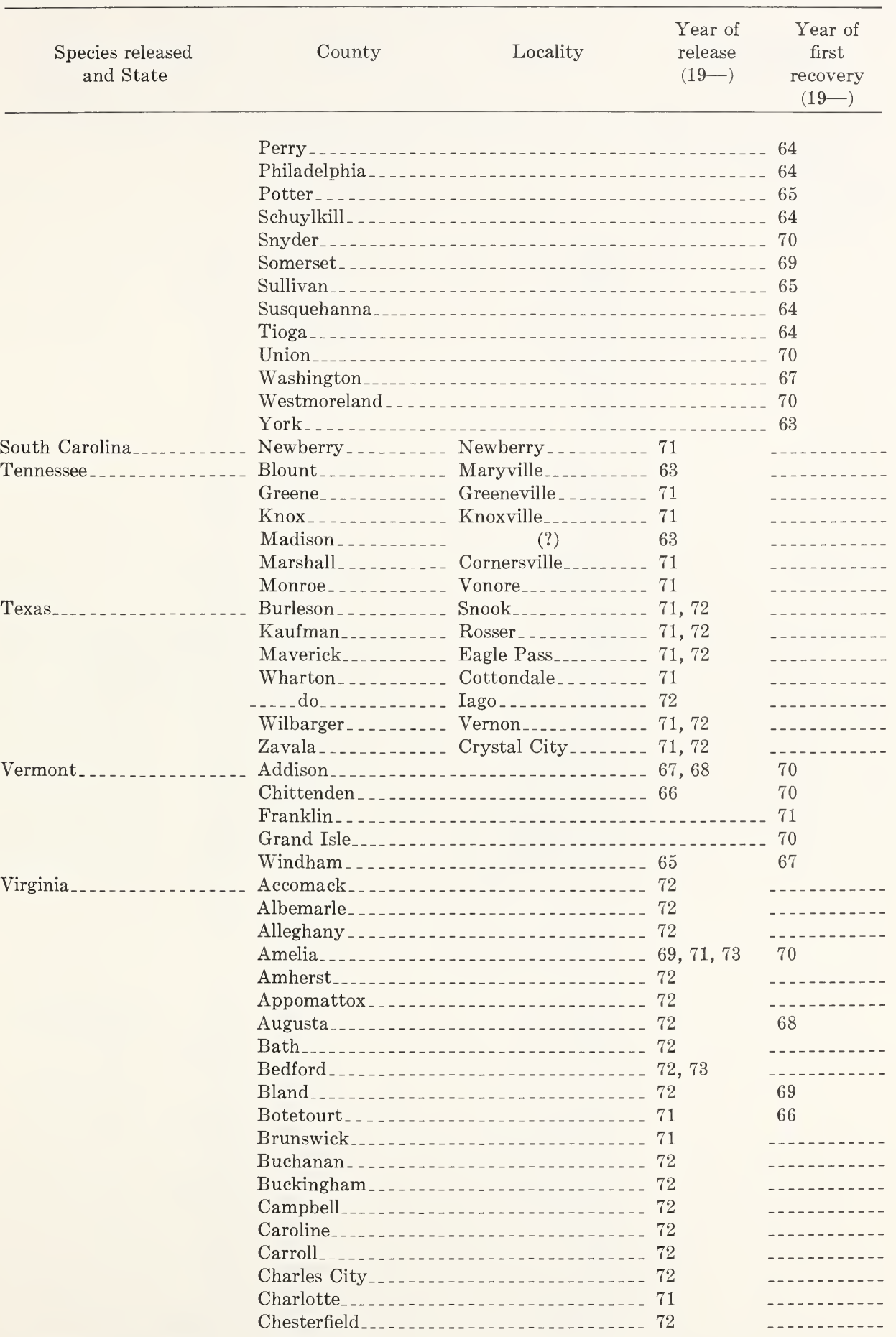


TABLE 1.-Species released and recovered in Eastern North America, ${ }^{1} 1957-75$-Con.

\begin{tabular}{|c|c|c|c|c|}
\hline $\begin{array}{c}\text { Species released } \\
\text { and State }\end{array}$ & County & Locality & $\begin{array}{l}\text { Year of } \\
\text { release } \\
(19-)\end{array}$ & $\begin{array}{l}\text { Year of } \\
\text { first } \\
\text { recovery } \\
(19-)\end{array}$ \\
\hline
\end{tabular}

Tetrastichus incertus-
Continued
Virginia--
Continued

\begin{tabular}{|c|c|}
\hline Clarke _. & \\
\hline Craig & -- \\
\hline Culpeper & $-\ldots-1-1-1$ \\
\hline Cumberland & $-1-1-1-1-1$ \\
\hline Dickenson & 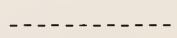 \\
\hline Dinwiddie & 71 \\
\hline Fairfax & $-1-1-1-$ \\
\hline Fauquier & $--1-1-1$ \\
\hline Floyd & $-1-1-1$ \\
\hline na. & 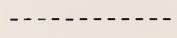 \\
\hline Franklin & $-\ldots$ \\
\hline rick__._. & --- \\
\hline Giles & 66 \\
\hline ester & --- \\
\hline Goochland & 71 \\
\hline Grayson & $-\ldots$ \\
\hline Greene & \\
\hline Halifax & 72 \\
\hline Hanover & 68 \\
\hline Henrico & 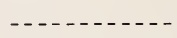 \\
\hline Henry $\ldots$ & --- \\
\hline Highland & 67 \\
\hline Isle of Wight & 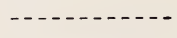 \\
\hline James City & 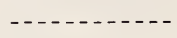 \\
\hline King and Queen & 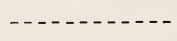 \\
\hline King George._. & 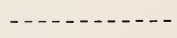 \\
\hline King William & $--1-1-$. \\
\hline Lancaster & $-1-1-1-1$ \\
\hline Lee & $-\ldots-1-10$. \\
\hline Loudoun & $-1-1-1-$. \\
\hline Louisa & $--1-1-$. \\
\hline Lunenburg & 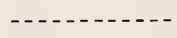 \\
\hline Madison & $-\ldots-1-1$. \\
\hline Mecklenburg & 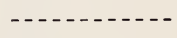 \\
\hline Middlesex & $-\ldots-1-10$ \\
\hline Montgomery & 66 \\
\hline Nansemond & $-\ldots . . .-1$ \\
\hline Nelson & 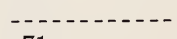 \\
\hline New Kent_... 69, 71 & 71 \\
\hline Newport News & $-1 .-1-1$ \\
\hline 72 & $-\ldots . .-1$ \\
\hline Northampton & $-1-1-1-1$ \\
\hline Nottoway & 71 \\
\hline Orange._. & 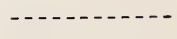 \\
\hline Page & $--1-\cdots-10$ \\
\hline Patrick & $-1-1-1-1$ \\
\hline Pittsylvania_. & $-1-\cdots+10$ \\
\hline Powhatan & 71 \\
\hline
\end{tabular}


TABLE 1.-Species released and recovered in Eastern North America, ${ }^{1} 1957-75$-Con.

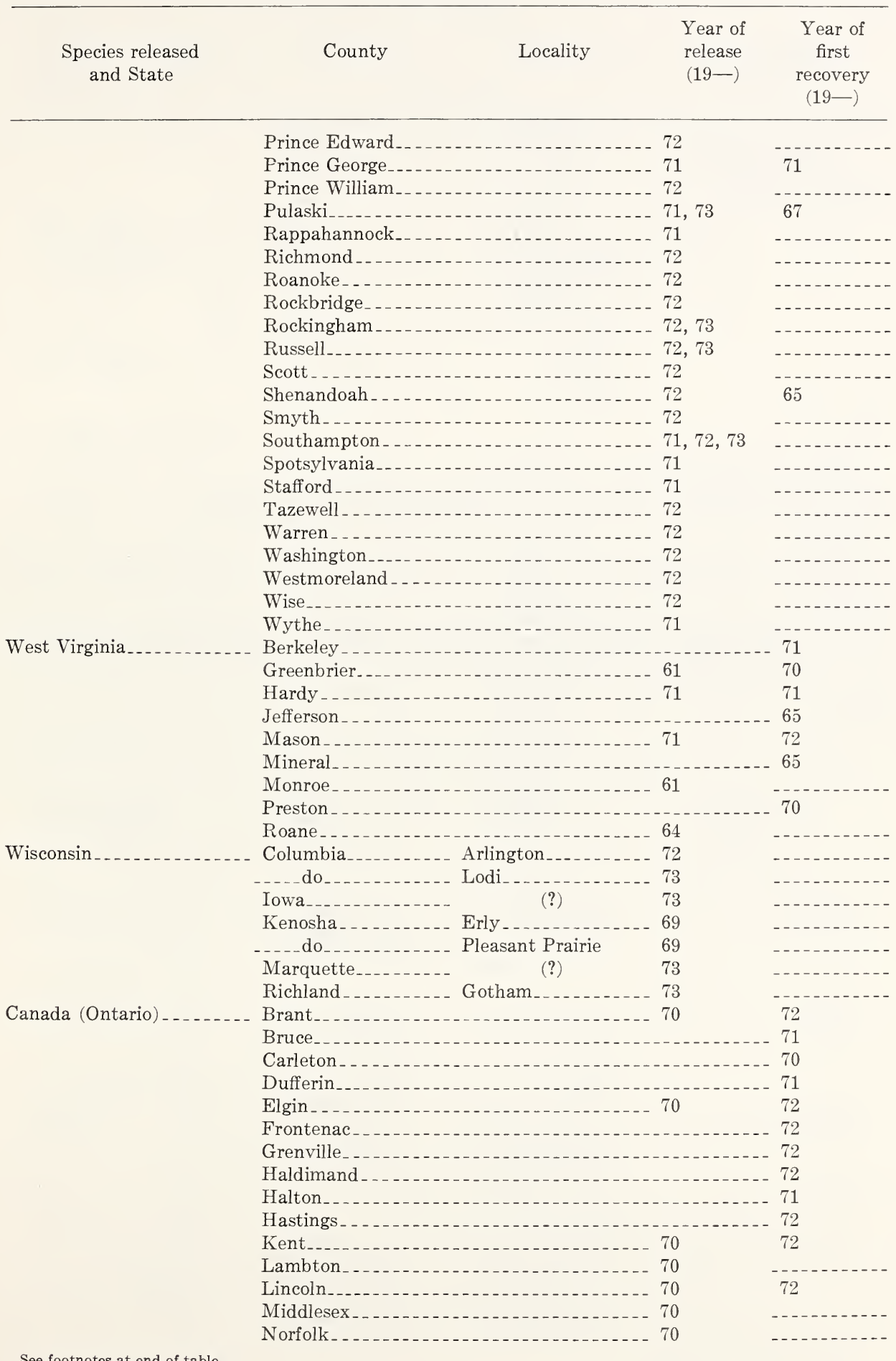


TABLE 1.-Species released and recovered in Eastern North America, ${ }^{1}{ }^{1957-75-C o n}$.

\begin{tabular}{|c|c|c|c|c|}
\hline $\begin{array}{l}\text { Species released } \\
\text { and State }\end{array}$ & County & Locality & $\begin{array}{l}\text { Year of } \\
\text { release } \\
(19-)\end{array}$ & $\begin{array}{l}\text { Year of } \\
\text { first } \\
\text { recovery } \\
(19-)\end{array}$ \\
\hline
\end{tabular}

Tetrastichus incertus-
$\quad$ Continued
Canada (Ontario) -
Continued

Northumberland _. .

Peel _._._.

Prince Edward

Waterloo

Welland

Wellington _.

Wentworth

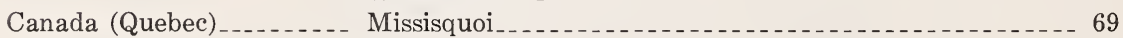

1 East of longitude $100^{\circ} \mathrm{W}$.

${ }^{2}$ Release and recovery counties for B. curculionis are shown on maps 4 and 5 . This species is now so widely distributed that it is unnecessary to tabulate release and recovery data.

${ }^{3}$ Because recoveries of $B$. stenostigma have been infrequent to date, place localities are shown for all releases.

${ }^{4}$ Permanent establishment at this locality is in doubt. Subsequent recovery attempts have been negative.

${ }^{5}$ List includes only releases against alfalfa weevil. During $1948-57$, several releases of $M$. aethiopoides were made against Sitona spp. in Manitoba, Minnesota, Nebraska, North Dakota, and Washington, but no recoveries are known.

${ }^{6} M$. colesi was not purposely introduced, but it is probably of foreign origin. See discussion on page 4.

TABLE 2.-Species released in Eastern North America ${ }^{1}$ but not recovered, 1957-75

\begin{tabular}{|c|c|c|c|}
\hline $\begin{array}{l}\text { Species released } \\
\text { and State }\end{array}$ & County & Locality & $\begin{array}{c}\text { Year of release } \\
(19-)\end{array}$ \\
\hline
\end{tabular}

Campogaster exigua ${ }^{2}$

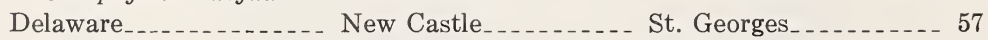

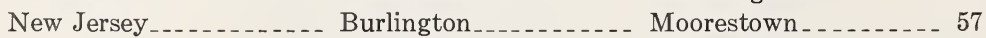

_..... do ............... Mount Holly _........ 57

Dibrachoides dynastes ${ }^{3}$

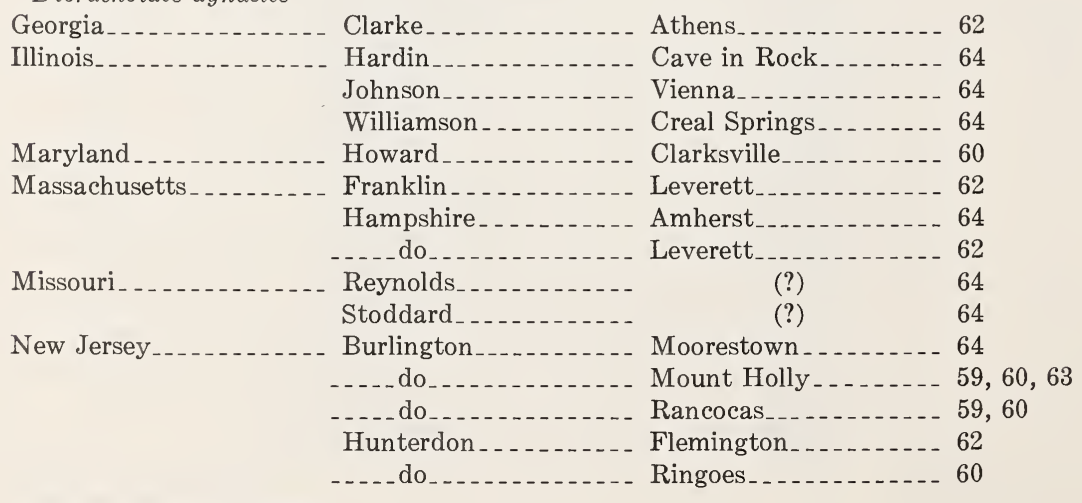

See footnotes at end of table. 
TABLE 2.-Species released in Eastern North America ${ }^{1}$ but not recovered, 1957-75 -Continued

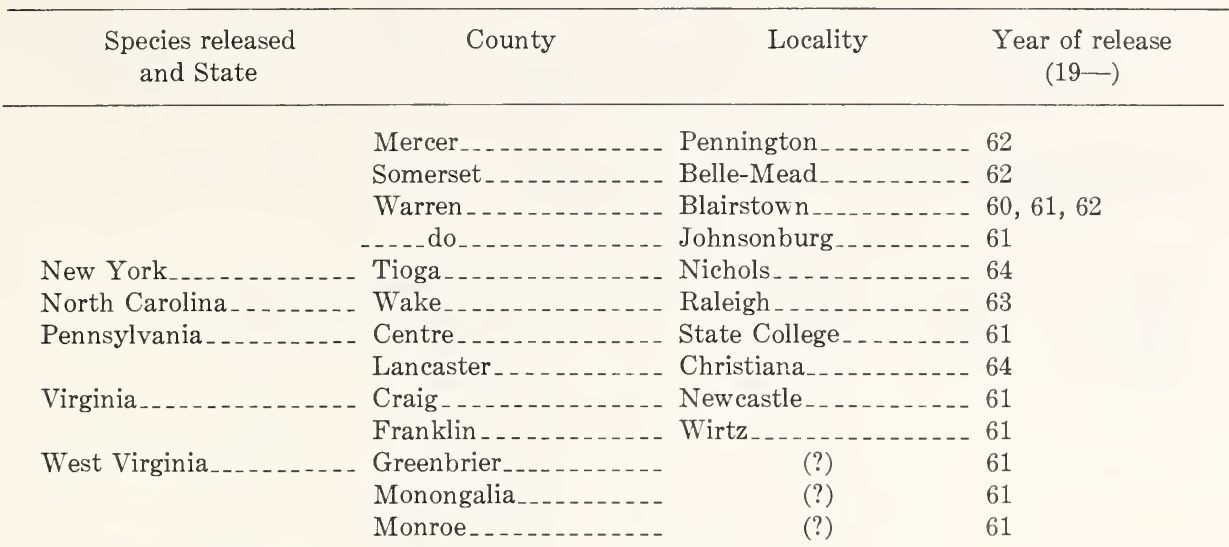

Microctonus stelleri

Delaware

New Castle_.._.

Sussex _._.

Illinois

Champaign _........ Urbana _. _........ 69

Douglas_............ Kemp_... _....... 68

Wayne_.......... Fairfield _._._._. 68

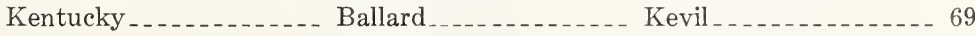

Fayette _._._._._. Lexington

Maryland _._._._._._. Frederick

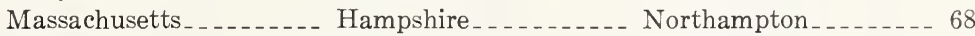

Michigan__._._._._._. Berrien_._._._._._. Three Oaks__._._._. 69

Cass_............. Howard T.......... 68

C._.

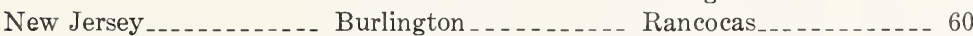

Salem

Sussex _._._._. Hamburg

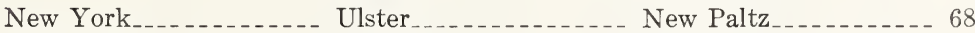

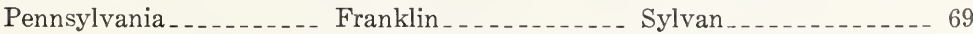

Northampton _....... Martins Creek _. _..._. 69

York

Vermont_._._._._._. Addison__._._._. Shoreham _..._._. 68

Virginia__._._._._._._. Augusta___._._._._. Steeles Tavern_....... 68

Charlotte

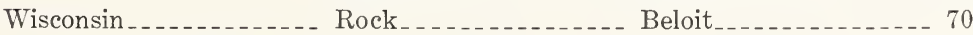

Necremnus leucarthros

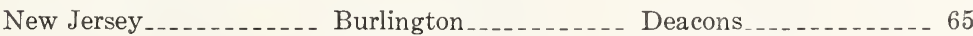

Mercer

Peridesmia discus

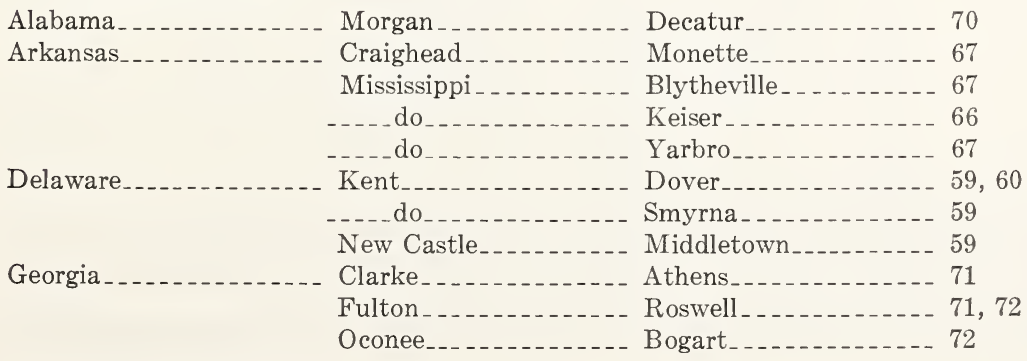

See footnotes at end of table. 
TABLE 2.-Species released in Eastern North America ${ }^{1}$ but not recovered, 1957-75 -Continued

\begin{tabular}{|c|c|c|c|}
\hline $\begin{array}{l}\text { Species released } \\
\text { and State }\end{array}$ & County & Locality & $\begin{array}{r}\text { Year of } \\
\quad(19\end{array}$ \\
\hline \multicolumn{4}{|l|}{$\begin{array}{l}\text { Peridesmia discus- } \\
\text { Continued }\end{array}$} \\
\hline \multicolumn{4}{|c|}{ Illinois_... } \\
\hline \multicolumn{4}{|c|}{ Kentucky _. . . . } \\
\hline \multicolumn{4}{|l|}{ Maryland ...... } \\
\hline \multirow[t]{2}{*}{ New Jersey } & - Burlington... & - Columbus _... & 59 \\
\hline & $\ldots$. $\mathrm{do}_{\ldots} \ldots$ & Medford . . . . & 59 \\
\hline & $\ldots \mathrm{do}_{-\ldots}$ & Mount Holly . . & 60 \\
\hline \multirow[t]{2}{*}{ North Carolina ... } & Rowan_... & Salisbury _..... & 66 \\
\hline & Wake $\ldots$ & $\begin{array}{l}\text { Raleigh } \\
\text { Wake Forest... }\end{array}$ & $\begin{array}{l}66,67 \\
67\end{array}$ \\
\hline Oklahoma_.... & Stephens & Duncan & 72 \\
\hline $\begin{array}{l}\text { Pennsylvania } \\
\text { South Carolina }\end{array}$ & Chester .... & Oxford $\ldots$ & 61 \\
\hline \multirow[t]{3}{*}{ South Carolina........ } & - Greenwood .... & - Ninety Six & 72 \\
\hline & Oconee......... & - Clemson_....... & 72 \\
\hline & Cumberland . . & - Crossville _. . - & 72 \\
\hline \multirow{5}{*}{ Tennessee _.. } & Knox & - Knoxville..... & 67 \\
\hline & Marshall _._. & Lewisburg - _. - & 66 \\
\hline & Maury ..... & Spring Hill _.. & 66 \\
\hline & Sullivan & Blountville _. _ & 72 \\
\hline & Burleson & Snook & 71,72 \\
\hline \multirow{8}{*}{ Texas_..- } & Kaufman_-- & Rosser . . . . . . & 72 \\
\hline & Maverick & Eagle Pass_.... & 72 \\
\hline & ..... do $\ldots \ldots . .$. & Quemado_.... & 71 \\
\hline & Wharton $\ldots . .$. & _ Boling _........ & 71 \\
\hline & $\ldots \mathrm{do}_{\ldots} \ldots \ldots$ & Iago $\ldots \ldots \ldots$ & 72 \\
\hline & Wilbarger ..... & Vernon & 72 \\
\hline & Zavala ......... & Crystal City ... & 71,72 \\
\hline & Accomack & Onancock & 59 \\
\hline \multirow{3}{*}{ Virginia_.. } & Charlotte...... & Red Oak . . . & 72 \\
\hline & Montgomery -.- & Blacksburg . ... & -72 \\
\hline & Rockbridge_... & - Steeles Tavern & -72 \\
\hline
\end{tabular}

Trichomalus inops

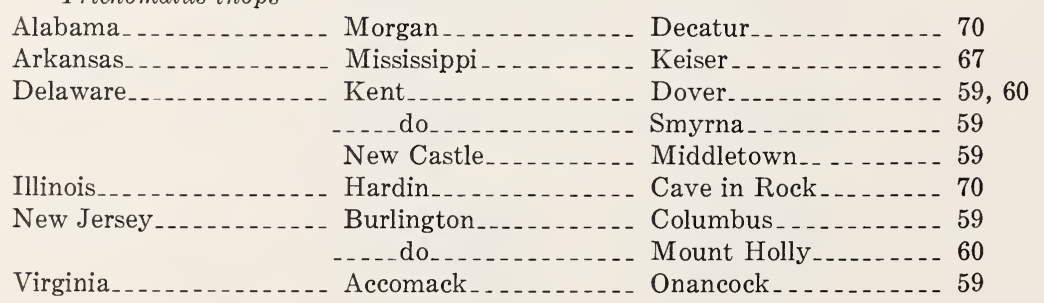

${ }^{1}$ East of longitude $100^{\circ} \mathrm{W}$.

${ }^{2}$ List includes only releases against alfalfa weevil. During 1948-57, several releases of C. exigua were made against Sitona spp. in Manitoba, Minnesota, Nebraska, North Dakota, and Washington, but no recoveries are known.

${ }^{3}$ Although $D$. dynastes has never been recovered in the East, it is known to be established in California. 


\section{APPENDIX}

TABLE 3.-Partial list of species released in the Western States ${ }^{1}$ and their origin, $1957-75$

[Includes only parasite material supplied through USDA sources]

\begin{tabular}{ccc}
\hline Species released, & Year of \\
State, and county & Locality & $\begin{array}{c}\text { release } \\
(19-)\end{array}$
\end{tabular}

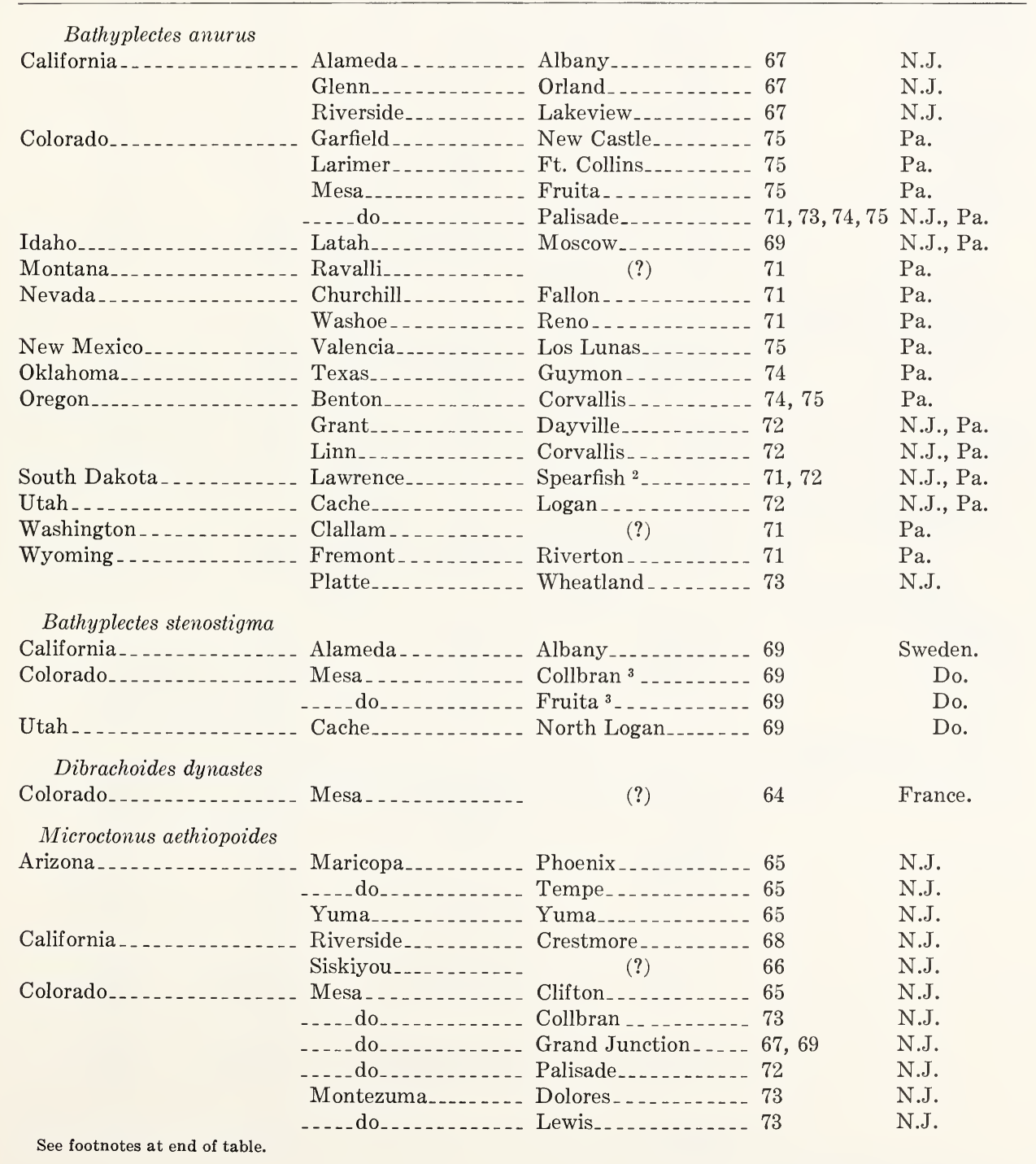


TABLE 3.-Partial list of species released in the Western States ${ }^{1}$ and their origin, 1957-75-Continued

\begin{tabular}{|c|c|c|c|}
\hline $\begin{array}{l}\text { Species released, } \\
\text { State, and county }\end{array}$ & Locality & $\begin{array}{l}\text { Year of } \\
\text { release } \\
(19-)\end{array}$ & Origin \\
\hline
\end{tabular}

\section{Microctonus aethiopoides- \\ Continued}

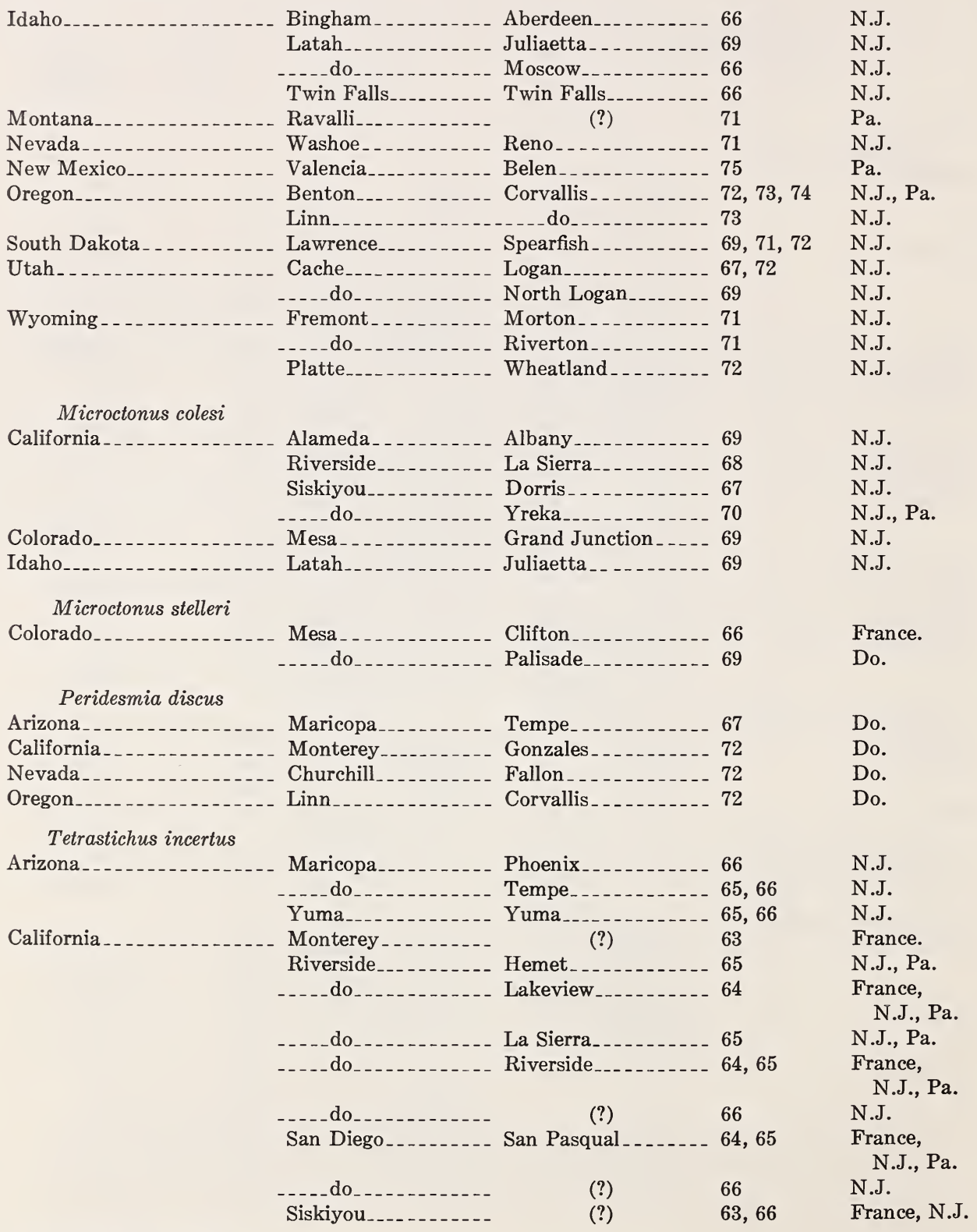


TABLE 3.-Partial list of species released in the Western States ${ }^{1}$ and their origin, 1957-75-Continued

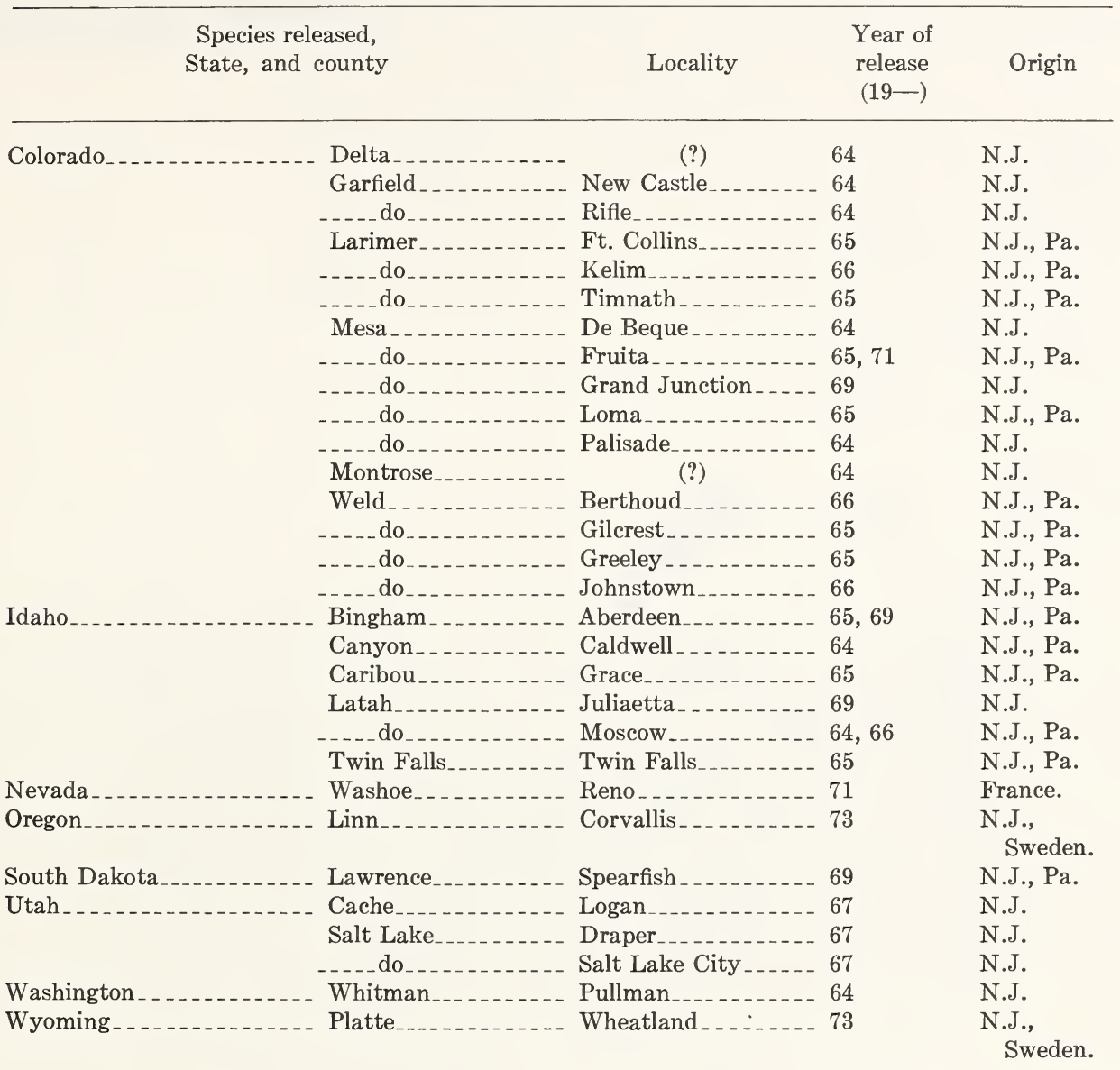

${ }^{1}$ West of longitude $100^{\circ} \mathrm{W}$.

${ }^{2}$ Recovered during 1973.

${ }^{3}$ Recovered during 1971 and 1975.

Note.-Many other parasite colonies have been liberated in the West. Since California has had an active parasite introduction program against Hypera postica and $H$. brunneipennis for many years, the California reports and publications should be consulted for a complete record. 



\section{PATASSON LUNA RECOVERIES (TABLE 1)}

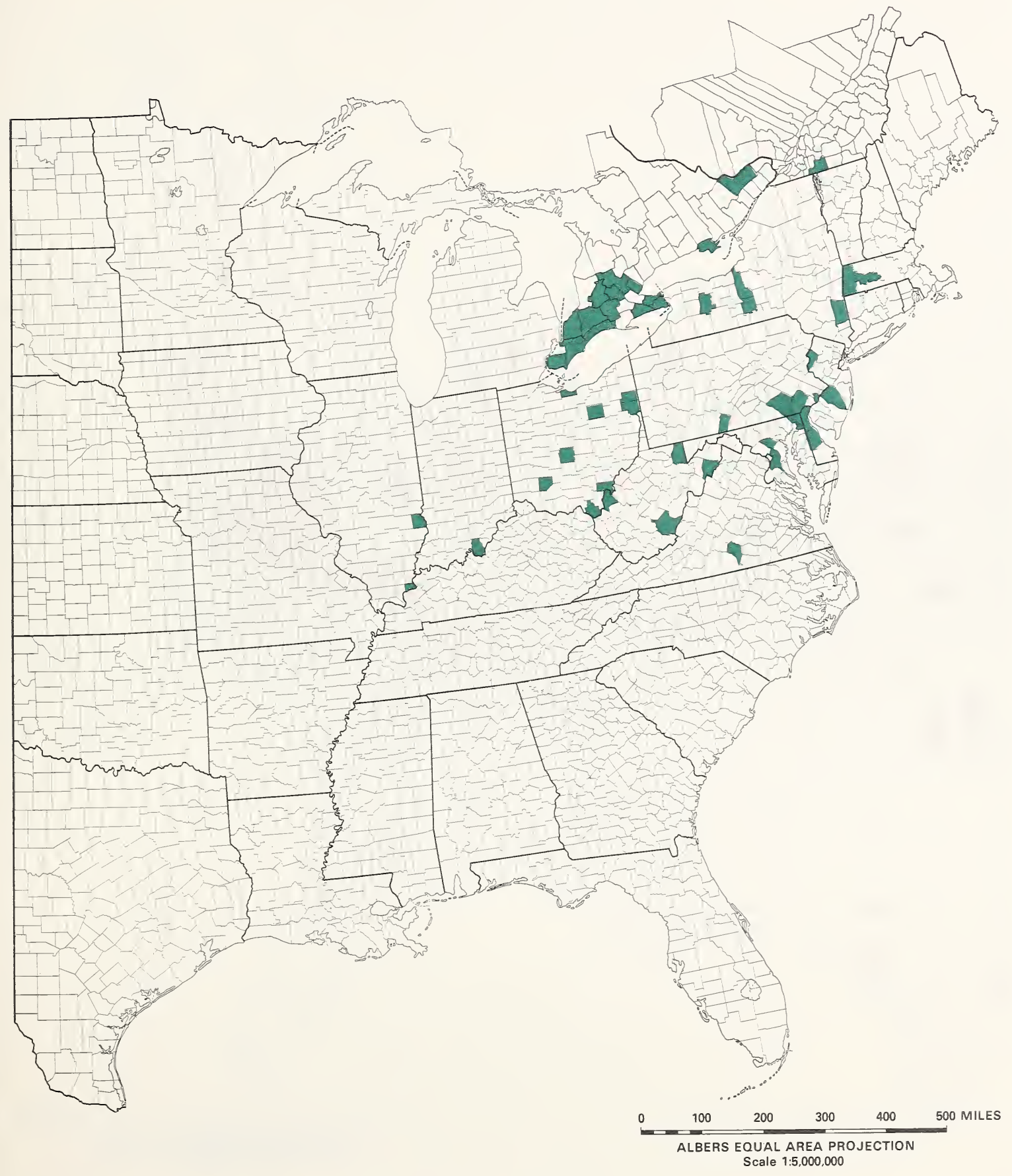




\section{BATHYPLECTES ANURUS RELEASES (TABLE 1)}

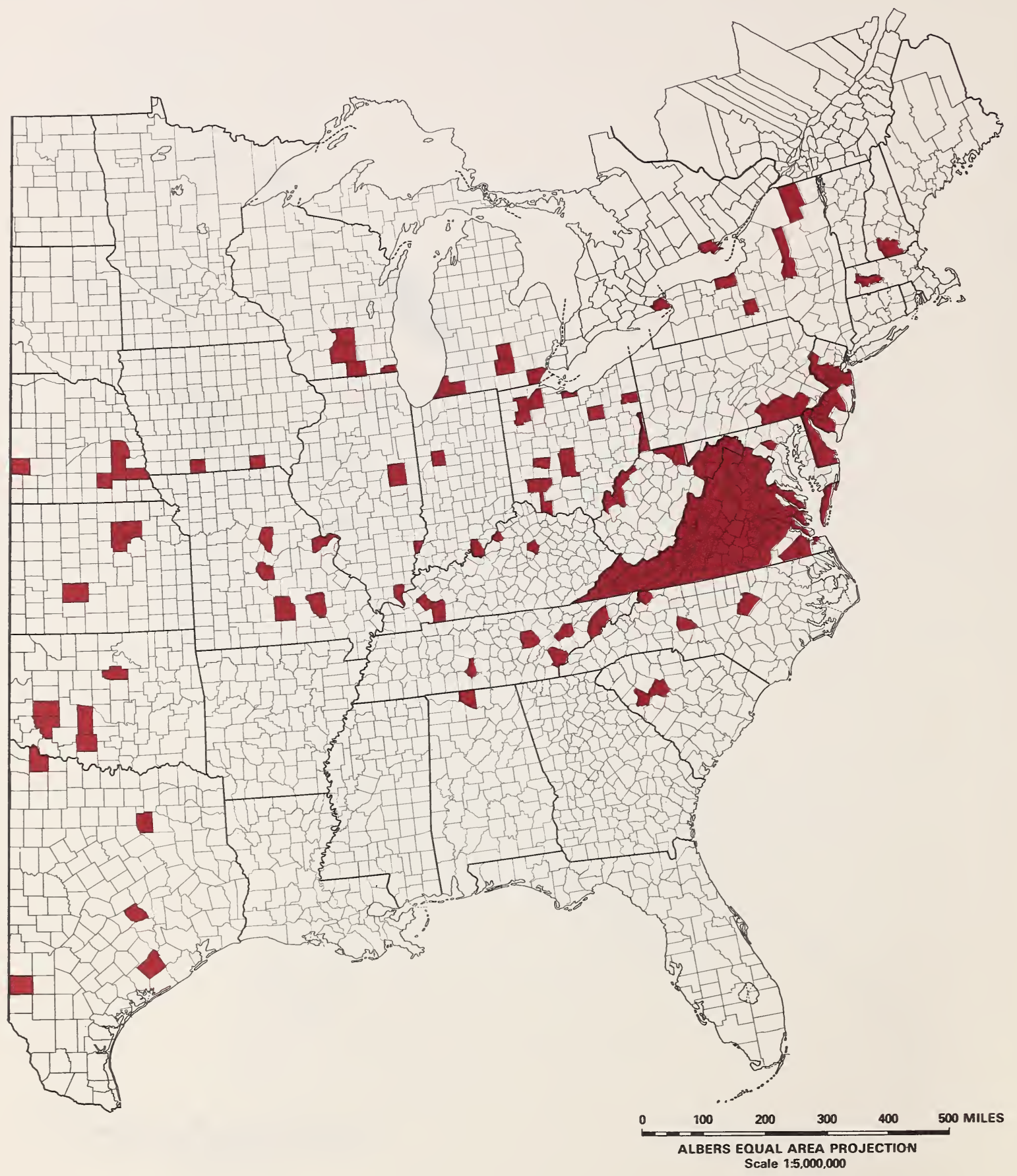


RELEASE AND RECOVERY OF INTRODUCED PARASITES OF THE ALFALFA WEEVIL 45

\section{BATHYPLECTES ANURUS RECOVERIES (TABLE 1)}

MAP 3

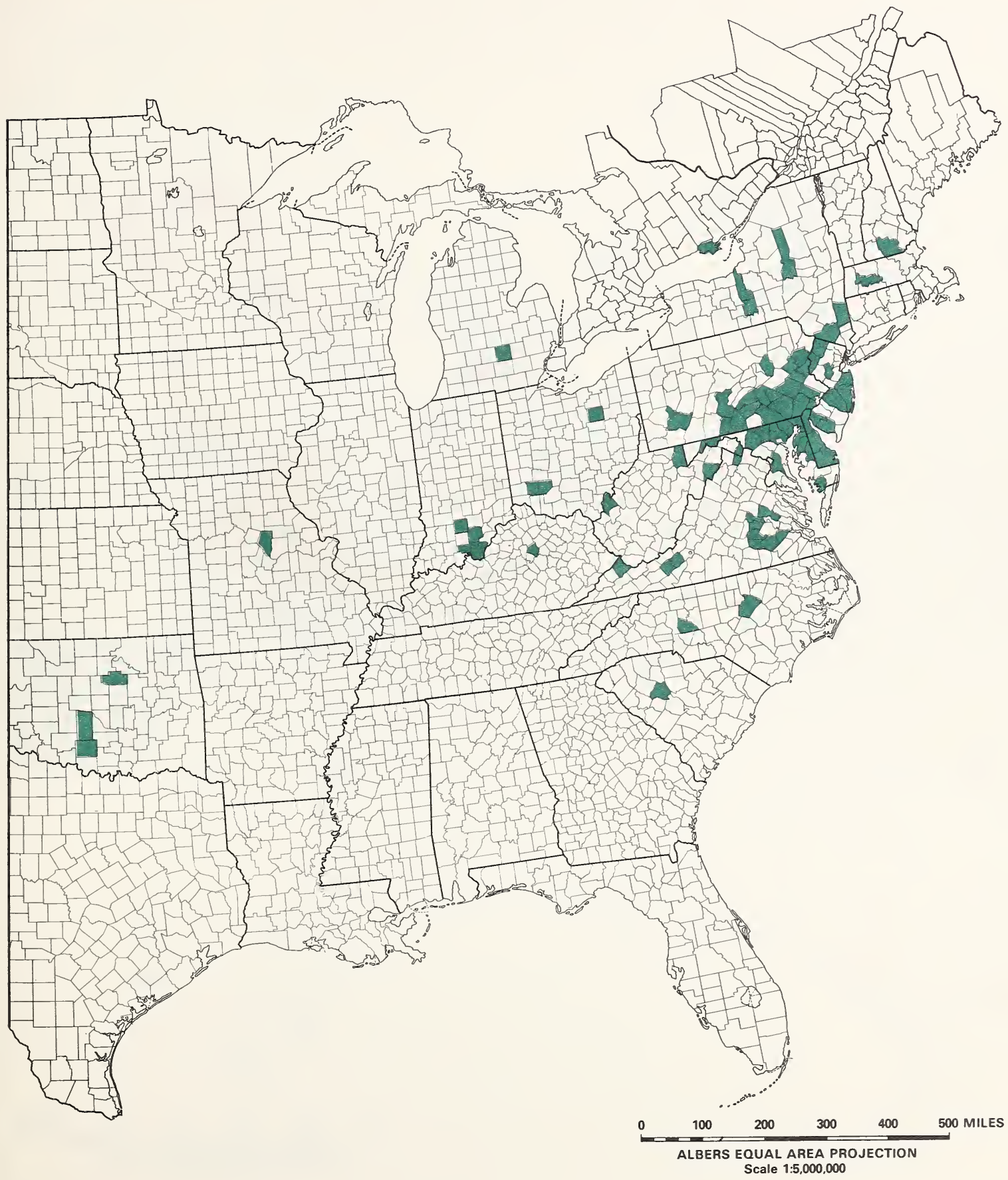




\section{BATHYPLECTES CURCULIONIS RELEASES}

MAP 4

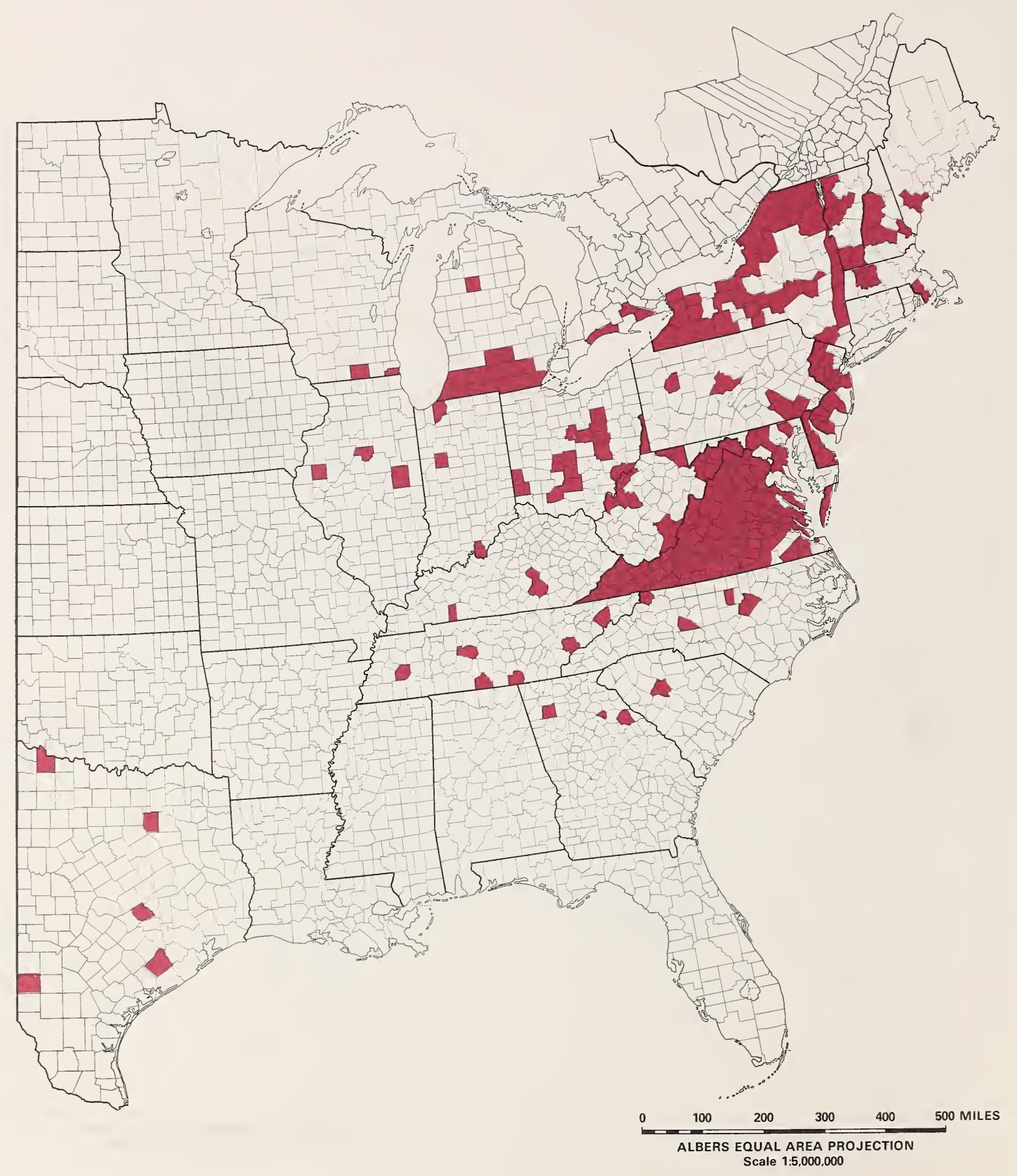




\section{BATHYPLECTES CURCULIONIS RECOVERIES}

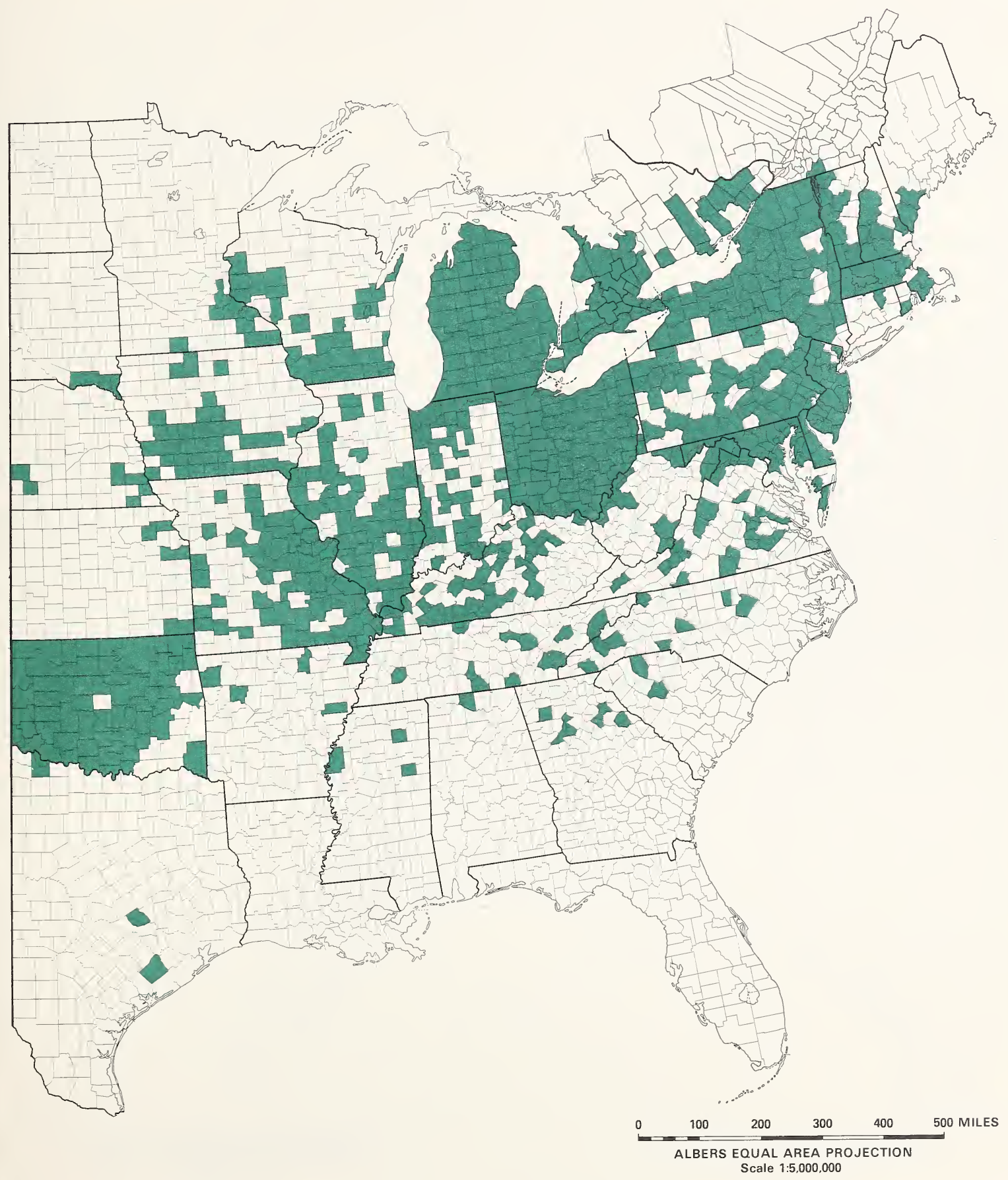




\section{BATHYPLECTES STENOSTIGMA RELEASES (TABLE 1)}

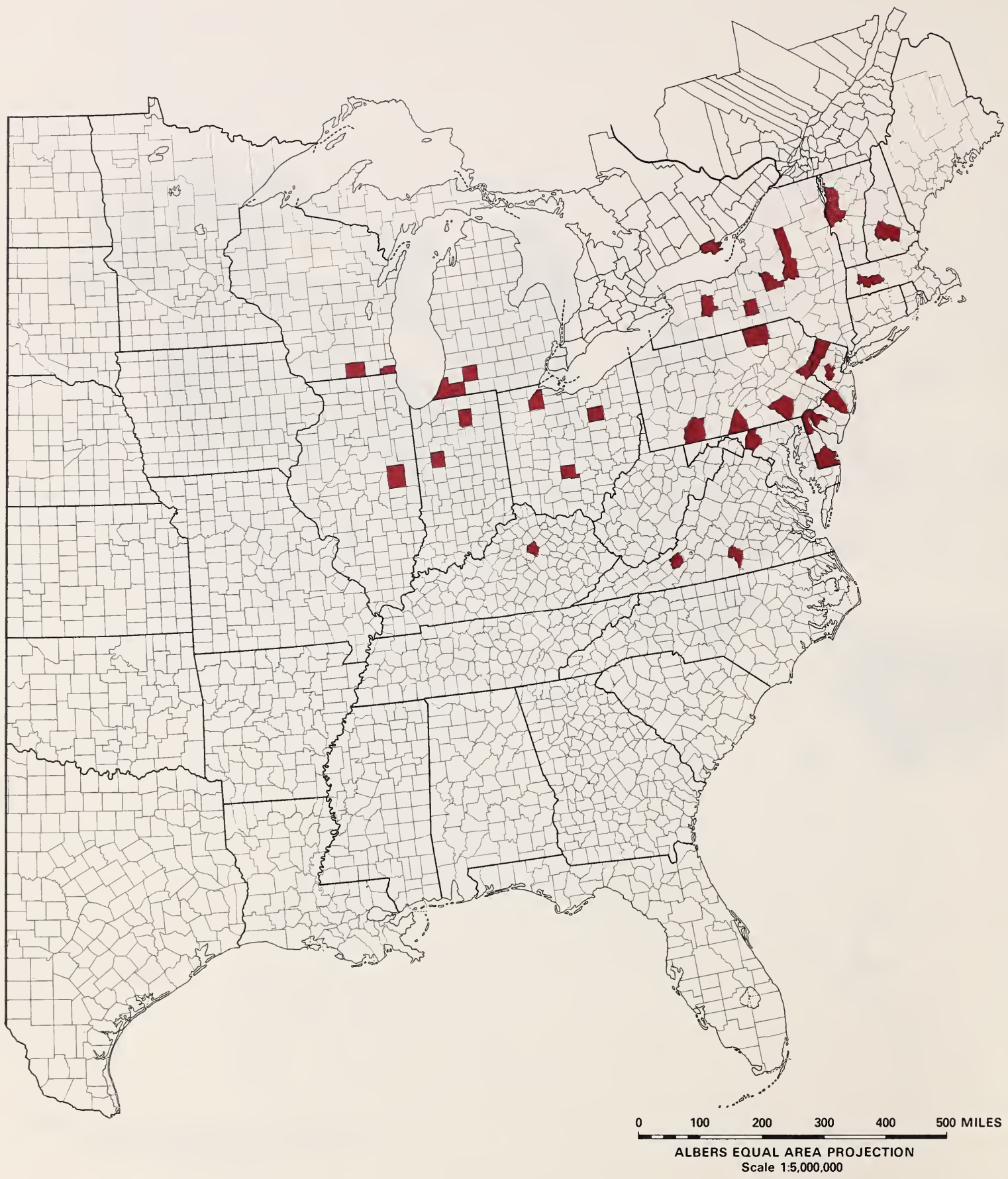




\section{BATHYPLECTES STENOSTIGMA RECOVERIES (TABLE 1)}

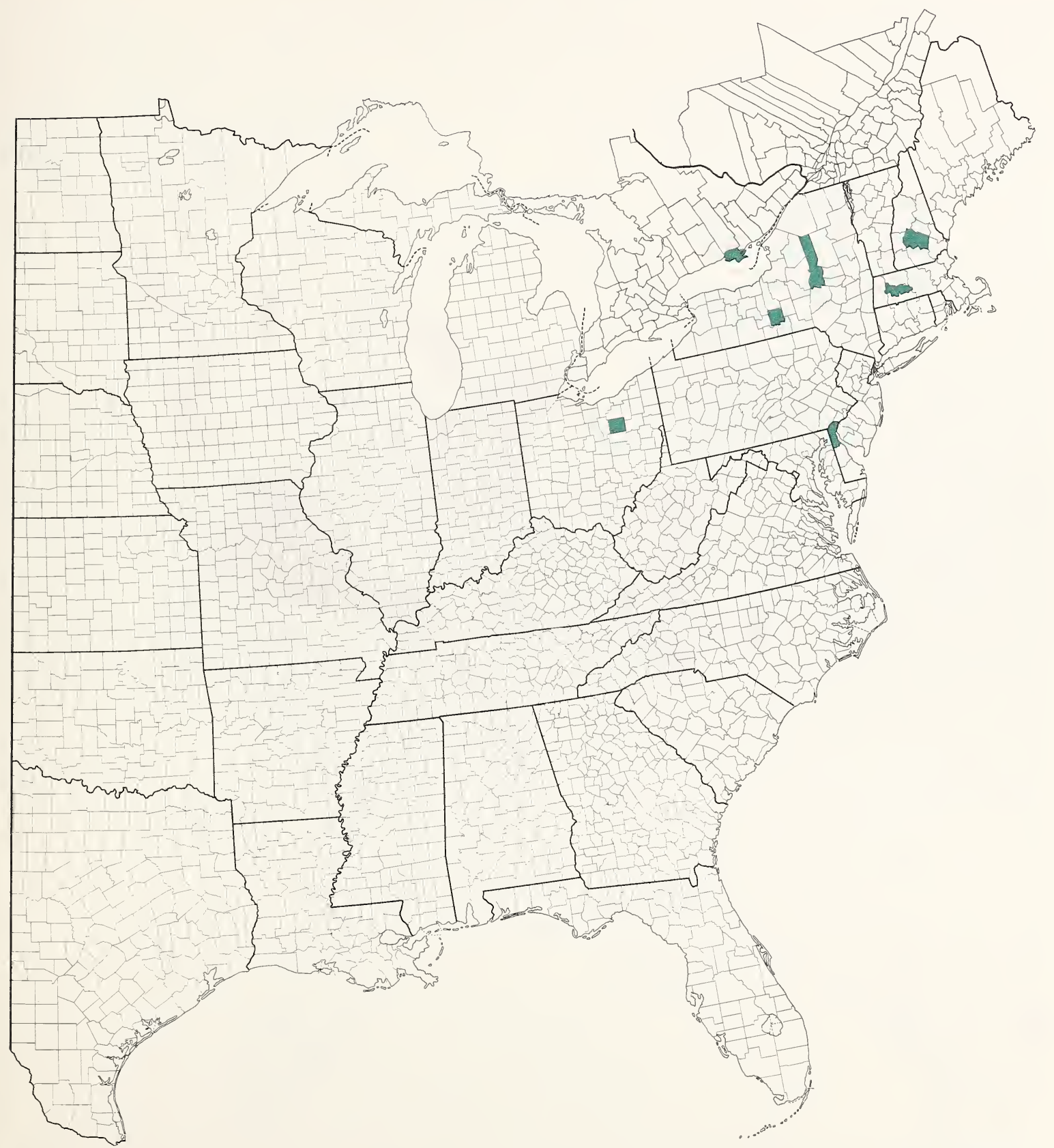




\section{TETRASTICHUS INCERTUS}

MAP 8 RELEASES (TABLE 1)

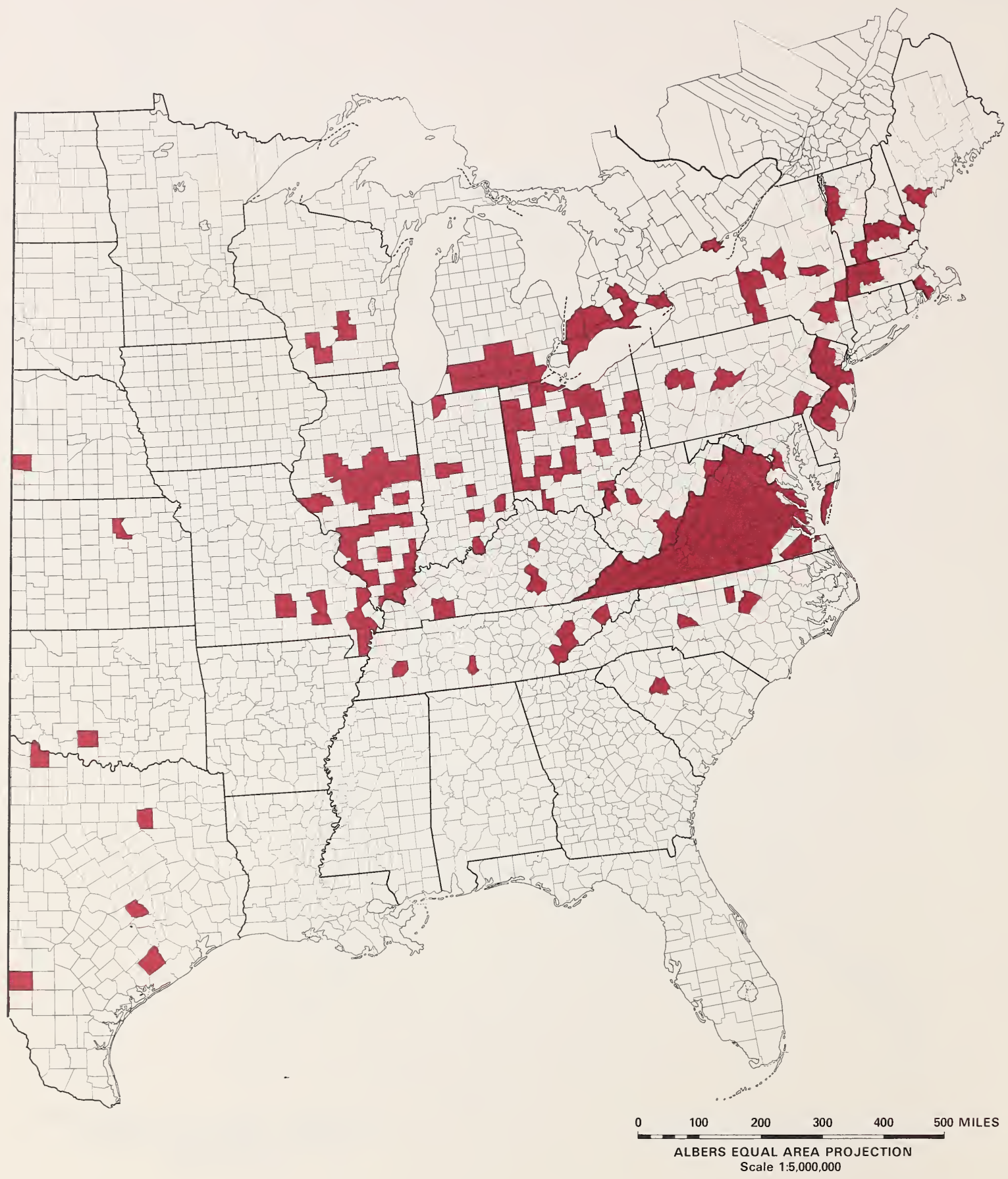


RELEASE AND RECOVERY OF INTRODUCED PARASITES OF THE ALFALFA WEEVIL 51

\section{TETRASTICHUS INCERTUS RECOVERIES (TABLE 1)}

MAP 9

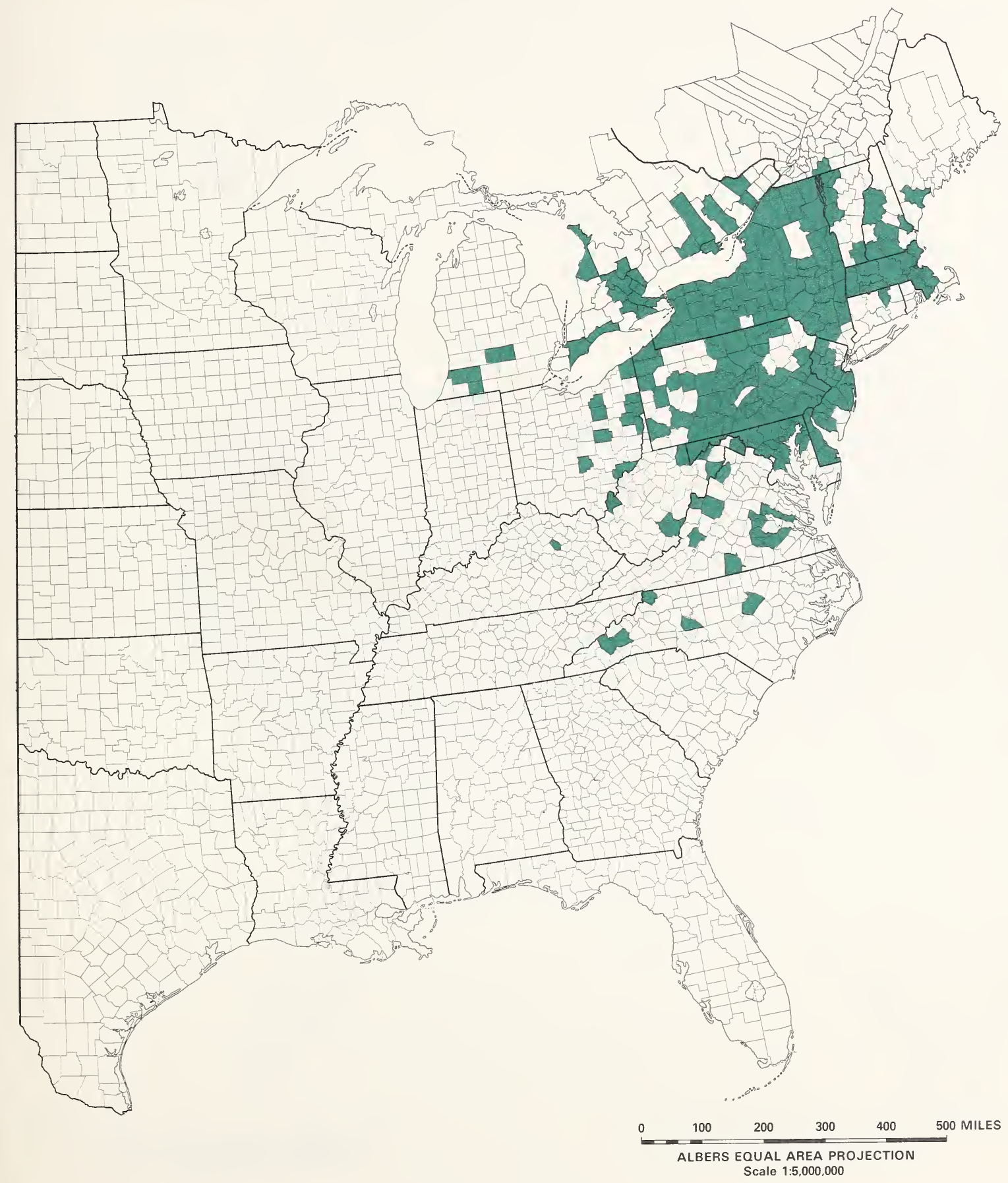


MICROCTONUS COLESI

RELEASES (TABLE 1)

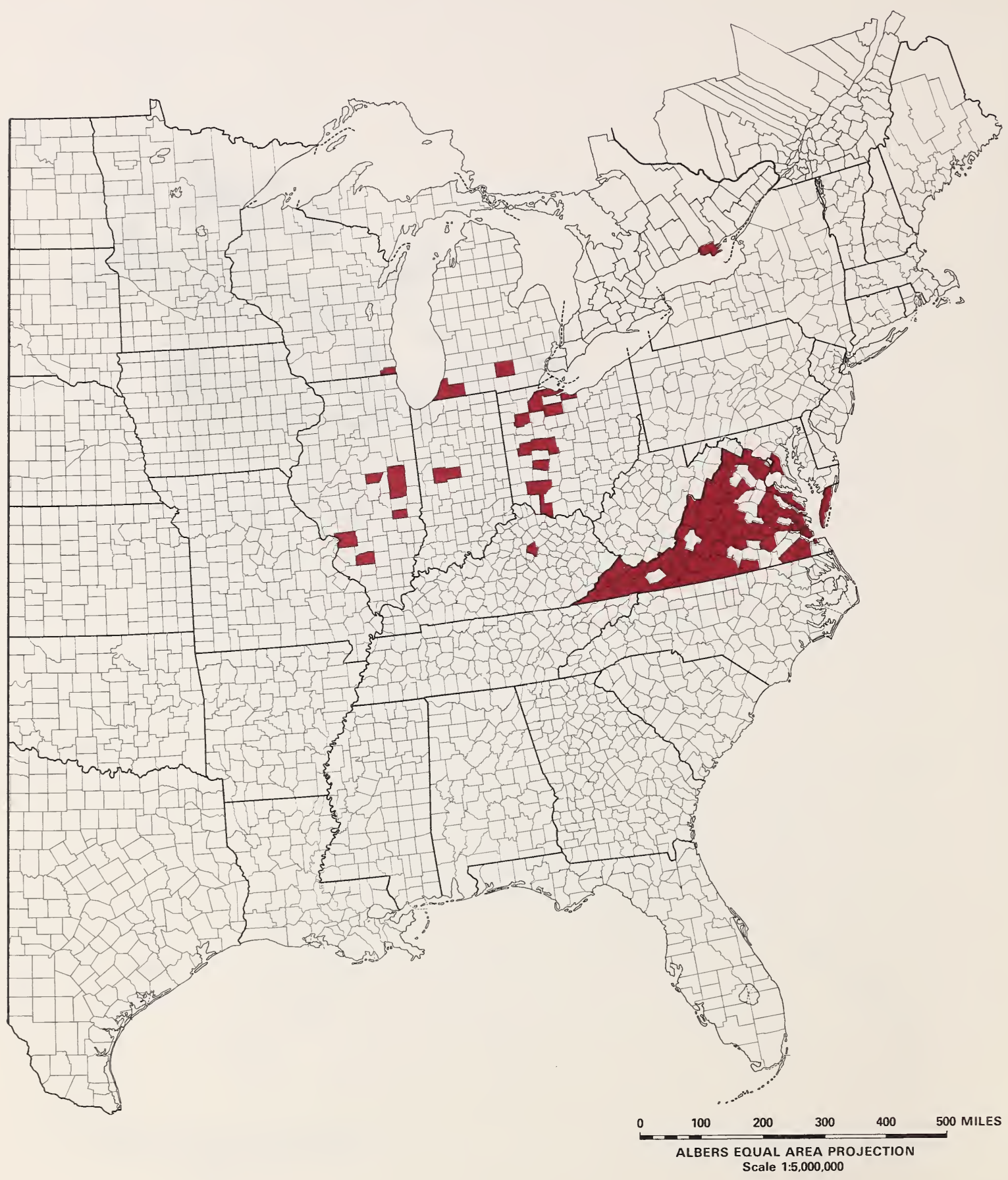


RELEASE AND RECOVERY OF INTRODUCED PARASITES OF THE ALFALFA WEEVIL

\section{MICROCTONUS COLESI RECOVERIES (TABLE 1)}

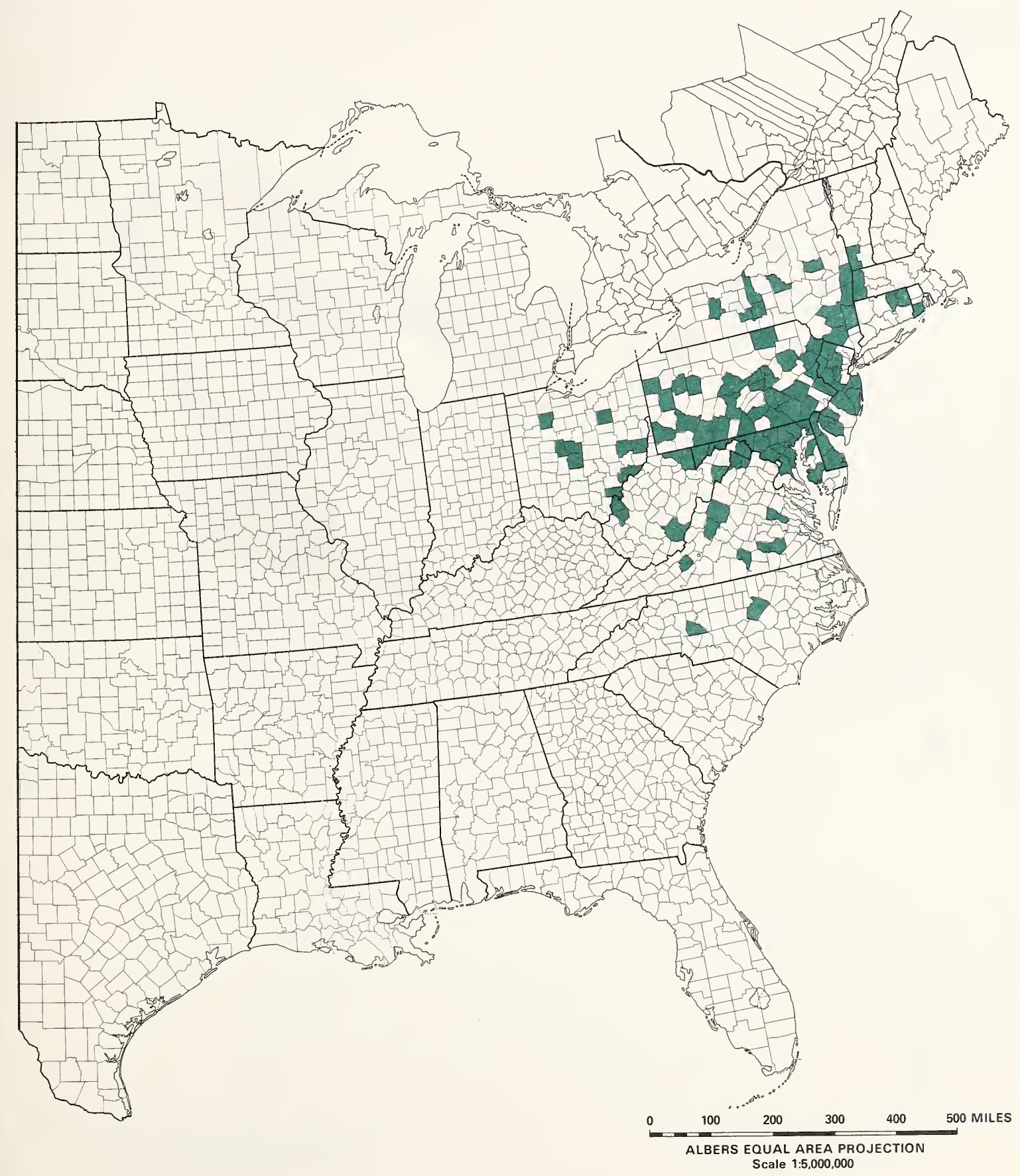




\section{MICROCTONUS AETHIOPOIDES RELEASES (TABLE 1)}

MAP 12

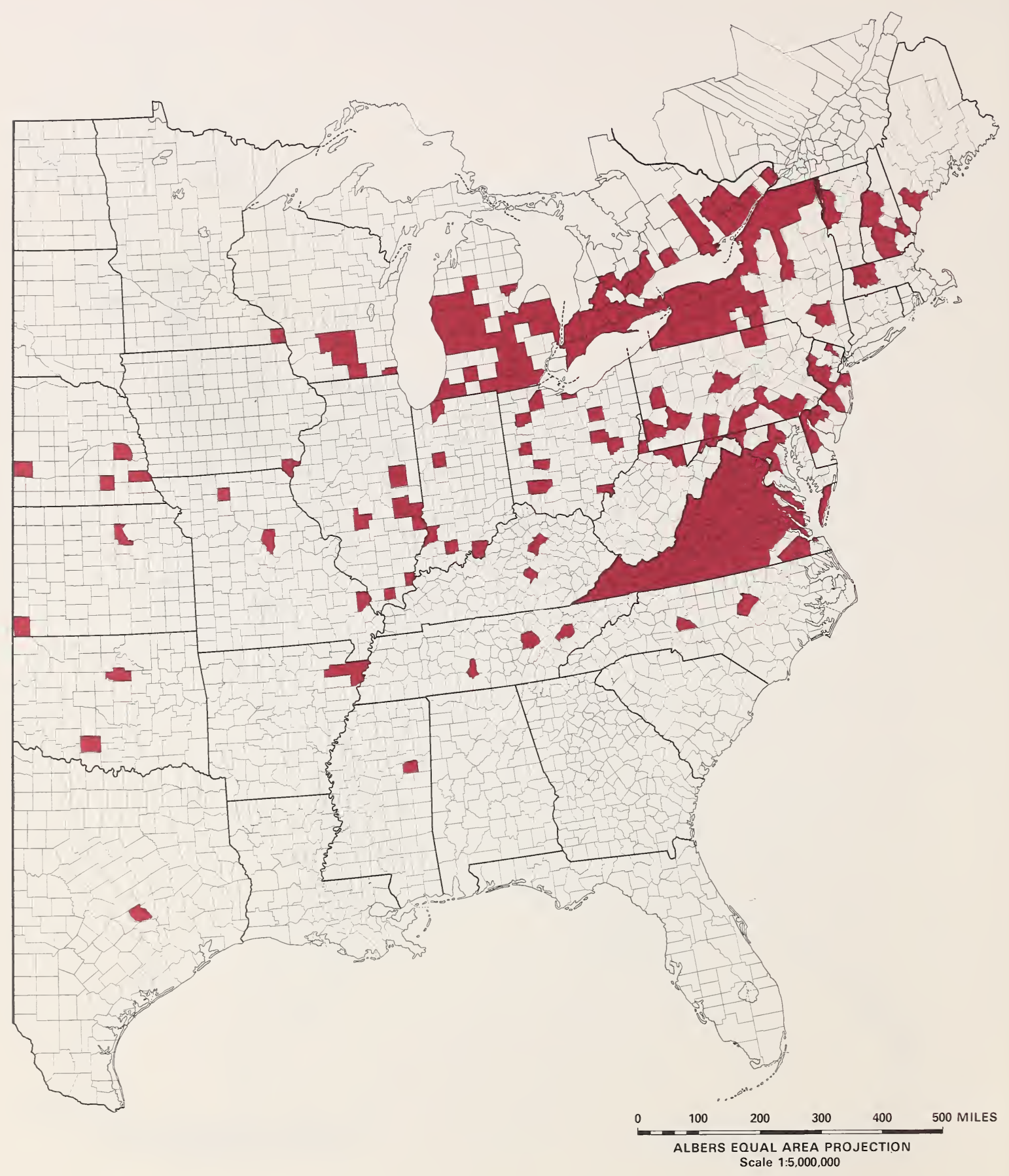




\section{MICROCTONUS AETHIOPOIDES RECOVERIES (TABLE 1)}

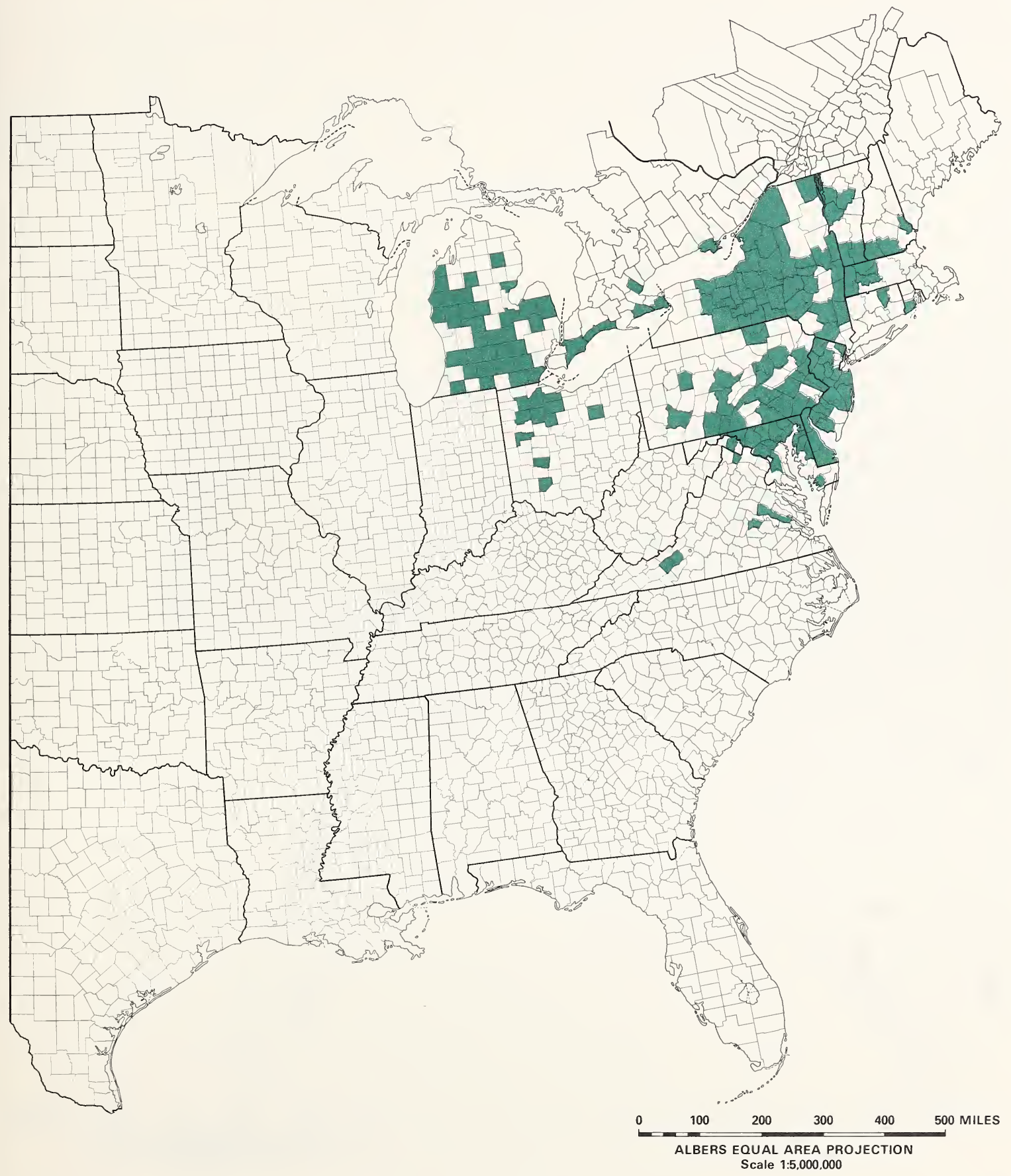


PERIDESMIA DISCUS

MAP 14 RELEASES (TABLE 2)

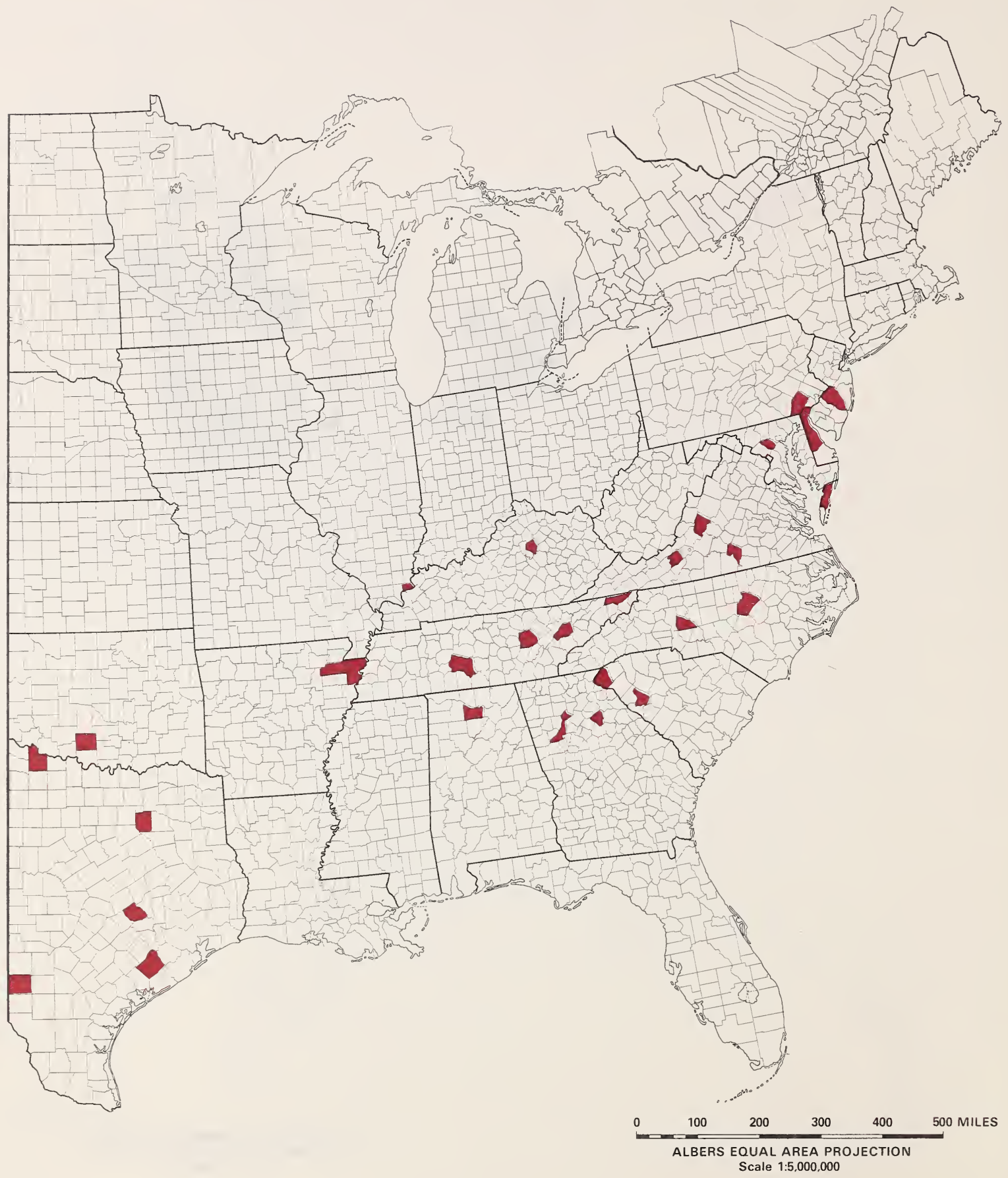




\section{TRICHOMALUS INOPS RELEASES (TABLE 2)}

MAP 15

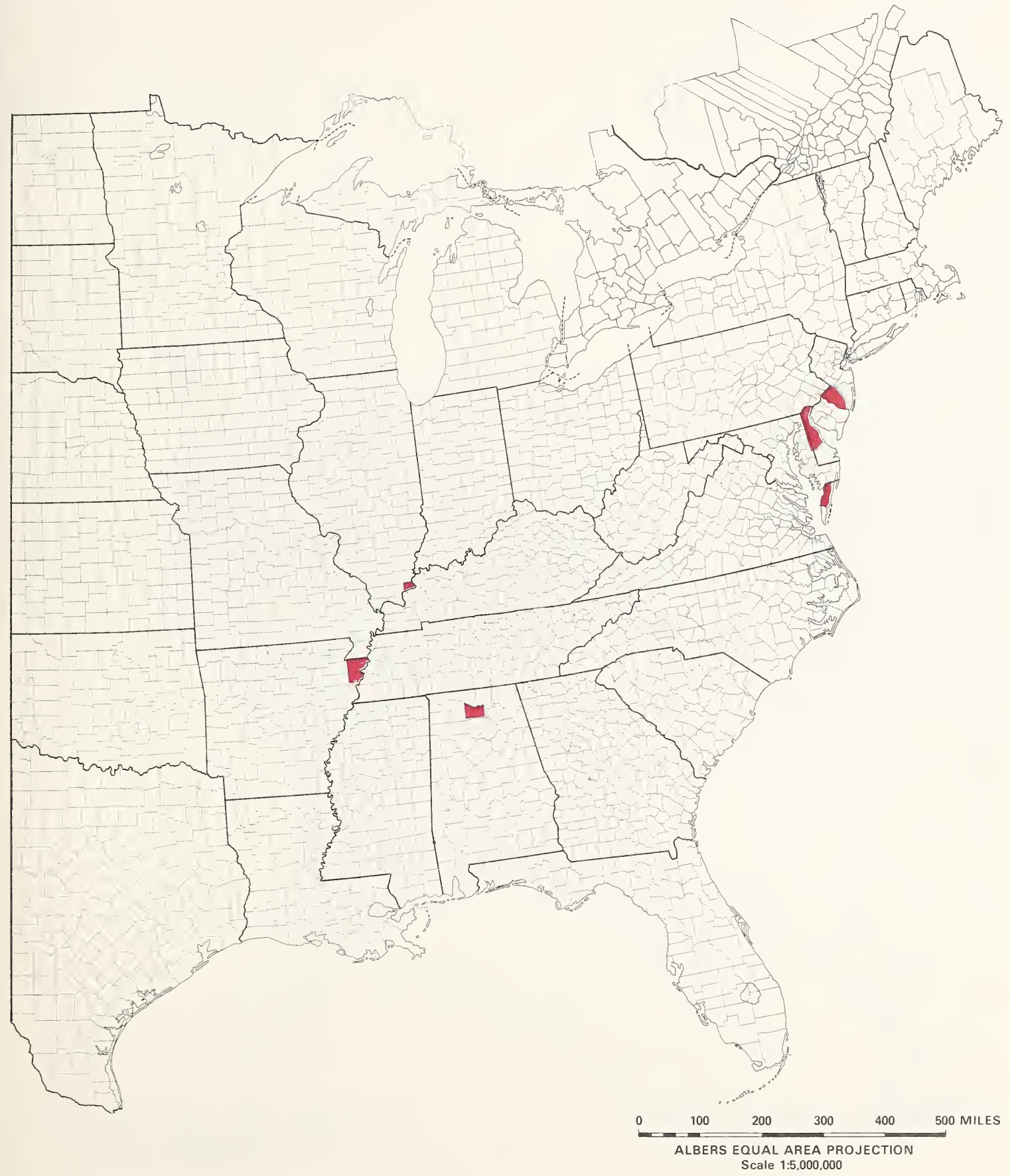




\section{DIBRACHOIDES DYNASTES RELEASES (TABLE 2)}

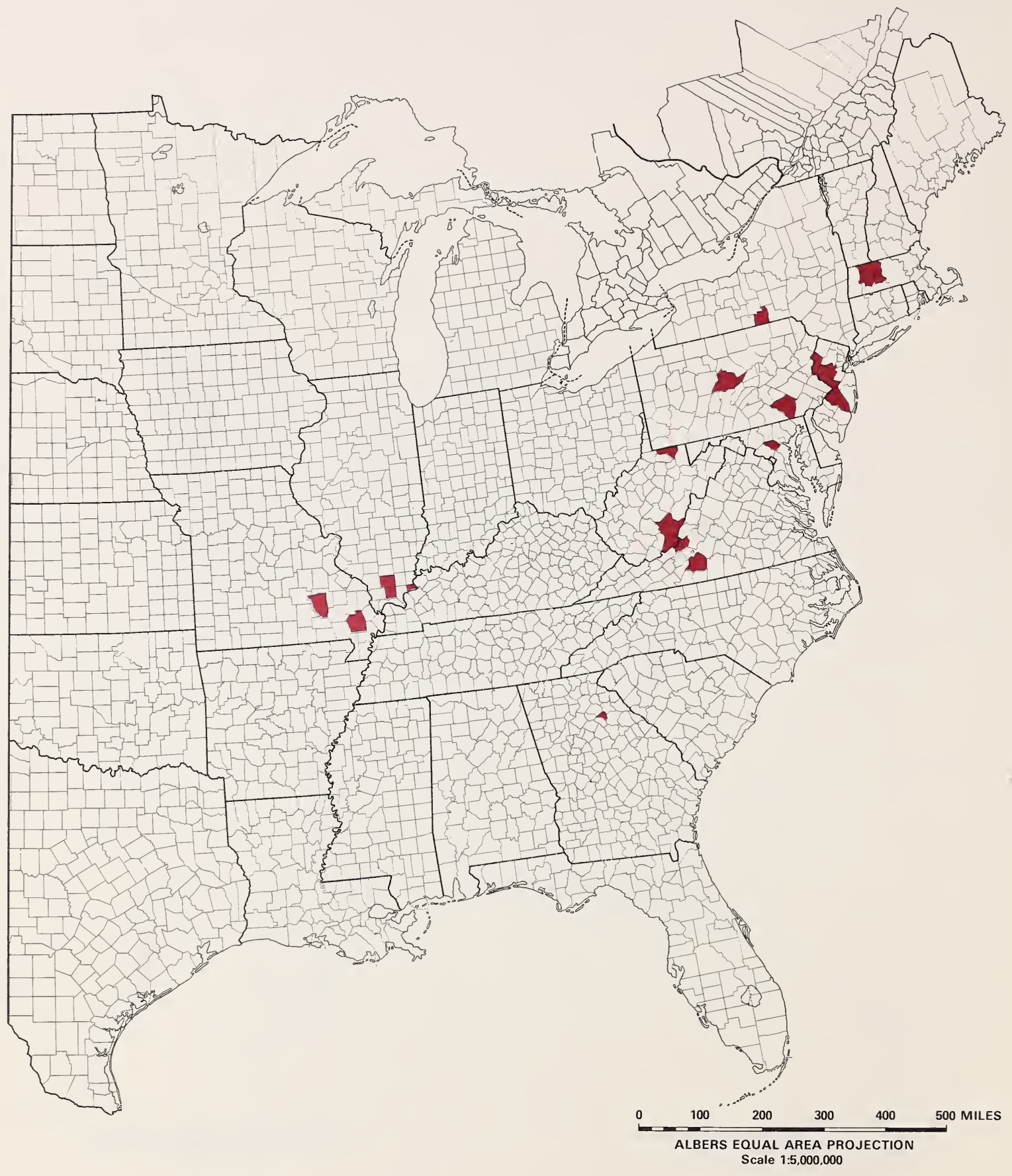


RELEASE AND RECOVERY OF INTRODUCED PARASITES OF THE ALFALFA WEEVIL 59

\section{NECREMNUS LEUCARTHROS RELEASES (TABLE 2)}

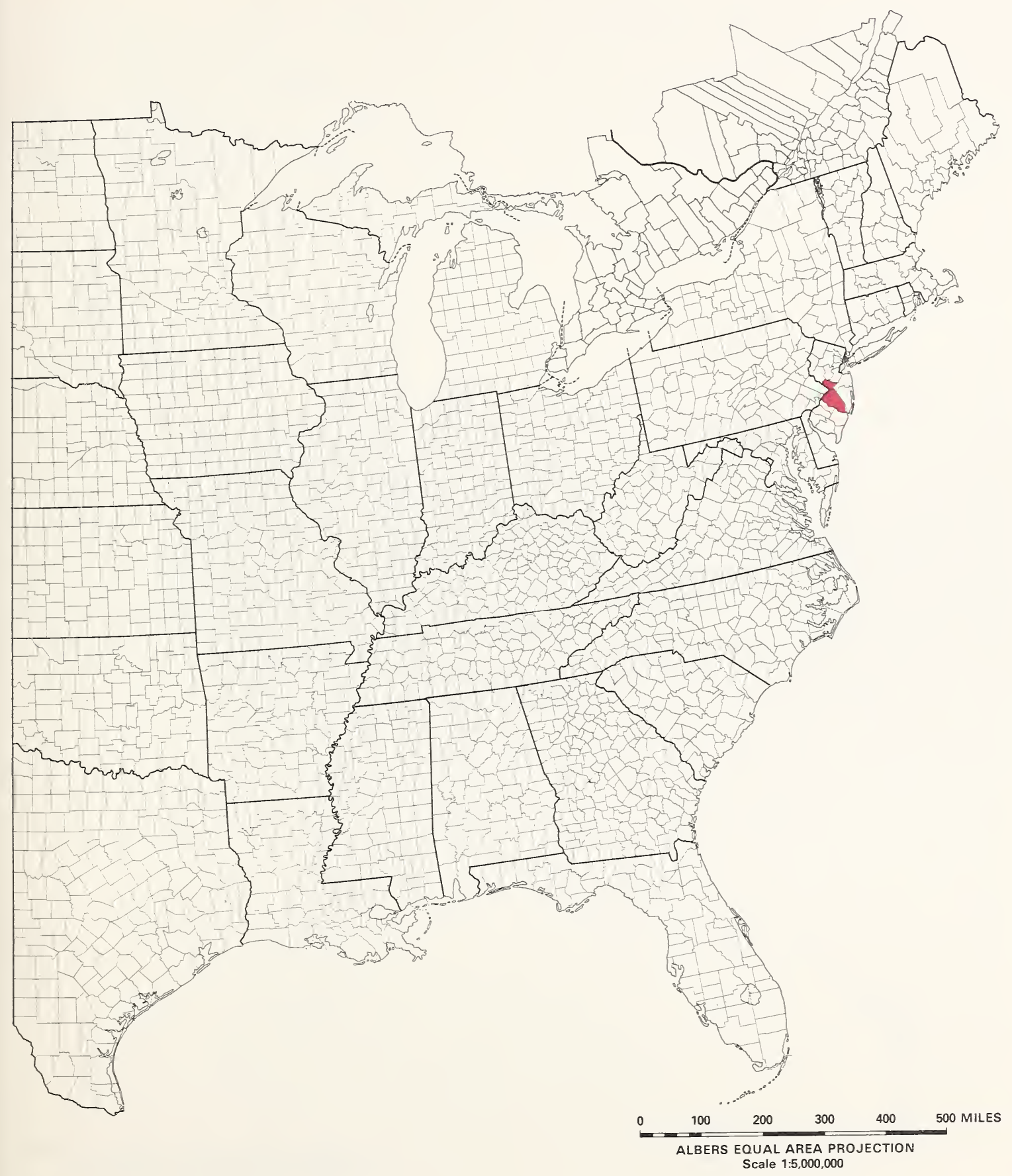




\section{CAMPOGASTER EXIGUA RELEASES (TABLE 2)}

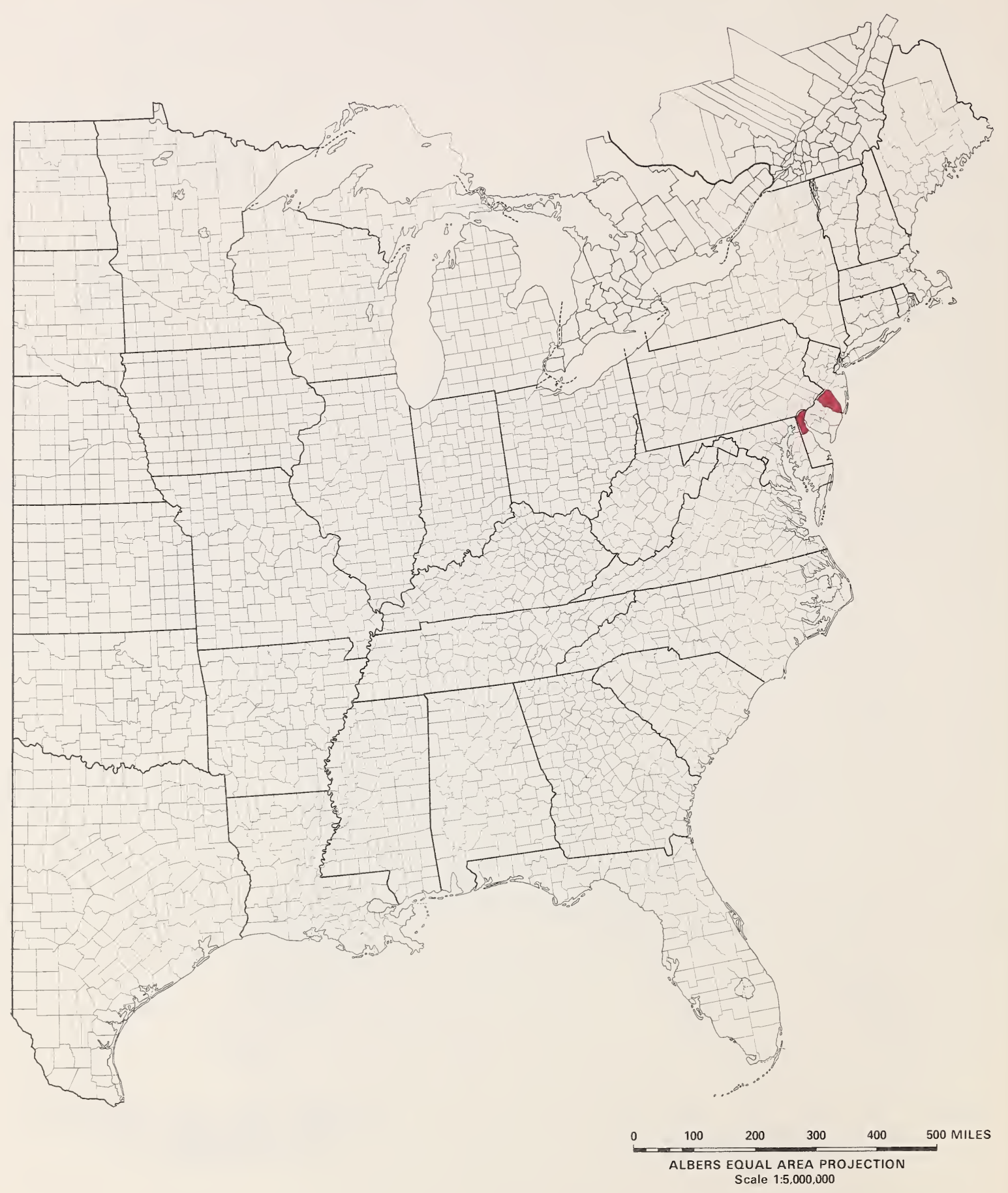


RELEASE AND RECOVERY OF INTRODUCED PARASITES OF THE ALFALFA WEEVIL

61

\section{MICROCTONUS STELLERI RELEASES (TABLE 2)}

MAP 19

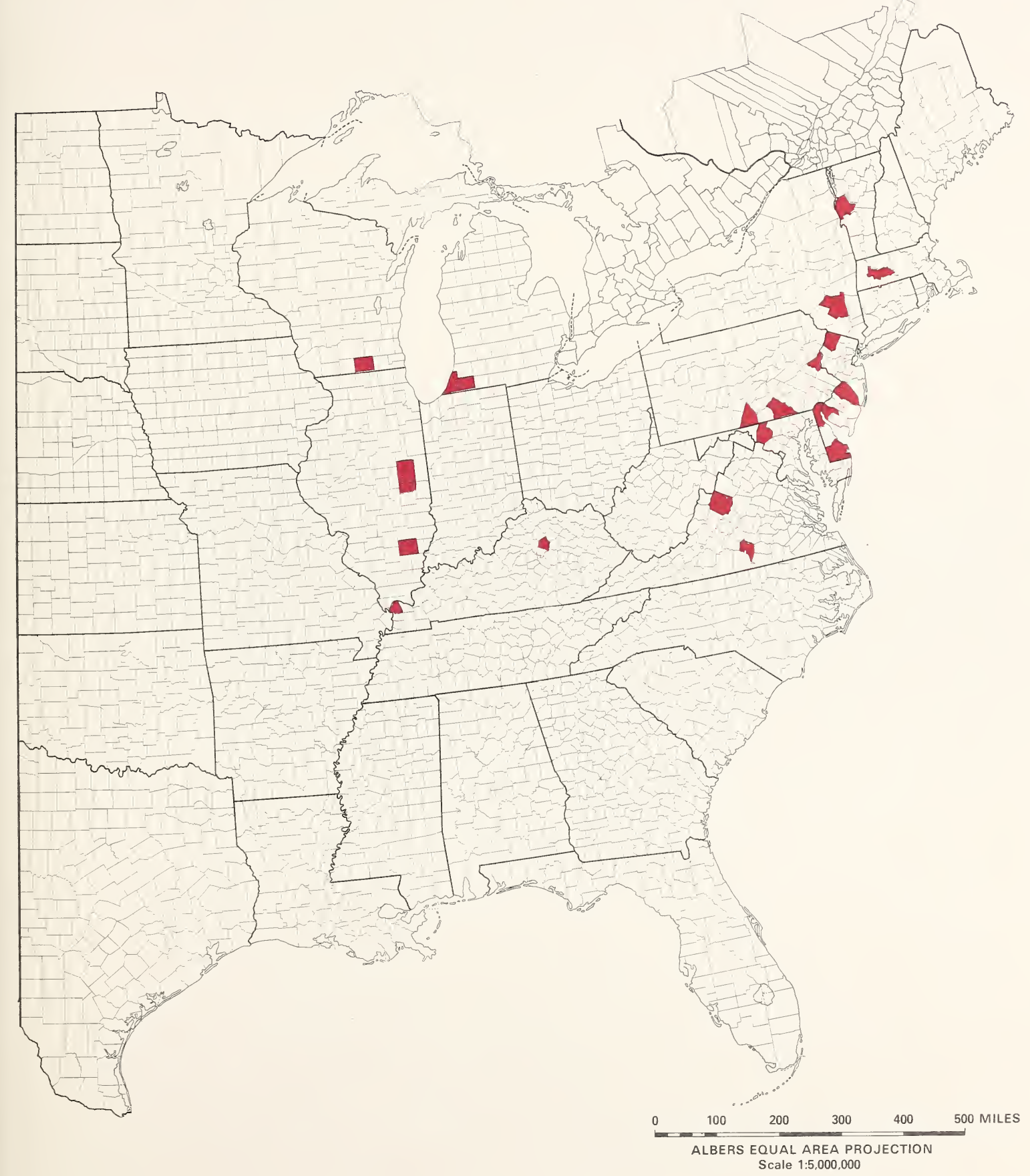




U. S. DEPARTMENT OF AGRICULTURE AGRICULTURAL RESEARCH SERVICE

HYATTSVILLE, MARYLAND 20782

POSTAGE AND FEES PAID

OFFICIAL BUSINESS

PENALTY FOR PRIVATE USE, $\$ 300$

U. S. DEPARTMENT OF AGRICULTURE AGR 101

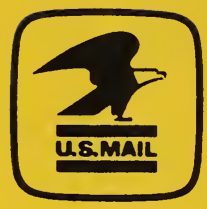

